$$
\Delta O E / S F / 10838 \text { T2 }
$$

\title{
IDENTIFICATION OF SOLID WASTES IN GEOTHERMAL OPERATIONS
}

\author{
January 1981 \\ Acurex Project 7611 \\ Contract 68-02-2611
}

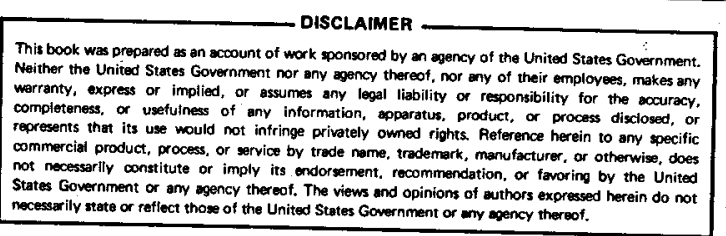

For

EPA Technical Project Monitor - Robert Hartley

Environmental Protection Agency

5555 Ridge Avenue

Cincinnati, Ohio 45268

DOE Technical Advisor - Gerald Katz

Department of Energy

1333 Broadway

Oakland, California 94612

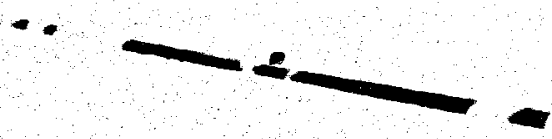

By

E. L. Hagmann, D. D. Minicucci, C. D. Wolbach

Acurex Corporation

Energy \& Environmental Division

485 Clyde Avenue

Mountain View, California 94042 


\section{DISCLAIMER}

This report was prepared as an account of work sponsored by an agency of the United States Government. Neither the United States Government nor any agency Thereof, nor any of their employees, makes any warranty, express or implied, or assumes any legal liability or responsibility for the accuracy, completeness, or usefulness of any information, apparatus, product, or process disclosed, or represents that its use would not infringe privately owned rights. Reference herein to any specific commercial product, process, or service by trade name, trademark, manufacturer, or otherwise does not necessarily constitute or imply its endorsement, recommendation, or favoring by the United States Government or any agency thereof. The views and opinions of authors expressed herein do not necessarily state or reflect those of the United States Government or any agency thereof. 


\section{DISCLAIMER}

Portions of this document may be illegible in electronic image products. Images are produced from the best available original document. 


$$
\text { DOE/SF/1083 8-T.T2 }
$$

Acurex final Report $30-70 / \mathrm{EE}$

IDENTIF ICATION OF SOLID WASTES IN GEOTHERMAL OPERATIONS

For

EPA Technical Project Monitor -- Robert Hartley

Environmental Protection Agency

5555 Ridge Avenue

Cincinnati, Ohio 45268

OOE Technical Advisor - Gerald Katz

Department of Energy

1333 Broadway

Oakland, California 94612

By

E. L. Hagmann, D. D. Minicucci and C. D. Wolbach Acurex Corporation

Energy \& Environmental Division

$485 \mathrm{Clyde}$ Avenue

Mountain View, California 94042 


\section{OISCLAIMER}

This report has been reviewed by the Industrial Environmental Research Laboratory-Cincinnati (IERL-Ci), U.S. Environmental Protection Agency (EPA), and approved for publication. Approval does not signify that the contents necessarily reflect the views and policies of EPA, nor does mention of trade names or commercial products constitute endorsement or recommendation for use. 
FOREWORD

When energy and material resources are extracted, processed, converted, and used, the related pollutional impacts on our environment and even on our health of ten require that new and increasingly more efficient pollution control methods be used. IERL-Ci assists in developing and demonstrating new and improved methodologies that will meet these needs both efficiently and economicilly.

This report documents a recently cimpleted project. The purpose of this work was to assess the potential hazardous characteristics of geothermal solid was tes. Samples from active geothermal resource areas were examined for corrosivity, EP toxicity, radioactivity, and bioaccumulation potential. The findings documented in this report showed that several samples could be classified as hazardous. However, these results cannot be extrapolated to other geothermal resource areas. The information contained in this report also serves as the basis for additional work. For further information, contact the Alternate Energy Sources Branch, Cincinnati, Ohio.

David G. Stephen

Director

Industrial Environmental Research Laboratory

Cincinnati, Ohio 


\section{ABSTRACT}

Regulations governing the disposal of hazardous wastes led to an assessment for geothermal solid wastes for potentially hazardous characteristics. Samples were collected from three active geothermal sites in the western United States: The Geysers, Imperial Valley, and northwestern Nevada. Approximatel y 20 samples were analyzed for corrosivity, EP toxicity, radioactivity, and bioaccumulation potential. The samples were further characterized by analys is for cations, anions, moisture content, priority pollutants, and additional trace metals in the leachate. In addition, an aqueous extraction was conducted at ambient pH. None of the samples collected at The Geysers or northwestern Nevada could be classified as hazardous as defined by the RCRA regulations published May 19, 1980 in the Federal Register. However, several samples from the Imperial Valley could be classified as hazardous. These hazardous characteristics appear to be related to the high salinity of geothermal fluids in that order.

This study characterized samples from a limited geographical area and results cannot be extrapolated to other geothermal resource areas. 
PROJECT OVERVIEW ................ 1- 1

1.1 Introduction ................ 1-1

1.1 .1 Background . ................. $1-2$

1.1 .2 objectives ............... 1-... $1-2$

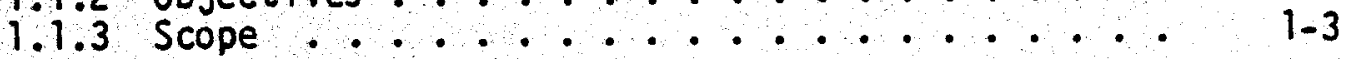

1.2 Results ........................ $1-4$

1.2.1 Sampling Site Survey ............ 1-4

1.2.2 Field Sampling Program . ....... 1-. $1-4$

1.2 .3 Analytical findings ....... $1-5$

1.2.4 Conclusions and Recommendations . . . . $\quad 1-7$

2 SAMPLING PROGRAM ..................... $2-1$

2.1 Selection of Sampling Sites .......... 2-1

2.2 Gener al Sampling Methods .......... 2-4

2.2.1 Sampling Protocols ............ 2- 2-6

2.2 .2 Field Equipment .... . . . . . . . 2.7

2.2.3 Sample Preservation ........... 2-8

2.3 Identification of Samples Collected ...... 2-8

2.4 Method Development Needs .......... 2-11

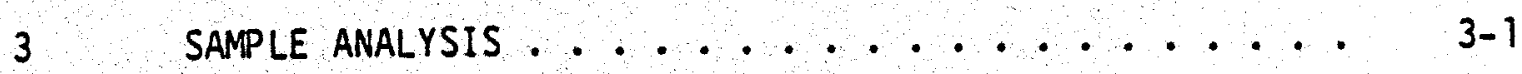

3.1 General Analytical Approach ......... 3-1

3.1.1 Background .................. 3-1

3.1 .2 Analytical Scheme ............ $3-4$

3.1.3 Analytical Detection Limits ........ 3-7

3.2 Selection of Samples for Analysis ........ 3-8

3.3 Analytical Results ............. 3-12

3.3.1 Corrosivity ................ $3-12$

3.3.2 Radioactivity ............. $3-12$

3.3.3 EP Toxicity .............. 3- $3-16$

3.3.4 Organics Analysis ............ 3-... 3-20

3.3.5 Bulk Composition . . . . . . . . 3-21

3.4 Quality Control . . . . . . . . . $3-21$

3.4.1 General Quality Assurance/Quality Control ... 3-21

3.4.2 Program Specific Quality Control...... 3-25 
Section

Page

3.5 Method Development Needs . . . . . . . . $3-29$

3.5.1 Analytical Procedure for Boron .........

3.5.2 Analytical Procedure for Sulfide . . . . . 3-29

3.5.3 Extraction Procedure ............. 3- 29

3.5.4 Brines Vs. Extracts ............ 3-30

3.5.5 Moisture Content ............ 3-30

4 RESULTS DISCUSSION $\ldots \ldots \ldots \ldots \ldots \ldots \ldots-1$

4.1 RCRA Hazardous Waste Regulations . . . . . . 4-1

4.2 Geothermal Resource Area . . . . . . . 4 4 4

4.3 Acid Versus Ambient pH Extraction . . . . 4-5

APPENDIX A - LETTER REQUESTING PERMISSION TO SAMPLE $\quad A-1$

APPENDIX B - SAMPLING TRIPS \& $\ldots$. $\ldots-1$

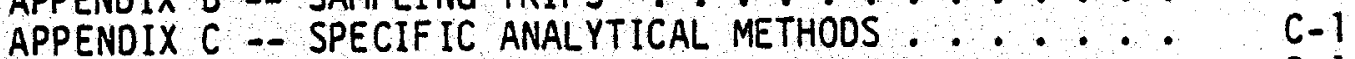

APPENDIX 0 - ANALYTICAL OATA REPORTING SHEETS $\cdots \cdots \quad D-1$

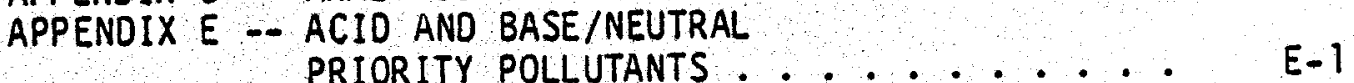




\section{LIST OF TABLES}

Table

Page

$1-1$

Comparison of Analytical Results with RCRA Criteria

for Hazardous Was tes

$1-6$

1-2 Summary of Results for Additional Metals _ . . . $\quad 1-8$

Approved Sites for Collecting Samples ........

$2-5$

$2-2$

Results of Geothermal Field Sampling Program .....

$2-9$

3-1 Priority Listing of Samples for Analysis . . . . . 3-9

3-2 Final Selection of Samples for Analys is . . . . 3-11

3-3 Key to Identifying Samples ............. 3-13

3-4 Corrosivity in Order of Increasing pH . . . . . 3-14

3-5 Radium 226 in Order of Increasing Activity . . . . 3-15

3-6 RCRA Trace Elements in Order of Decreasing Total Trace Elements (mg/1) in Acid Extract . . . . . 3-17

3-7 Additional Metals in Order of Decreasing Total Trace Elements (mg/l) in Acid Extract . . . . . . 3-18

3-8 Alternate Methods Employed in the Extraction Procedure...................... 3-19

3-9 Organics Analysis Results . . . . . . . . $\ldots$.

3-10 Bulk Composition of Total Sample (Decreasing Weight $\%$ Silica) and Tentative Identification of Major Components

3-11 Bulk Composition Extracts in Decreasing Chloride Content (mg/L)

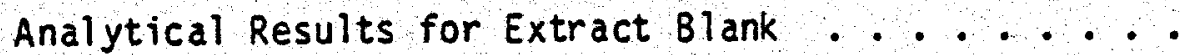

4-1 Comparison of Analytical Results with RCRA Criteria

4-2 Comparison of Geothermal Resource Areas for RCRA 


\section{ACKNOWLEDGMENT}

Acurex gratefully acknowledges the technical support and guidance received from Mr. Robert Hartley, Project Officer, Industrial Environmental Research Laboratory in Cincinnati, Ohio, and Mr. Gerald Katz, Coproject officer, Department of Energy in Oak Iand, California. Acurex also wishes to acknowledge the contributions of the individuals responsible for geothermal activities at each resource area who allowed us to collect samples from the ir facilities. 


\section{SECTION 1}

PROJECT OVERVIEW

\subsection{INTRODUCTION}

Under contract to the U.S. Environmental Protection Agency (EPA), Industrial Environmental Research Laboratory in Cincinnati, Ohio, Acurex Corporation is preliminarily determining the hazardous nature of solid wastes resulting from the extraction and processing of geothermal energy resources. This project is being cosponsored by the U.S Department of Energy (DOE), Geothermal Energy Division in Oakland, California. The purpose of this study has been to collect information in a manner sufficient to allow the design and scoping of a comprehensive and detailed project to establish whether geothermal solid wastes pose any hazardous waste management concerns.

Our work has included the following major elements:

- Surveying geothermal development sites to identify suitable solid waste streams and obtain permission to collect samples

- Conducting field sampling trips to sites in the Imperial Valley, The Geysers, and northwestern Nevada

- Analyzing approximately 20 samples to identify potentially hazardous constituents and characterize the chemical composition of the solids

The findings of our study are documented in this report. Section 1 provides an overview of the project including this introduction and a 
presentation of results. The field sampling program is described in Section 2. Analytical methods and results are presented in section 3. A discussion of the analytical results is provided in section 4.

\subsubsection{Background}

The Resource Conservation and Recovery Act of 1976 (RCRA) requires that EPA promulgate regulations for the handling and disposal of solid wastes, including those containing hazardous substances. As part of its obligations under RCRA, EPA is examining the hazardous potential of various solid wastes such as those arising from geothermal activities to determine under what sections of RCRA these should be controlled.

On December 18, 1978, EPA proposed the initial set of RCRA regulations for managing hazardous solid wastes. The cornerstone of these regulations was the Agency guidance on how to determine whether a solid waste is hazardous. Candidate character istics were introduced which formed the bas is for identifying hazardous wastes. of these, four were potentially applicable to solid wastes produced by geothermal energy development operations: corrosivity, toxicity, radioactivity and bioaccumulation potential. In anticipation of Congressional action to exclude geotherma 1 was tes from the RCRA hazardous was te management regulations while requiring that studies be undertaken to define the nature of these wastes, EPA has initiated a research program to evaluate geothermal solid was te against these hazardous was te character istics.

\subsection{2 objectives}

The objectives of this project are:

- To sample and analyze solid wastes representing a broad spectrum of geothermal resource areas and types of exploration and development activities 
- To preliminarily determine via the RCRA analytical protocols whether such solid wastes meet the criteria for being hazardous

\section{1 .3 Scope}

The scope of this project was dictated by its role as a screening study to provide preliminary data and help focus the efforts of a comprehensive project to examine geothermal solid wastes. The number of samples analyzed was limited to approximately 20 .

As recommended by EPA's Office of Solid Waste, the draft final report, "Field and Laboratory Sampling and Analys is Manual for the Presurvey of Solid Was te Management Practices in the Mining Industry," prepared by PEDCo Environmental for EPA/IERL-Ci, January 1980, was used for protocol guidance in the field sampling program.

The analytical protocols specified in the proposed RCRA regulations of December 18, 1978 (Title 40, Code of Federal Regulations Part 250, cited at Federal Register Volume 43 , Number 243, p. 58946) were followed with the addition of an ambient pH extraction procedure (EP) using deionized water. Ouring the course of the project, EPA promulgated final regulations for the hazardous waste identification portion of the RCRA hazardous was te management program proposed in 1978 (Title 40 , Code of Federal Regulations Part 261 , cited at Federal Register, Volume 45 , Number 98, p. 33119, May 19, 1980). The analytical protocols employed in this study reflect the proposed regulations. These were not significantly al tered by the May 19, 1980 promulgation. The results, however, are compared with the final regulations for the purpose of determining the hazardous nature of the solid was tes. 


\subsection{RESULTS}

A sumary of the results for the following major tasks of this study are presented below:

- Survey to identify sampling sites

- Field sampling program

- Analytical findings.

\subsubsection{Sampling Site Survey}

Major geothermal resource exploration and development sites in the western United States and the Gulf Coast were preliminarily screened to locate candidate sites for obtaining solid waste samples. A telephone survey of over 20 individuals representing 15 organizations was conducted to identify the types of solid wastes generated and procedures necessary to obtain permission to sample.

As a result of the telephone discussions, follow-up letters, and several site visits, the sampling program was defined and permission granted for collecting samples in three geothermal resource areas (GRA's):

- Imperial Valley - 7 sites

- The Geysers - 11 sites

- Northwestern Nevada - 3 sites

\subsubsection{Field Sampling Program}

The geothermal sampling progran consisted of three field trips:

\begin{tabular}{|c|c|c|}
\hline Resource Area & Sampling Dates & No. of Samples collected \\
\hline $\begin{array}{l}\text { Imperial valley } \\
\text { The Geysers } \\
\text { Nevada }\end{array}$ & $\begin{array}{l}\text { May } 20-23,1980 \\
\text { June } 3-5,1980 \\
\text { July } 1-2,1980\end{array}$ & $\begin{array}{l}16 \\
13 \\
4 \\
\end{array}$ \\
\hline
\end{tabular}


The 33 samples collected were comprised of the following types:

Drilling sumps

Mud/fluid $\quad 8$

Mud only 3

Fluid only 5

Preinjection treatment

Sediment ponds $\quad 3$

Flash tank 1

Filter press 1

Cooling tower basins $\quad 3$

$\mathrm{H}_{2} \mathrm{~S}$ removal

Centrifuge (iron sulfide 3

sludge dewatering)

Stretford process 1 .

sulfur recovery stream

Miscellaneous

Pipe scale $\quad 2$

Geological surface 1

expression

Landfills

2

\subsubsection{Analytical Findings}

The focus of the sample analys is program was to evaluate solid was tes in comparison to the RCRA hazardous was te characteristics. Results of this effort are presented in Table 1-1.

of the 20 samples collected which were selected for analysis, only five exhibited corrosivity, radioactivity, toxicity, or bioaccumulation values which exceed the proposed (for radioactivity and bioaccumulation) or the promulgated (for corrosivity and toxicity) RCRA criteria for being considered hazardous solid wastes. The two samples (G:10 and G14) which exceeded the maximum concentrations for the EP toxicity metals are both geothermal brines collected at wells in the northern portion of the 
Table 1-1. Comparison of Anal yt ical Results with RCRA Criteria for Hazardous Wastes

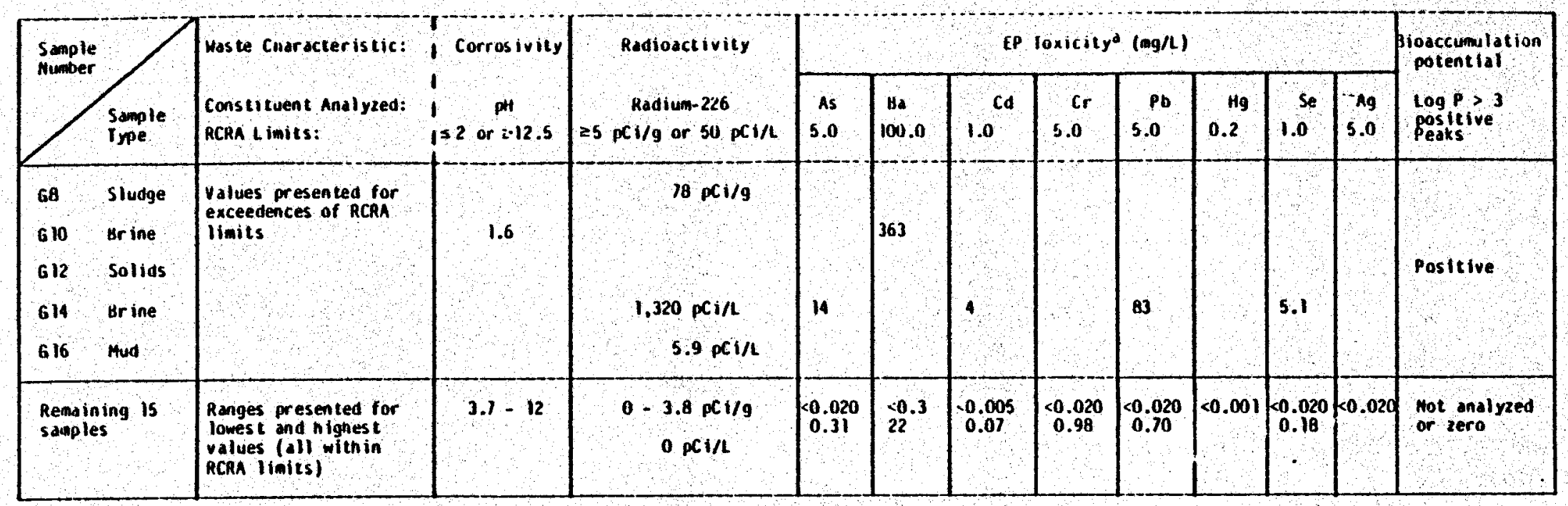

acia extracts and liquid sample filtrate 
Imperial Valley. Under current regulations in force in this GRA, brines such as these are routinely disposed of in State hazardous waste disposal sites.

In addition to the eight metals cited under the RCRA EP toxicity characteristic, eight additional metals were analyzed in this study. These were included because of their suspected presence in geothermal solid wastes and their listing in the water quality standards of several western states. Analytical results for these metals are sumarized in Table 1-2.

Additional organic analyses were conducted on three samples. The EP extracts were solvent extracted and the acid and base/neutral fractions analyzed for a total of 57 organic compounds by GC/MS. The solvent extracts were also tes ted for bioaccumulation potential using the HPLC procedure specified in the proposed RCRA regulations of December 18, 1978. One sample showed a positive bioaccumulation potential.

\subsubsection{Conslusions and Recommendations}

Samples of solid wastes were obtained from the Geysers geothermal powerplant in northern California, from several of the geothermal exploration and development sites in the Imperial valley of southern California, and from a few exploration sites in northern Nevada. The conclusions and recommendations from the limited sampling and analys is effort are presented below.

\section{CONCLUSIONS}

1. None of the samples of waste materials collected at the commercial power plant operations in The Geysers geothermal steam fields and 
Table 1-2. Summary of Results for Additional Metals a

\begin{tabular}{|c|c|c|c|}
\hline Metal & $\begin{array}{l}\text { Range of } \\
\text { Concentrations } \\
\text { - All Samples } \\
\text { (mg/L) }\end{array}$ & $\begin{array}{l}\text { Average Concen- } \\
\text { tration - Al1 } \\
\text { Values Above } \\
\text { Detection Limit } \\
\text { (mg } / L \text { ) }\end{array}$ & $\begin{array}{l}\text { Number of } \\
\text { Values Above } \\
\text { Detection Limitb }\end{array}$ \\
\hline Antimony & $<0.05-0.18$ & 0.14 & 3 \\
\hline Beryllium & $<0.020$ & - & 0 \\
\hline Boron & $<0.2-660$ & 43 & 26 \\
\hline Copper & $<0.05-60$ & 9 & 12 \\
\hline Lithium & $<0.05-5.8$ & 1.1 & 19 \\
\hline Nickel & $<0.2-0.90$ & 0.50 & 11 \\
\hline Strontium & $<0.5-1400$ & 174 & 16 \\
\hline$Z$ inc & $<0.020-6000$ & 203 & 30 \\
\hline
\end{tabular}

aIncludes results for both acid and amb ient pH extracts

bTotal number of possible values (analyses) equals 42 
at the northern Nevada exploration sites could be classified as hazardous as defined by the criteria in the Hazardous Was te regulations published May 19, 1980 in the Federal Register.

2. Several samples including brines, drilling wastes, and settling pond solids from geothermal exploration and development sites in the Imperial valley could be class ified as hazardous was te, with character istics exceeding the Hazardous Waste criteria in one or more of the categories of $\mathrm{pH}$, radioactivity, EP toxicity, and bioaccumulation.

3. The principal source of the hazardous characteristics in the Imperial Valley is the geothermal brine itself. Imperial Valley brines generally have considerably higher salinities than do geothermal fluids elsewhere. Hazardous waste characteristics appear to be directly related to salinity.

4. Since salinity is site-dependent, it can be concluded that the hazardous was te character or geothermal solid wastes will be site dependent.

5. Higher heavy metal concentrations were always associated with low ambient pH, but low pH did not guar antee high heavy metal content.

6. High radioactivity (Radium 226) values were associated with higher metals content, but the correlation was not exhibited with lower radioactivity values.

7. The significance of the high bioaccumulation potential in one sample has not been determined. The bioaccumulating compounds were not identified. 
8. This study cannot be used to generalize as to the hazardous character of geothermal wastes outside the sites studied without considerable qualification. Each geothermal resource must be considered unique in its chemical and physical character.

\section{RECOMMENOATIONS}

1. Geothermal resources should be screened for radioactivity and pH. Samples with $\mathrm{pH}$ below 4.0 should be further screened for heavy metals. The ambient or neutral toxicity extraction procedure can be used for these low $\mathrm{pH}$ samples.

2. Bioaccumulating constituents should be determined and their source identified before bioaccumulation is a major oriteria for geothermal hazardous waste characterization.

3. In view of the requirements of the RCRA ammendments of 1980 for a comprehensive study of the characteristics and disposal or actices for geothermal solid wastes, any further research studies should be directed toward specific needs as imposed by the amendments and as further defined by EPA's Office of Solid Waste. 


\section{SECTION 2}

\section{SAMPLING PROGRAM}

\subsection{SELECTION OF SAMPLING SITES}

The process of selecting sites for sampling geothermal sol id wastes involved the following activities:

- Formulating a priority listing of desired sites

- Contacting site owners/operators to identify sampling points and requesting permission to collect samples

- Finalizing the group of sites to be visited

Based on discussions held at the beginning of the project with EPA, $D O E$, and Acurex project management, var ious geothermal developments in the United States were ranked into three groups according to their perce ived desirability as sampling sites:

Group 1 (Prime Interest)

The Geysers, California Imperial Valley, Cal ifornia

Group 2

Valles Caldera, New Mexico Roosevelt Hot Springs, Utah
Group 3 (Least Interest)

Raft River, Idaho

Beowawe, Nevada

Gulf Coast, Texas and Louis iana

Klamath Falls, Oregon

Puna, Hawaii

Other sites in the western United States

The location of these sites is illustrated in Figure $2-1$.

Rank ing criter ia for the sites included consideration of the types of solid waste streams expected, their potential for containing hazardous 


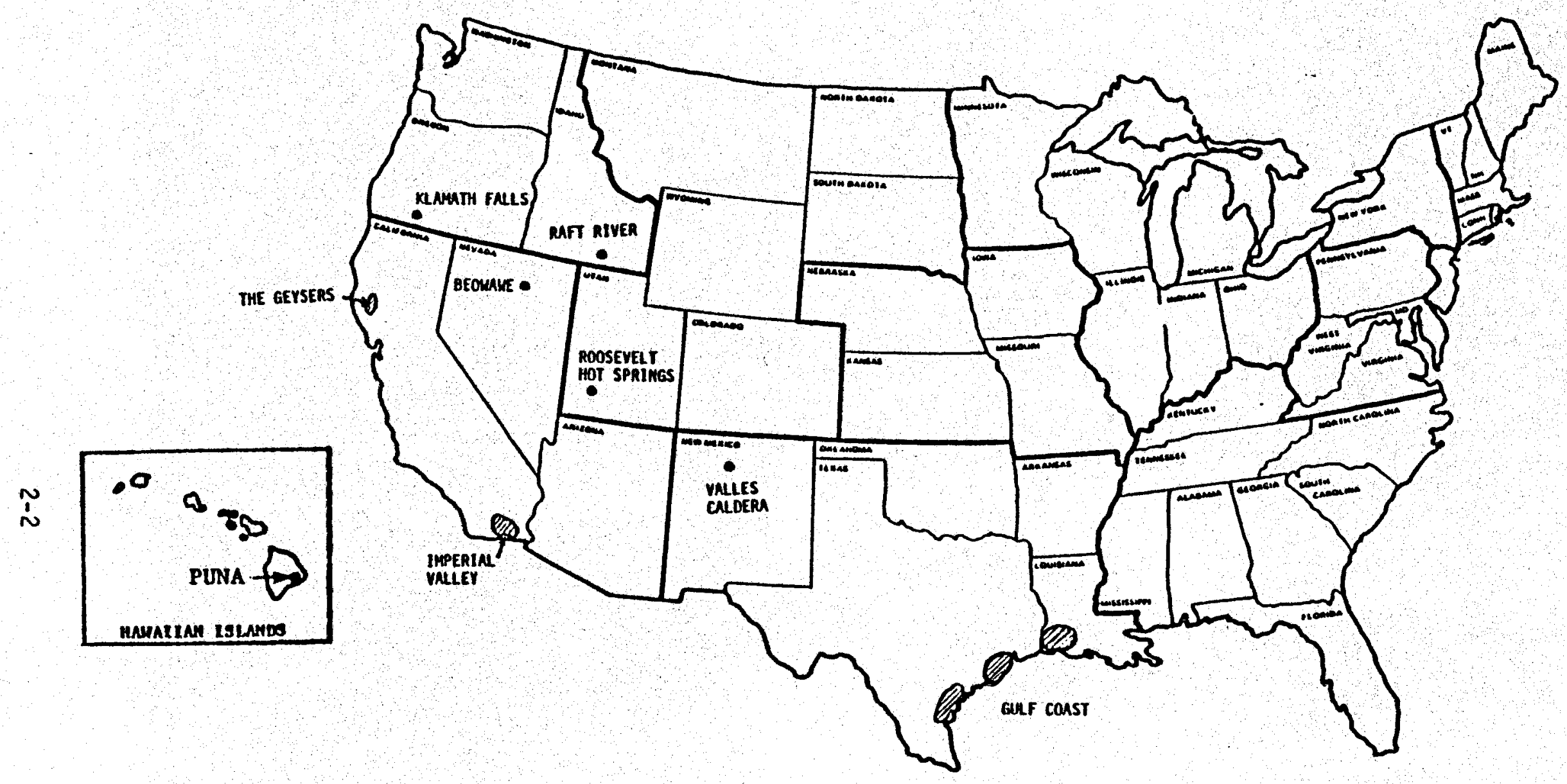

Figure 2-1. Potential Geothermal Sol id Waste Sampling Sites 
substances, and the extent to which the wastes may be indicative of comercial operations. It was al so important to obtain samples representative of a variety of geotherma] resource areas. The limit of approximately 20 samples for analys is constrained the breadth of sites considered.

Once the priority list was developed, a telephone survey of site owners/operators was begun. Over 20 individuals representing 15 organizations were contacted to determine:

- Types of solid wastes generated

- Operational status of processes producing these wastes

- Necessary procedures for obtaining permission to collect samples

As a result of the initial te lephone calls to the Group 1 and 2 sites listed here, approximately 6 to 10 suitable sampling locations each were identified in The Geysers and Imperial Valley. However, due to prolonged site inactivity, no solid wastes samples were available at either Roosevelt Hot Springs, Utah or Valles Caldera, New Mexico.

Survey efforts were then redirected to focus on the Nevada and Idaho sites. After a series of te lephone discussions with personnel responsible for the DOE Raft River project and Phillips Petroleum Company's three Nevada exploration sites, it was decided to request sampling permission for the following sites:

\section{Imperial Valley}

- DOE Geothermal Test Facility (GT), East Mesa

- Republic Geothermal wells, East Mesa and near the Niland known Geothermal Resource Area (KGRA)

- DOE Geotherma 1 Loop Experimental Facility (GLEF), Salton Sea near $\mathrm{Nil}$ and 
- Imperial County Department of Public Works Class II-2 disposal sites, Brawley and Calexico

- MAPCO we 11, Westmor land

The Geysers

- Pacific Gas \& Electric (PG\&E) power generation facilities

- Union $0 i 1$ of Callfornia wells and sedimentation pond

- Aminoil USA We $11 \mathrm{~s}$

\section{Nevada}

- Phillips Petroleum we 11s, Steamboat, Desert Peak, and Humbolt House

To facilitate obtaining site access permission and provide owners/operators with formal documentation of the purposes of the project, a letter of introduction and request to sample was prepared. A sample of this letter is presented in Appendix $A$.

A favorable response to our letter was received from each of the owners/operators contacted. In several cases, presampling site visits were conducted to discuss project objectives and sampling plans in more detai1. As a result of the telephone survey, letter transmittals, and presampling meetings, final approval was obtained to collect samples at the locations identified in Table $2-1$.

\subsection{GENERAL SAMPLING METHODS}

General methods used in the field sampling program are discussed below. Specific techniques applied to each sample collected are identified in the Sampling Field Trip Reports presented in Appendix $B$. 
Table 2-1. Approved Sites for Collecting Samples

\begin{tabular}{|c|c|c|c|c|}
\hline $\begin{array}{l}\text { Geothermal } \\
\text { Resource } \\
\text { Area }\end{array}$ & Owner/Operator & Sampling Site & Sampling Po int & $\begin{array}{c}\text { Antrefpated } \\
\text { Number of } \\
\text { Samples }\end{array}$ \\
\hline The Geysers & $\begin{array}{l}\text { PGEE } \\
\text { Amino il USA } \\
\text { Un ion ofl of } \\
\text { California } \\
\text { Cal ifornia oivi- } \\
\text { s ion of Mines and } \\
\text { Geology }\end{array}$ & $\begin{array}{l}\text { Units } 3,4,5,6 \\
\text { Unit } 11 \\
\text { Unit } 12 \\
\text { Units } 7,8 \text { or } 9,10 \\
\text { Unit } 15 \\
\text { Unit } 13 \text { or } 15 \\
\text { Orill ing operat ions } \\
\text { near Unit } 13 \\
\text { Or ill ing operat fons } \\
\text { near Unit } 14 \\
\text { Adjacent to Un it } 12 \\
\text { Orilling operat ions } \\
\text { near Un it } 18 \\
\text { (planned) } \\
\text { Cal is toga }\end{array}$ & $\begin{array}{l}\text { Centrifuge } \\
\text { Centrifuge } \\
\text { Centrifuge } \\
\text { Cooling tower bas in } \\
\text { Cooling tower bas in } \\
\text { Stretf ord process } \\
\text { Aminoll ol well } \\
\text { Aminoil } 12 \text { well } \\
\text { Abated well } \\
\text { Sedimentat ion pond } \\
\text { Unabated well } \\
\\
\text { Surf ace expression } \\
\text { Ditch deposits }\end{array}$ & $\begin{array}{l}1 \\
1 \\
1 \\
1 \\
1 \\
1 \\
1 \\
1 \\
?\end{array}$ \\
\hline $\begin{array}{l}\text { Imper lal } \\
\text { Valley }\end{array}$ & $\begin{array}{l}\text { of/Magma fower } \\
\text { DoE/Nes tee Services } \\
\text { Republic Geothermal } \\
\text { MApco/Republ te } \\
\text { Geotherma } \\
\text { Imper lal County } \\
\text { Dept. of Public } \\
\text { Works }\end{array}$ & $\begin{array}{l}\text { GLEF near N } 11 \text { and } \\
\text { GTF at East Mesa } \\
\text { East Mesa } \\
\text { Outs ide of N } 11 \text { and } \\
\text { KGRA } \\
\text { Westmor land } \\
\text { Brawley } \\
\text { Calex ieo }\end{array}$ & $\begin{array}{l}\text { Fllter press } \\
\text { Flash tank } \\
\text { Evaporation pond } \\
\text { Sperry well mo pit } \\
\text { Sperry well fluid } \\
\text { oft } \\
\text { Fee } \| \text { well mud pit } \\
\text { Fee } \| \text { well fluid } \\
\text { oit } \\
\text { Courter } \| \text { well } \\
\text { Class } I 1-2 \text { landf } i 11 \\
\text { Class } I I-2 \text { landfill }\end{array}$ & $\begin{array}{l}1 \\
1 \\
1 \\
1 \\
1 \\
1 \\
1 \\
1-2 \\
1 \\
1\end{array}$ \\
\hline Nevada & $\begin{array}{l}\text { Ph } 711 \text { ips } \\
\text { Petroleum }\end{array}$ & $\begin{array}{l}\text { Steamboat } \\
\text { Desert Peak } \\
\text { Humbolt }\end{array}$ & $\begin{array}{l}\text { Well sump } \\
\text { Well sump } \\
\text { Well sump }\end{array}$ & 1 \\
\hline
\end{tabular}




\subsubsection{Sampling Protocols}

The Acurex field sampling plan was adapted from the following two sources:

- "Field and Laboratory Sampling and Analysis Manual for the Presurvey of Solid Waste Management Practices in the Mining 1 Industry," draft report prepared by PEDCo Environmental, Inc., Cincinnati, Ohio

- "Samplers and Sampling Procedures for Hazardous Waste Streams," prepared by E. R. deVera, et al., California Department of Health Services, Berkeley, California, for the EPA/MERL-Ci, EPA-600/2-80-018, January 1980.

\section{Preliminary Considerations}

In general, sampling of solid wastes requires collecting an adequate quantity of a representative sample and maintaining its integrity through the analytical procedure.

The following steps are essential in a successful sampling program:

- Obtain permission to conduct sampling

- Research background information about the waste

- Determine sampling point

- Select proper container

- Design a sampling plan

- Observe proper sampling and handling precautions

- Deliver samples to the laboratory

- Log in samples and set up traveller for tracking Sampling Procedure for Dry Sumps

The surface area was divided into an imaginary grid and equal volumes of at least four subsamples (one from each corner) were obtained 
to provide a composite sample representative of the entire sump.

Subsamples were collected from 3 to 6 inches below the surface of the sump using a hand trowel.

Sampling Procedure for Ponds and Wet Sumps

For collecting sediment, the surface area was divided into an imaginary grid and equal volumes of at least four subsamples (one from each corner) were obtained to provide a representative composite sample. For collecting liquids, a single sample was obtained. Both types of samples were collected using a pond sampler.

\section{Miscellaneous Procedures}

Sludge from centrifuges was collected directly in the sample bottle. Samples in vats or tanks were collected by dipping. Pipe scale was removed with a hamer and chisel.

\subsubsection{Field Equipment}

All sampling equipment and containers were transported to and from the sites from Acurex's Mountain View, California offices. These included:

- Sample Containers - All samples were stored in half-gallon widemouth polyethylene bottles (Nalgene)

- Sampling Equipment -- Most samples were collected using one of two basic techniques:

- Pond Sampler - A 1-liter polyethylene beaker at the end of an 8-foot extension rod

- Hand Trowel -- Ordinary metal trowel

- Additional Field Equipment:

-. Gloves

-- Waders

-- Flashlight 
-. Maps

- Notebook

- Labels

- Rock hammer

- - Tape measure

- Compass

- Funnel

-. Safety equipment as required (i.e., goggles, hard hat, etc.)

- Camera

\subsubsection{Sample Preservation}

As this study was designed to screen geothermal wastes, elaborate preservation procedures were not attempted. Samples were collected in the field and quickly returned to the Acurex Environmental Analytical Laboratory for storage at a constant temperature of $4^{\circ} \mathrm{C}$.

\subsection{IDENTIFICATION OF SAMPLES COLLECTED}

The geothermal sampling program consisted of three field trips:

$\begin{array}{lll}\text { Resource Area } & \text { Sampling Dates } & \text { No. of Samples Collected } \\ \begin{array}{lll}\text { Imperial Valley } & \text { May } 20-23,1980 & 16 \\ \text { The Geysers } & \text { June } 3-5,1980 & 13 \\ \text { Nevada } & \text { July } 1-2,1980 & \frac{4}{33}\end{array}\end{array}$

Trip reports for each field trip are presented in Appendix B.

Tabulation of the types of solid wastes collected is given as

follows; a synopsis of the field sampling program appears in Table 2-2.

\section{Drilling sumps}

Mud/fluid 8

Mud only 3

Fluid only 5 
Table 2-2. Results of Genthermal Field Sampling Program

\begin{tabular}{|c|c|c|c|c|c|c|}
\hline $\begin{array}{l}\text { Resource } \\
\text { Area }\end{array}$ & Owner/0peratar. & Sampling Site & Sampling Point & $\begin{array}{l}\text { No. of } \\
\text { Samples } \\
\text { Collected }\end{array}$ & $\begin{array}{l}\text { Date } \\
\text { Collected }\end{array}$ & Comments \\
\hline \multirow[t]{6}{*}{$\begin{array}{l}\text { Imper lal } \\
\text { Valley }\end{array}$} & DOE/Hes tec & GTf at East Mesa & $\begin{array}{l}\text { F lash tank } \\
\text { Evaporat ion pond } \\
\text { P ipe scale }\end{array}$ & $\begin{array}{l}1 \\
2 \\
2\end{array}$ & $\begin{array}{l}5 / 20 / 80 \\
5 / 20 / 80 \\
5 / 20 / 80\end{array}$ & $\begin{array}{l}\text { Sample of wet scale from bottom } \\
\text { of tank. } \\
\text { Sampled near inlet and along } \\
\text { per imeter. } \\
\text { Inter lor of pond inlet pipe and } \\
\text { underground transfer pipe. }\end{array}$ \\
\hline & $\begin{array}{l}\text { Republic } \\
\text { Geotherma } 1\end{array}$ & $\begin{array}{l}\text { Sperry well at } \\
\text { East Mesa }\end{array}$ & $\begin{array}{l}\text { Mud pit } \\
\text { Fluid pit }\end{array}$ & 1 & $\begin{array}{l}5 / 20 / 80 \\
5 / 20 / 80\end{array}$ & Fluid low in suspended sol ids. \\
\hline & & $\begin{array}{l}\text { Fee } 1 \text { well } \\
\text { near } \mathrm{NI} \text { and KGRA }\end{array}$ & $\begin{array}{l}\text { Mud pit } \\
\text { Fluid pit }\end{array}$ & 2 & $\begin{array}{l}5 / 21 / 80 \\
5 / 21 / 80\end{array}$ & $\begin{array}{l}\text { Two interconnected pits with } \\
\text { fluid levels below connect fon } \\
\text { point. Both samples left with } \\
\text { Repubi ic (proprietary data } \\
\text { concern). }\end{array}$ \\
\hline & DOE/Magna & GLEF near Miland & Filter Press & 1 & $5 / 21 / 80$ & $\begin{array}{l}\text { Sample previously collected lon } \\
8 / 19 / 79) \text {. Reactor clarif ier no } \\
\text { longer in operation. }\end{array}$ \\
\hline & $\begin{array}{l}\text { Imper ial Co. } \\
\text { Dept. of Public } \\
\text { Morks }\end{array}$ & $\begin{array}{l}\text { N. of Brawley } \\
\text { Calexico }\end{array}$ & $\begin{array}{l}\text { Class } 11-2 \\
\text { landf } 111 \\
\text { Class } 11-2 \\
\text { landf ili }\end{array}$ & 1 & $\begin{array}{l}5 / 22 / 80 \\
5 / 22 / 80\end{array}$ & Site last used about 2 years ago. \\
\hline & MAPCO & $\begin{array}{l}\text { Cour ter In well at } \\
\text { Wes tmorland }\end{array}$ & $\begin{array}{l}\text { Mud pit } \\
\text { Baker tanks }\end{array}$ & 2 & $\begin{array}{l}5 / 23 / 80 \\
5 / 23 / 80\end{array}$ & $\begin{array}{l}\text { Flow test was in progress. Hot } \\
\text { brine collected. Analys is begun } \\
\text { on sample from one tank. Con- } \\
\text { tents of tanks should be the same. }\end{array}$ \\
\hline
\end{tabular}


Table 2-2. Concluded

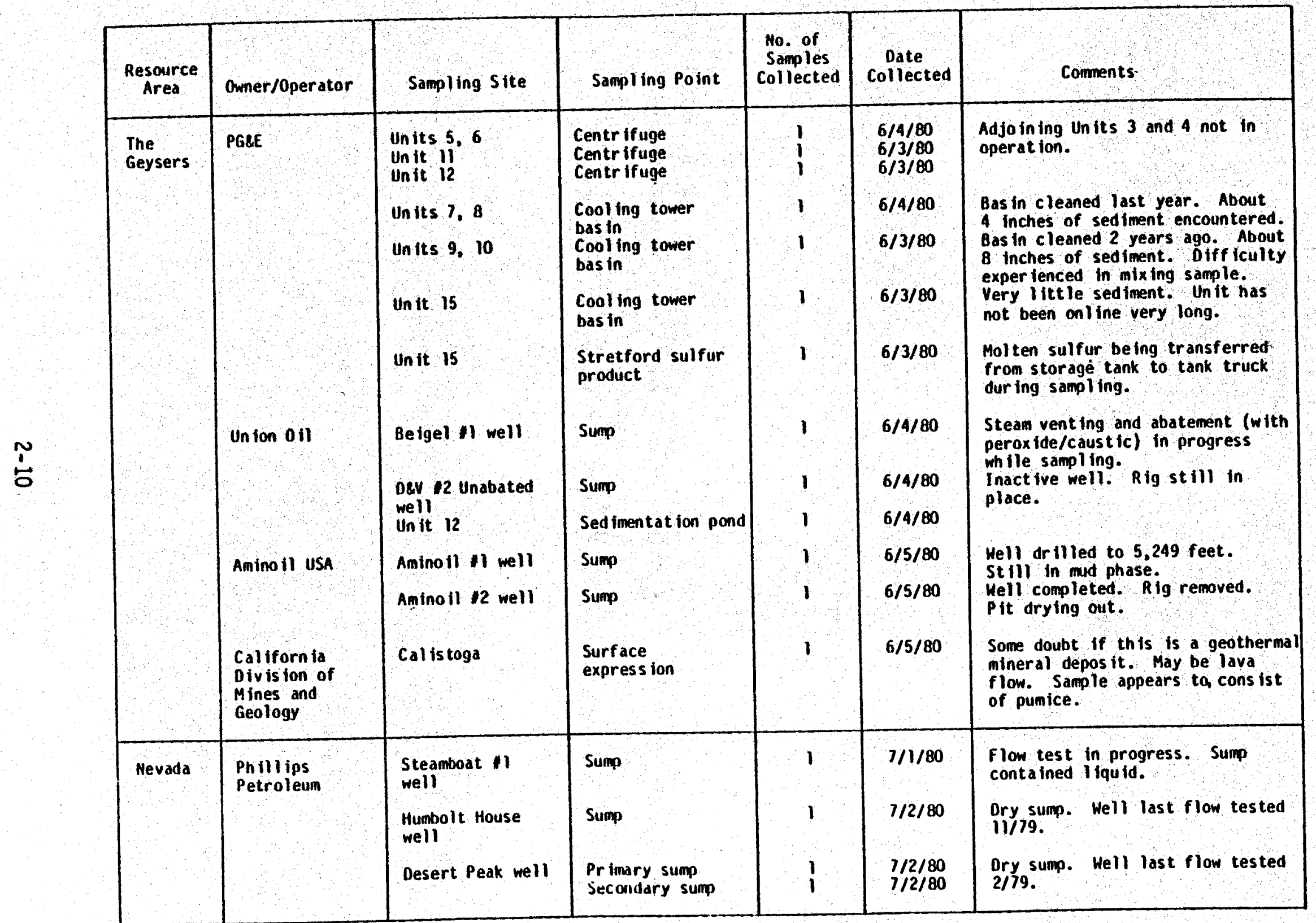


Preinjection treatment

Sediment ponds

Flash tank

Filter press

Cooling tower basins

$\mathrm{H}_{2} \mathrm{~S}$ removal

Centrifuge (iron sulfide 3

sludge dewatering)

Stretford process

sulfur recovery stream

Miscellaneous

Pipe scale

Geological surface

expression

\section{Landfills}

\subsection{METHOD DEVELOPMENT NEEDS}

Problems were encountered in sampling related to obtaining a representative sample. In some cases the samples were already homogeneous and a simple grab sample was sufficient. However, for most locations grab samples were camposited onsite and then thoroughly mixed in the laboratory. Water or unstable muds prevented sampling at the middle of many ponds and sumps. In these cases, grab samples were collected at the four corners near the edge. Sampling cooling tower sediment presented special problems. Stratification was particularly obvious since layers of many colors were present. Efforts were made to mix these in the field before sample splitting, but thorough mixing in the laboratory would have teen preferred. Most of the samples taken from sumps or ponds were 
collected at a maximum depth of about 6 inches. A good representative sample would have required a coring device mounted on a boat or suspended from a crane. This would have permitted sampling the full depth of the pond or sump, which in some cases was 8 feet or more.

When collecting a sediment sample in contact with water, the field crew must make a decision as to how much water to decant. Attempts were made to obtain a sample with a water content that would be representative of the waste as eventually disposed. However, standard procedures for sampling water-covered sediment should be developed. 


\section{SECTION 3}

\section{SAMPLE ANALYSIS}

This section discusses the analytical scheme and how it was formulated, criteria for choosing certain samples for analys is, results of the various analyses performed, quality control procedures, and method development needs.

\subsection{GENERAL ANALYTICAL APPROACH}

The focus of the analytical program was to perform those hazardous was te identification tests proposed by EPA under RCRA that were potentially applicable to geothermal solid wastes. In addition, the chemical composition of the samples was to be determined by analyzing for the major cations and anions.

\section{1 .1 Background}

EPA's proposed regulations for identifying hazardous was tes were issued on December 18, 1978 (cf 40 CFR 250, Federal Register, 43:243). Eight candidate character istics of hazardous was te were introduced, of which four: ignitability, corrosivity, reactivity, and toxicity (via an extraction procedure) were felt by the Agency to have reliable test protocols already in place. An Advance Notice of Proposed Rulemaking was published along with the proposed regulations that sought to eventually include tests for radioactivity, unnatural genetic activity, and toxicity via chronic exposure to organic chenicals. 
Consideration of the potential applicability of these characteristics to geothermal solid wastes led to a decision to test for the following:

RCRA Hazardous Was te Characteristic

Corrosivity

Toxicity (EP)

Radioactivity

Bioaccumulation Potential*
Proposed Regulations Citation

(Federal Register, 12/18/78)

40CFR $250.13(\mathrm{~b})$ 40CFR 250.13(d) 40CFR250.15(a) (5), Appendix VIII 40CFR250.15(a)(6)(ii), Appendix XI

*Only for those solid wastes for which organic additives were known or suspected to have been introduced

The extraction procedure in the toxicity test protocol was designed to simulate the leaching action of rain and groundwater in the acidic environment present in landf ills or open dumps. It calls for the sol id was te sample to be continuously exposed for 24 hours to an acidic solution. The extract is then analyzed for the presence of certain contaminants identified in the EPA National Interim Primary Or inking Water Standards (DWS). On ly the eight inorganic elements listed under 40CFR250.13(d) were included in th is study as it was not anticipated that any of the organic contaminants (all pesticides) would be found in geothermal solid wastes.

In an effort to obtain comparative data between the acidic solution EP and alternative simulations for the leaching process, an additional extraction (herein referred to as a neutral or ambient $\mathrm{pH}$ EP) was performed using delonized water as the extracting liquid in place of the specified acetic acid solution.

In addition to the OWS contaminants, eight elements not 1 is ted as part of the toxicity characteristic in the proposed regulations were included in the analytical plan. These were elements that were felt to be 
present in goothermal solid wastes and for which various western states had adopted water quality criteria.

Because of the nature of geothermal solid wastes, only those samples known to have been contacted with anthropogenic organic compounds were analyzed for bioaccumulation potential. These samples were collected from sites downstream of points of known or suspected introduction of organic additives. Organic substances are occasionally added to drilling muds to improve their physical properties, to blowdown streams to enhance coagulation of ion hydroxides, and to process streams for scale inhibition. To provide for broader indentification of organics, a screening for the acid and base/neutral priority pollutants listed in Appendix $E$ was performed in conjunction with the bioaccumulation potential test.

On May 19, 1980, EPA promulgated final regulations for portions of the RCRA hazardous waste management program proposed on December 18 , 1978. The final regulations differed from those proposed in many respects. The key changes affecting this study were:
RCRA Hazardous Waste
Characteristic
Key Changes in Final Regulations
Corrosivity
PH 1 imits changed from $\leq 3$ or $\geq 12$ to $\leq 2$ or $\geq 12.5$
Toxicity
Maximum concentrations changed from 10 to 100 times the DWS
Radioactivity
Final regulations not promulgated
Bioaccumulation potential
Final regulations not promulgated

The analytical protocols published in the December 18,1978 proposed regulations were followed throughout this study. However, these were not significantly changed in the final regulations. Corrosivity and 
toxicity analytical results are compared in Section 3.3 .4 to the May 19 , 1980 final regulations rather than to the now superceded December 18,1978 limits. As the radioactivity and bioaccumulation potential tests were not included in the final regulations, comparisons with the proposed regulations were continued.

\subsubsection{Analytical Scheme}

The analytical scheme employed for this study is shown in

Figure $3-1$. Four tests were performed on each original sample:

- Moisture content (or total suspended solids)

- Radioactivity (radium 226)

- Bulk composition (major cations and an ions)

- Corrosivity

Mo is ture content (or total suspended solids) was determined for accurate quantitation. Total sample bulk composition analyses were performed to determine the general mineral content of the material as collected. Major cations and anions analyzed for in the bulk composition analyses included:

Anjons

Chloride (Cl)

Fluoride $(F)$

Silica $\left(\mathrm{SiO}_{2}\right)$

Sulfate $\left(\mathrm{SO}_{4}\right)$

Sulfide (S)
Cations

Aluminum $(A I)$

Calcium ( $\mathrm{Ca}$ )

Iron (Fe)

Magnesium (Mg)

Potassium (K)

Sodium $(\mathrm{Na})$

Radioactivity and corrosivity are two of the characteristics of hazardous wastes. Under the final RCRA regulations, a solid waste is considered hazardous by reason of corrosivity if it exhibits a pH of less than or equal to 2 or greater than or equal to 12.5 . According to the proposed RCRA regulations, a solid waste is hazardous by virtue of 


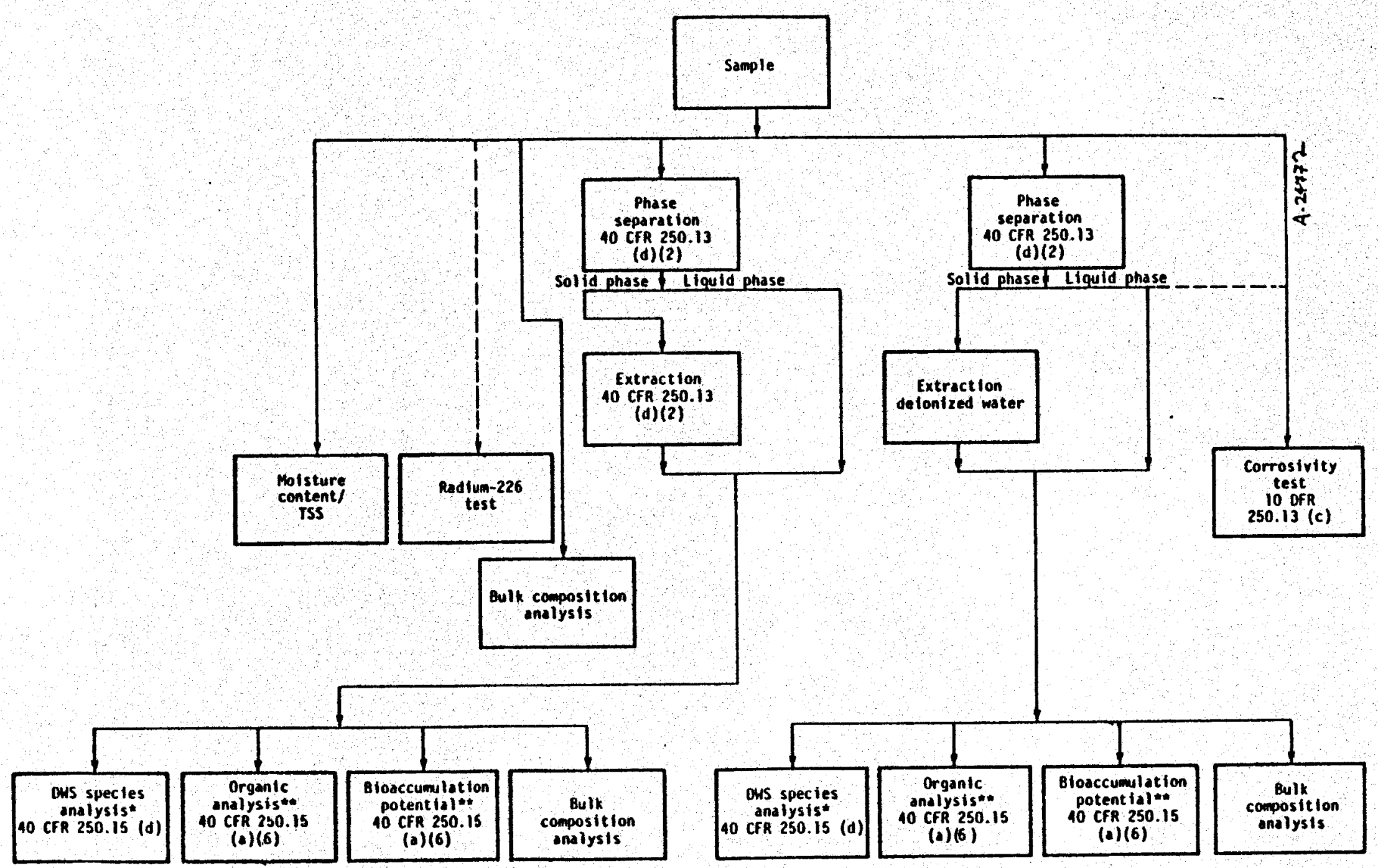

* plus additional water quality criteria trace elements

* For those samples with organic additives only

Figure 3-1. Analytical Scheme 
radioactivity if it has an average radium 226 concentration equal to or greater than 5 picocuries per gran for solids or 50 picocuries per liter for liquids.

Phase separation and extraction were performed to simulate leaching as part of the EP toxicity test. The liquid phase from phase separation and the extract (either under acid pH with acetic acid or under ambient pH with deionized water) were comb ined for further analyses. These analyses included the RCRA EP toxicity and the bioaccumulation potential tests and the bulk composition determinations on both extracts.

The eight inorganic elements in the EP toxicity test and their maximum permissable concentrations in milligrams per liter (mg/l) are:

\section{Element $\quad$ Maximum Concentration $(\mathrm{mg} / 1)^{*}$}

$\begin{array}{lr}\text { Arsenic (As) } & 5.0 \\ \text { Barium (Ba) } & 100.0 \\ \text { Cadmium ( } \mathrm{Cd}) & 1.0 \\ \text { Chromium (Cr) } & 5.0 \\ \text { Lead (Pb) } & 5.0 \\ \text { Mercury ( } \mathrm{Hg}) & 0.2 \\ \text { Selen ium (Se) } & 1.0 \\ \text { Silver (Ag) } & 5.0\end{array}$

*These values represent 100 times the OWS (cf 40CFR261.24

in Federal Register, May 19, 1980)

In addition, the following eight elements for which state water quality standards have been es tablished were included in th is study:

\begin{tabular}{|c|c|c|c|}
\hline Element & $\begin{array}{l}\text { Water Quality } \\
\text { Standard } \\
\quad(\mathrm{mg} / 1) \\
\end{array}$ & Application & State (s) \\
\hline Antimony (Sb) & No standard & -- & - \\
\hline Beryllium (Be) & 0.1 & Agricultural use & Colorado \\
\hline Boron (B) & 0.5 & All uses & Oregon \\
\hline Copper (Cu) & $\begin{array}{l}0.005 \\
0.01 \\
1.0\end{array}$ & $\begin{array}{l}\text { All uses } \\
\text { Aquatic life protection } \\
\text { Domestic water supply }\end{array}$ & $\begin{array}{l}\text { Oregon } \\
\text { Utah } \\
\text { Arizona, } \\
\text { Colorado }\end{array}$ \\
\hline
\end{tabular}




\begin{tabular}{|c|c|c|c|}
\hline Element & $\begin{array}{l}\text { Water Quality } \\
\text { Standard } \\
\text { (mg/1) }\end{array}$ & Application & State (s) \\
\hline Lithium (Li) & No standard & & \\
\hline Nickel (Ni) & $0.05-0.40 *$ & Aquatic life protection & Colorado \\
\hline Stronium $(\mathrm{Sr})$ & No standard & & \\
\hline $\operatorname{Zinc}(\mathrm{Zn})$ & $\begin{array}{l}0.01 \\
0.05 \\
5.0\end{array}$ & $\begin{array}{l}\text { All uses } \\
\text { Aquatic life protection } \\
\text { Domestic water supply }\end{array}$ & $\begin{array}{l}\text { Oregon } \\
\text { Utah } \\
\text { Arizona, } \\
\text { Colorado }\end{array}$ \\
\hline
\end{tabular}

*Standard varies as a function of stream water hardness

The bioaccumulation potential test and screening for priority pollutants were performed on the acid and ambient pH extracts for three samples known or suspected to have had organic substances added to them.

Bulk composition analyses for the major cation and anions listed above were conducted on the acid and ambient $\mathrm{pH}$ extracts for each sample. 3.1.3 Analytical Detection Limits

Detection limits for the analyses of the RCRA elements were determined by considering the RCRA maximum concentrations (cf Federal Register, May 19, 1980, p. 33122) and the National Interim Primary Drink ing Water Standards on which they were based. These are compared below:

\begin{tabular}{lccc} 
& $\begin{array}{c}\text { RCRA Maximum } \\
\text { Concentration } \\
\text { (mg/L) }\end{array}$ & $\begin{array}{c}\text { Or ink ing Water } \\
\text { Standard } \\
\text { (mg/L) }\end{array}$ & $\begin{array}{c}\text { Analytical } \\
\text { Detection Limit } \\
\text { (mg/L) }\end{array}$ \\
\cline { 2 - 2 } & 5.0 & 0.05 & $\frac{0.02}{2}$ \\
Arsarium & 100.0 & 1.0 & 0.3 \\
Cadmium & 1.0 & 0.01 & 0.005 \\
Chromium & 5.0 & 0.05 & 0.02 \\
Lead & 5.0 & 0.05 & 0.02 \\
Mercury & 0.2 & 0.002 & 0.001 \\
Selenium & 1.0 & 0.01 & 0.02 \\
Silver & 5.0 & 0.05 & 0.02 \\
& & &
\end{tabular}


The detection limits chosen are significantly below the RCRA limits. For a11 metals except selenium, the detection limit is less than 0.5 percent of the RCRA level. For selenium, the detection 1 imit is 2 percent of the RCRA level.

\section{2, SELECTION OF SAMPLES FOR ANALYSIS}

While the field sampling program yielded 33 samples, the project scope permitted only about 20 samples to be analyzed. Accordingly, a priority listing of all the samples collected was developed to facilitate the selection process. Factors considered in $r$ ank ing the samples included the following:

- Sample quality _ - samples taken from was te streams containing little material or from long, inactive sumps or landf ills were given low rankings

- Geothermal resource variability -- a mix of samples representing the various geographic areas in the Imperial Valley and at The Geysers was desired

- Commercial operations applicability - samples of solid wastes most closely associated with those expected of commercial operations were given high rank ings

The priority listing of the samples is presented in Table $3-1$. As more than one sample was collected at several of the sampling points, this 1 ist includes 28 and 33 samples obtained during the three field trips.

Final selection of the samples was based on a maximum for analys is of 20 (plus a duplicate of one sample); all 20 would be tested for radium 226 and 3 of the samples would be analyzed for organics (priority pollutants and bioaccumulation potential). The 20 selected samples are identified in Table $3-2$. 
Table 3-1. Priority Listing of Samples for Analysis

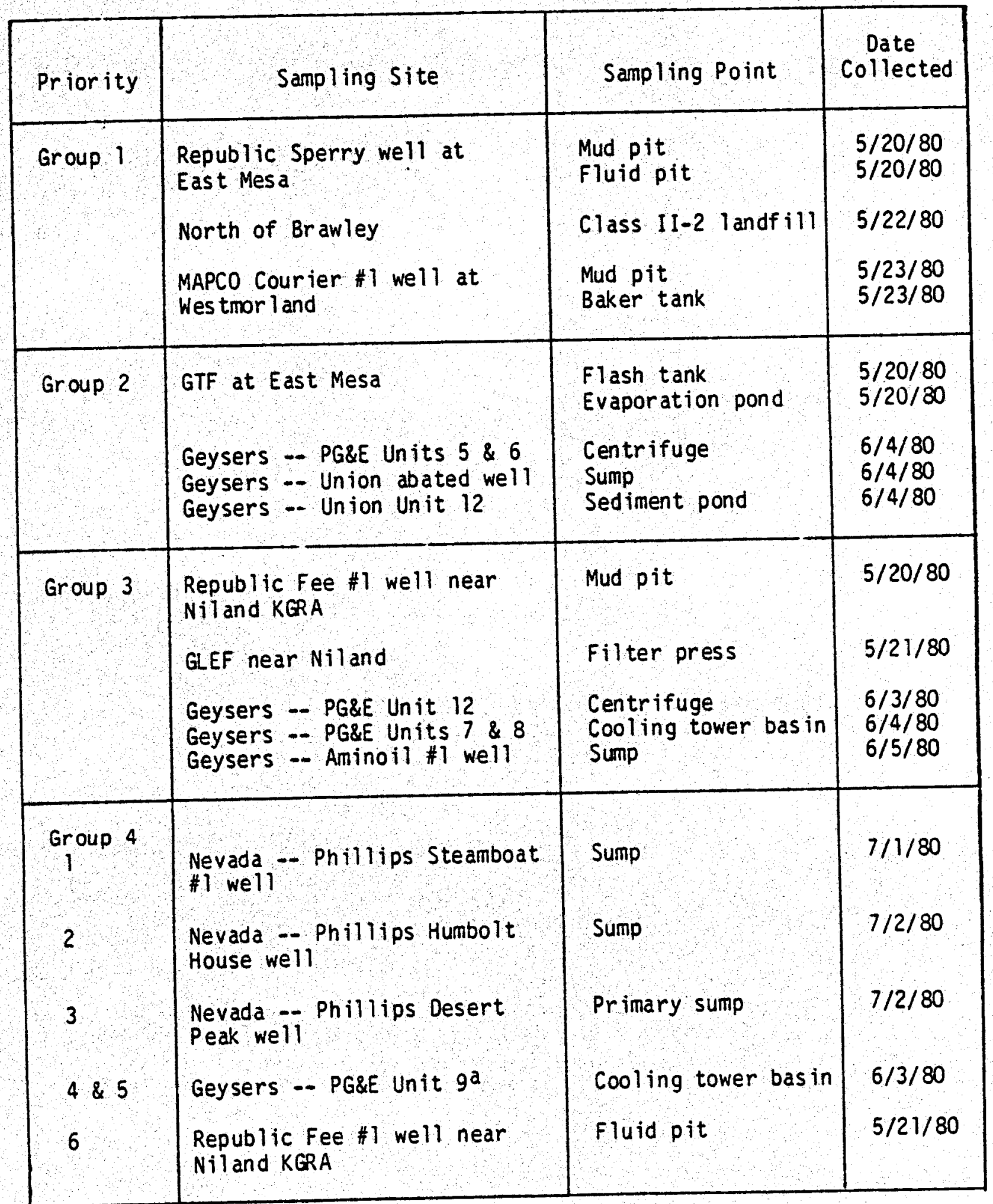

aTo be analyzed in duplicate 
Table 3-1. Concluded

\begin{tabular}{|c|c|c|c|}
\hline Priority & Sampling site & Sampling Point & $\begin{array}{l}\text { Date } \\
\text { Collected }\end{array}$ \\
\hline 7 & GTF at East Mesa & Bypass pipe scale & $5 / 20 / 80$ \\
\hline 8 & Geysers - Aminoil \#2 well & Sump & $6 / 5 / 80$ \\
\hline 9 & Geysers - Union unabated well & Sump & $6 / 4 / 80$ \\
\hline 10 & GTF at East Mesa & $\begin{array}{l}\text { Pond inlet } \\
\text { pipe scale }\end{array}$ & $5 / 20 / 80$ \\
\hline 11 & Geysers - PG\&E Unit 15 & $\begin{array}{l}\text { Stretford } \\
\text { sulfur product }\end{array}$ & $6 / 3 / 80$ \\
\hline 12 & Geysers - PG\&E Unit 11 & Centrifuge & $6 / 3 / 80$ \\
\hline 13 & Calistoga & Surface expression & $6 / 5 / 80$ \\
\hline
\end{tabular}


Table 3-2. Final Selection of Samples for Analys is

\begin{tabular}{|c|c|c|c|c|c|c|}
\hline Priorley, & Sanpling site & Sampling Point & $\begin{array}{l}\text { Date } \\
\text { Collected }\end{array}$ & $\begin{array}{c}\text { Date Analys is } \\
\text { Begun }\end{array}$ & Radium 226 & Organtes \\
\hline Grasp 1 & $\begin{array}{l}\text { Repubile Sperry well at } \\
\text { East Mes } \\
\text { N. of orawley } \\
\text { MAPCo Courier of well at } \\
\text { Ues tmor land }\end{array}$ & $\begin{array}{l}\text { Mud pit } \\
\text { Fluid pit } \\
\text { Class } 11-2 \text { landf } 111 \\
\text { Mud pit } \\
\text { Baxer tank }\end{array}$ & $\begin{array}{l}5 / 20 / 80 \\
5 / 20 / 80 \\
5 / 22 / 80 \\
5 / 23 / 80 \\
5 / 23 / 80\end{array}$ & $\begin{array}{l}5 / 29 / 80 \\
5 / 29 / 80 \\
5 / 29 / 80 \\
5 / 29 / 80 \\
5 / 29 / 80\end{array}$ & $\begin{array}{l}x \\
x \\
x \\
x \\
x\end{array}$ & $x$ \\
\hline Grow 2 & $\begin{array}{l}6 T \text { at East Mesa } \\
\text { Geysers - PGse Units } 5 \\
\text { Geysers - Union abated weil } \\
\text { Geysers - Union Unit } 12\end{array}$ & $\begin{array}{l}\text { Elash tank } \\
\text { Evaporation pond } \\
\text { Centrifuge } \\
\text { Sump } \\
\text { Sediment pond }\end{array}$ & $\begin{array}{l}5 / 20 / 80 \\
5 / 20 / 80 \\
6 / 4 / 80 \\
6 / 4 / 80 \\
6 / 4 / 80\end{array}$ & $\begin{array}{l}6 / 16 / 80 \\
6 / 16 / 80 \\
6 / 16 / 80 \\
6 / 16 / 80 \\
6 / 16 / 80\end{array}$ & $\begin{array}{l}x \\
x \\
x \\
x \\
x\end{array}$ & $\begin{array}{l}x \\
x\end{array}$ \\
\hline Group 3 & $\begin{array}{l}\text { Republlic Fee } 1 \text { well near } \\
\text { Miland KGRA } \\
\text { EEF at Salton Sea } \\
\text { Geysers - PGEE Unit } 12 \\
\text { Geysers - PGAE Units } 7 \text { \& } 8 \\
\text { Geysers - Aminoil } 1 \text { well }\end{array}$ & $\begin{array}{l}\text { Mud pit } \\
\text { fllter press } \\
\text { Centrifuge } \\
\text { Cooling tower basin } \\
\text { Sump }\end{array}$ & $\begin{array}{l}5 / 20 / 80 \\
5 / 21 / 80 \\
6 / 3 / 80 \\
6 / 4 / 80 \\
6 / 5 / 80\end{array}$ & $\begin{array}{l}6 / 16 / 80 \\
6 / 16 / 80 \\
6 / 16 / 80 \\
6 / 16 / 80 \\
6 / 16 / 80\end{array}$ & $\begin{array}{l}x \\
x \\
x \\
x \\
x\end{array}$ & \\
\hline Group 4 & $\begin{array}{l}\text { Mevada }- \text { Phillips Ste umboat } \\
1 \text { well }\end{array}$ & Sump & $7 / 1 / 80$ & $7 / 8 / 80$ & $x$ & \\
\hline 2 & $\begin{array}{l}\text { Kevada - Philips Hunbolt } \\
\text { well }\end{array}$ & Sump & $7 / 2 / 80$ & $7 / 8 / 80$ & $x$ & \\
\hline 3 & $\begin{array}{l}\text { Nevada - Phlllips Desert } \\
\text { Peak well }\end{array}$ & Primary sump & $7 / 2 / 80$ & $7 / 8 / 80$ & $x$ & \\
\hline 415 & Geysers - PGEE UnIt $9^{d}$ & Cooling tower dasin & $6 / 3 / 80$ & $7 / 8 / 80$ & $x$ & \\
\hline 6 & $\begin{array}{l}\text { Republic Fee } 1 \text { well near } \\
\text { Nil and KERA }\end{array}$ & & $5 / 21 / 80$ & $7 / 8 / 80$ & $x$ & \\
\hline
\end{tabular}

aouplicates to be analyzed. No bulk compositions to be performed. 


\section{$3.3 \quad$ ANALYTICAL RESULTS}

The analytical results are presented in this section for the following analyses:

- Corros jvity

- Radioactivity

- EP toxicity

- Organics

- Bulk composition

In each of the above, the measurement technique employed is described, the results obtained are tabulated, and any specific analytical problems encountered are identified.

Detailed discussions of the analytical methods used are provided in Appendix $C$. The complete set of analytical results for each sample is included in Appendix 0.

To facilitate identifying the various samples in the results tables in this section, a key to the sample numbers and their descriptions is presented in Table $3-3$

\subsubsection{Corrosivity}

Corrosivity was determined by measuring the $\mathrm{pH}$ of a 5 weight percent slurry of the sample for solids. Liquids were measured directly. Results are given in Table $3-4$.

\subsubsection{Radioactivity}

Radium 226 analyses were performed on 20 samples as a measure of radioactivity. Results are presented in Table $3-5$ in $\mathrm{pCi} / \mathrm{g}$ for all samples except for two liquids samples which are reported in $\mathrm{PC} I / L$. Sample G10 was essentially a liquid but had high total suspended solids (TSS) and was determined on the bas is of total solids and reported as 
Table 3-3. Key to Identifying Samples

\begin{tabular}{|c|c|c|c|c|c|}
\hline \multicolumn{2}{|c|}{ Samp le Number } & \multirow[b]{2}{*}{ Sanple Description } & \multirow[b]{2}{*}{ Location } & \multirow{2}{*}{$\begin{array}{l}\text { Geothermal } \\
\text { Resource } \\
\text { Area (GRA) }\end{array}$} & \multirow[b]{2}{*}{ Site Omer/Operator } \\
\hline Field & Lab & & & & \\
\hline 61 & 1428 & Dowell Flash Tank & $\begin{array}{l}\text { Geothermal Test Facillty, } \\
\text { East Mesa }\end{array}$ & TV & DE / Westec Services \\
\hline 63 & 1430 & Brine Holding Pond & $\begin{array}{l}\text { Geothermal Test Facility, } \\
\text { East Mesa }\end{array}$ & IV & OOEMestec Services \\
\hline 66 & 1433 & Mud PIt, Sperry Well & East Mes a & Iv & Republic Geothermal \\
\hline 67 & 1434 & Fluid Pit, Sperry Hell & East Mesa & IV & Republic Geothermal \\
\hline 68 & 1435 & $\begin{array}{l}\text { Clarifier Reactor Sludge } \\
\text { Underf low }\end{array}$ & $\begin{array}{l}\text { Geothermal Loop E } \\
\text { Near Nil and }\end{array}$ & iv & DoE/Magha Power \\
\hline 69 & 1436 & Mud Pit, Fee 11 Nell & Near Niland & IV & Republic Geothermal \\
\hline 610 & 1676 & North Brine Pit, fee ol well & Near Ntliand & IV & Republic Geothermal \\
\hline 612 & 1437 & Class $11-2$ Landf 111 & Brawley & IV & $\begin{array}{l}\text { Imper ial County Dept. } \\
\text { of Public Norks }\end{array}$ \\
\hline 614 & 1439 & $\begin{array}{l}\text { East Baker Tank, } \\
\text { Courier } 11 \text { Hell }\end{array}$ & Hes tmor l and & IV & MAPCO \\
\hline 616 & 1441 & Mud Pit, Courfer if Well & Wes tnorland & iv & MAPCO \\
\hline 619-2 & 1576 & Iron sludge from centrifuge & Unit 12 & G & PGLE \\
\hline $620-1$ & $1577 \mathrm{~A}$ & Cooling Tower Sediment & Unit 9 & G. & PG\&E \\
\hline $620-1$ & 15778 & Cooling Tower sediment & Unit 9 & 6 & PG\&E \\
\hline $622-1$ & 1579 . & Iron Sludge fron Centrifuge & Units $5: 6$ & 6 & PG\&E \\
\hline $623-1$ & 1580 & Cooling Tower Sedinent & Units 788 & 6 & PGQE \\
\hline $624-1$ & $1581 R$ & $\begin{array}{l}\text { Abated Well Sump, Beigel } \\
\text { II Well }\end{array}$ & Near Unit 18 & 6 & Union otl of California \\
\hline 626-1 & $1585 R$ & Sedimentation Pond & Unit 12 & 6 & Union otl of California \\
\hline $627-1$ & 1587 & $\begin{array}{l}\text { Sunp in Mud ortlling Phase, } \\
\text { Aminoil } 11 \text { Well }\end{array}$ & Near Unit 13 & G & Aminoil USA \\
\hline 630 & 1668 & Sump, Steamboat 11 well & Ste amboat & $n$ & Phillips Petroleum \\
\hline 631 & 1669 & Sump, Hunoolt House Well & Hunbolt & $N$ & Phillios Petroleum \\
\hline 632 & 1670 & $\begin{array}{l}\text { Primary Sump, Desert Peak } \\
\text { Well }\end{array}$ & Desert Peak & $N$ & Phillips Petroleum \\
\hline
\end{tabular}

IV * Impertal valley

$G$ - The Geysers

$N$ Nevada 
Table 3-4. Corrosivity in Order of Increasing pH

\begin{tabular}{|c|c|c|c|}
\hline $\begin{array}{l}\text { Sample } \\
\text { Number }\end{array}$ & Sample Description & $\begin{array}{l}\text { Geothermal } \\
\text { Resource Area }\end{array}$ & $\mathrm{pH}$ \\
\hline 610 & North Brine Pit & IV & 1.6 \\
\hline G20 & Cooling Tower Sediment & G & 3.7 \\
\hline G14 & East Baker Tank & IV & 3.8 \\
\hline G26-1 & Sedimentation Pond & G & 4.2 \\
\hline G23-1 & Cooling Tower Sediment & G & 5.1 \\
\hline G8 & Clarifier Sludge & IV & 6.1 \\
\hline G19-1 & Iron sludge & G & 6.2 \\
\hline G22-1 & Ir on Sludge & $G$ & 6.6 \\
\hline G9 & Mud Pit & IV & 8.4 \\
\hline G7 & Fluid Pit & IV & 8.7 \\
\hline G16 & Mud Pit & IV & 8.8 \\
\hline G1 & Flash Tank Scale & IV & 8.8 \\
\hline G3 & Brine Holding Pond & IV & 8.8 \\
\hline G32 & Primary Sump & N & 9.1 \\
\hline 630 & Sump & N & 9.3 \\
\hline G27 & Sump & $G$ & 9.6 \\
\hline G31 & Sump & N & 9.8 \\
\hline G24-1 & Well Sump & $G$ & 10.0 \\
\hline$G 12$ & Class II- 2 Landf 111 & IV & 10.0 \\
\hline G6 & Mud P it & IV & 12.0 \\
\hline
\end{tabular}


Table 3-5. Radium 226 In Order of Increasing Activity

\begin{tabular}{|c|c|c|c|}
\hline $\begin{array}{l}\text { Field } \\
\text { Number }\end{array}$ & Sample Description & $\begin{array}{l}\text { Geothermal } \\
\text { Resource Area }\end{array}$ & $\mathrm{pCi} / \mathrm{g}$ \\
\hline $620-1$ & Cool ing Tower Sediment & G & 0 \\
\hline G26-1 & Sedimentation Pond & G & 0 \\
\hline G23-1 & Cooling Tower Sediment & $G$ & 0 \\
\hline G19-1 & Iron Sludge & G & 0 \\
\hline G22-1 & Iron sludge & G & 0 \\
\hline 67 & Fluid Pit & IV & 0 \\
\hline G10 & North Brine Pit & IV & 0.4 \\
\hline G27-1 & Sump & G & 0.4 \\
\hline G24-1 & Sump & G & 0.5 \\
\hline G30 & Sump & N & 1.0 \\
\hline 66 & Mud Pit & IV & 1.0 \\
\hline 612 & Class $11-2$ Landf $i 11$ & IV & 1.15 \\
\hline 63 & Brine Holding Pond & IV & 1.5 \\
\hline G31 & Sump & N & 1.6 \\
\hline G9 & Mud Pit & IV & 2.1 \\
\hline GI & Flash Tank Scale & IV & 3.0 \\
\hline G32 & Primary Sump & N & 3.8 \\
\hline G16 & Mud Pit & IV & 5.9 \\
\hline G8 & Clarifier Sludge & IV & 78 \\
\hline G14 & East Baker Tank & IV & $1320^{a}$ \\
\hline
\end{tabular}

$a_{p C i / L}$ 
pCi/g. All values in $T a b l e ~ 3-5$ except for samples $G 7$ and $G 14$ are reported on a dry basis.

\section{3 .3 EP Toxicity}

Samples were prepared for analysis by the extraction procedures described previously. The bulk sample was filtered, the residue extracted under acid and neutral (ambient). pH conditions and filtered, and the original and final filtrate combined. Three samples (G7, G10, and G14) were geothermal br ines with less than 0.5 percent TSS. These were not extracted but were filtered and the filtrate analyzed.

Analyses were performed on the acid and ambient pH extracts for a total of 16 elements: 8 RCRA regulated and 8 additional metals. Results are presented in Table 3-6 for the RCRA elements and Table 3-7 for the additional metals. All anayses except for bor on were performed by atomic absorption spectroscopy (AA). Boron was measured by the Curcumin colorimetric method.

Because of high levels of colloidal material in a number of samples, problems were encountered in filtration both before and after extraction. Table $3-8$ identifies alternate procedures used to circumvent these difficulties. In all cases except for the sample $G 12$ ambient $p H$ extract, the procedures recommended in Appendix II of the final RCRA regulations (cf Federal Register, May 19, 1980, p. 33127) were followed. Filtration after centrifugation could not be successfully performed on the sample G12 amb ient pH extract.

offficulties encountered in analyzing the extracts included the following:

- Interferences prevented quantitation of mercury in two samples: $G 12$ (ambient $\mathrm{pH}$ extract) and G10 
Table 3-6. RCRA Trace Elements in Order of Decreasing Total Trace Elements ( $\mathrm{mg} / \mathrm{l})$ in Acid Extract

\begin{tabular}{|c|c|c|c|c|c|c|c|c|c|c|c|c|c|c|c|c|c|c|c|c|}
\hline \multirow[b]{2}{*}{$\begin{array}{l}\text { Somple } \\
\text { Humber }\end{array}$} & \multirow[b]{2}{*}{$\begin{array}{l}\text { Sample } \\
\text { Type }\end{array}$} & \multirow[b]{2}{*}{$\operatorname{GA}$} & \multicolumn{2}{|c|}{ Arsentc } & \multicolumn{2}{|c|}{ Barium } & \multicolumn{2}{|c|}{ Codmiun } & \multicolumn{2}{|c|}{ Chromium } & \multicolumn{2}{|c|}{ lead } & \multicolumn{2}{|c|}{ Mercury } & \multicolumn{2}{|c|}{ Selen lum } & \multicolumn{2}{|c|}{ silver. } & \multicolumn{2}{|c|}{ Total } \\
\hline & & & NEP: & KEP & AEP & NEP & NEP & NEP & NEP & NEP & AEP & MEP & AEP & MEP & NEP & MEP & AEP & NEP & EEP & MeP \\
\hline 610 & Brine & iv & -- & $n$ & - & 363 & - & 0.07 & - & 0.98 & - & $M R$ & - & IHT & - & $\mathbf{m}$ & - & ma & -- & 364 \\
\hline 614 & Orine & IV & - & 14 & - & 22 & - & 4 & - & $m$ & - & 63 & -- & $n$ & - & 5.1 & - & $n$ & - & 128 \\
\hline 616 & Mid & IV & 0.049 & 0.047 & 13 & 6.8 & 0.020 & in & no & $\mathrm{mo}$ & 0.060 & mo & $\mathrm{MO}$ & $n$ & 0.10 & 0.12 & ND & m & 13.2 & 6.9 \\
\hline 61 & Scale & IV & 0.036 & 0.033 & 10.5 & $n$ & 10 & $m$ & mo & $m$ & mo & $\mathrm{mo}$ & No & nD & no & no & ND & no & 10.5 & 0.03 \\
\hline 68 & Sludge & IV & 0.23 & 0.23 & 5.0 & 5.4 & $m$ & $m$ & $\mathrm{~m}$ & no & 0.20 & mo & $\mathrm{mo}$ & no & 0.18 & 0.22 & No & mo & 5.61 & 5.85 \\
\hline 63 & Sediment & IV & 0.045 & 0.065 & 3.8 & 0.60 & mo & mo & $m$ & m & mo & No & mo & m & mo & $m$ & No & $m$ & 3.85 & 0.67 \\
\hline 69 & Mud & IV & 0.063 & 10 & 1.8 & no & 0.006 & mo & mo & mo & $m$ & $m$ & mo & $m$ & 0.030 & 0.020 & no & no & 1.90 & no \\
\hline $627-1$ & Mud & 6 & no & 0.032 & 1.4 & 10 & mo & No & 0.070 & mo & wo & No & $m$ & no & mo & $m$ & No & no & 1.91 & 0.03 \\
\hline 66 & nid & IV & $m$ & $m$ & 1.4 & no & $n$ & $m$ & 0.030 & $m$ & no & $m$ & $n$ & 10 & no & $m$ & mo & $m$ & 1.43 & mo \\
\hline 631 & Hid & $n$ & $m$ & 0.014 & 0.60 & 0.50 & 0.006 & 0.005 & mo & 0.027 & 0.70 & 0.50 & mo & no & no & no & no & no & 1.30 & 0.17 \\
\hline 612 & Mixed Sol & IV & 0.10 & $m$ & 1.0 & 1.4 & $m$ & $m$ & 0.023 & 0.12 & Mo & 0.20 & No & INT & no & MA & mo & mo & 1.12 & 2.02 \\
\hline 630 & Mud & $n$ & 0.06 & 0.26 & 0.60 & no & mo & Na & $M$ & wo & no & No & $m$ & NO & wo & mo & NO & 10 & 0.66 & 0.26 \\
\hline 632 & Mud & $n$ & $m$ & 0 & 0.50 & $m$ & $m$ & $m$ & 10 & 0.039 & $m$ & $\mathbf{m}$ & $m$ & mo & 0.030 & na & $n$ & 10 & 0.53 & 0.39 \\
\hline 67 & Orine & IV & - & 0.31 & - & No & - & $m$ & - & MO & - & no & - & mo & - & no & - & No & - & 0.31 \\
\hline $620-18$ & Sediment & 6 & 0.081 & 0.068 & $n$ & in & 0.010 & 0.010 & 0.029 & 0.023 & 0.140 & 0.180 & MD & No & mo: & m & mo & $m$ & 0.27 & 0.28 \\
\hline $620-1 A^{*}$ & Sediment & 6 & 0.088 & 0.051 & mo & mo & 0.013 & 0.014 & 0.051 & 0.020 & 0.100 & 0.130 & no & no & $m$ & mo & $m$ & mo & 0.25 & 0.22 \\
\hline $623-1$ & Sedinent & 6 & 0.110 & 0.150 & $m$ & $n$ & $M$ & $m$ & mo & m & 0.070 & 0.050 & No & no & $m$ & no & mo & mo & 0.18 & 0.20 \\
\hline $626-1$ & Sediment & 6 & 0.020 & 0.034 & $n$ & (n) & 0.008 & 0.000 & 0.053 & mo & no & no & mo & no & 0.030 & 0.040 & No & mo & 0.11 & 0.08 \\
\hline $622-1$ & Sludge & 6 & in & 0 & $n$ & no & to & $n$ & mo & no & 0.020 & 0.050 & No & mo & 10 & no & mo & no & 0.02 & 0.05 \\
\hline 619-1 & Sludge & 6 & no & $n$ & $m$ & $m$ & no & $m$ & $m$ & mo & mo & MB & no & no & no & 10 & No & ND & no & no \\
\hline $624-1$ & Mud & 6 & no & 90 & No & 10 & 10 & ma & no & mo & MO & no & no & mo & mo & mo & mo & no & no & mo \\
\hline
\end{tabular}

\footnotetext{
AEP Acid extraction procedure N N Mevada

In In Interference $\quad-\quad$ Not applicable

6 The Geysers

Amb ient pH (neutral)

Mot reported

- Not detected
} 
Table 3-7. Additional Metals in Order of Decreasing Total Trace Elements (mg/l) in Acid Extract

\begin{tabular}{|c|c|c|c|c|c|c|c|c|c|c|c|c|c|c|c|c|c|c|c|c|}
\hline \multirow[b]{2}{*}{$\begin{array}{l}\text { Sumple } \\
\text { Mubber }\end{array}$} & \multirow[b]{2}{*}{$\begin{array}{l}\text { Simple } \\
\text { Type }\end{array}$} & \multirow[b]{2}{*}{$\operatorname{cas}$} & \multicolumn{2}{|c|}{ Antimony } & \multicolumn{2}{|c|}{ Derylltum } & \multicolumn{2}{|c|}{ Boran } & \multicolumn{2}{|c|}{ Copper } & \multicolumn{2}{|c|}{ Ithlum } & \multicolumn{2}{|c|}{ Mickel } & \multicolumn{2}{|c|}{ Strontlum } & \multicolumn{2}{|c|}{ Zinc } & \multicolumn{2}{|c|}{ Total } \\
\hline & & & AEP & MEP & AEP & MEP & AEP & MEP & AEP & MEP & AEP & NEP & AEP & MEP & AEP & NEP & AEP & MEP & AEP & NEP \\
\hline 614 & Brine & IV & -- & $m$ & - & $\mathrm{mo}$ & - & 230 & - & mo & $\cdots$ & 0.24 & $-\infty$ & mo & $\cdots$ & 1400 & - & 6000 & -- & 7630 \\
\hline 610 & Brine & IV & - & 10 & - & $M$ & - & 660 & - & 7.10 & - & m & - & 0.30 & - & 1290 & - & $M$ & - & 1960 \\
\hline $623-1$ & Sediment & 6 & no & $M$ & 10 & No & 1.70 & 0.88 & 60 & 33 & $\mathbf{m}$ & 10 & $m$ & no & $n$ & in & 7.5 & 6.0 & 67.7 & 39.9 \\
\hline 68 & Sludge & Iy & mo & $m$ & mo & $m$ & 12.0 & 13.0 & 0.15 & no & 5.8 & Mo & 0.50 & No & 12.0 & 15.0 & 6,4 & 4.0 & 37.8 & 39.9 \\
\hline 616 & mud & IV & n & $n$ & no & no & 0.25 & 3.10 & $m$ & 10 & 3.3 & 3.1 & no & No & 23.0 & 20.0 & 17.0 & no & 33.3 & 24.4 \\
\hline $620-11$ & Sediment & 6 & 10 & no & no & $m$ & 23.0 & 16.0 & 2.2 & 1.8 & $m$ & $\mathrm{~m}$ & 0.90 & 0.70 & mo. & no & 6.20 & 6.00 & 32.3 & 24.5 \\
\hline $626-1$ & Sediment & $G$ & No & no & $n$ & 10 & 19.0 & 30.0 & $m$ & $m$ & $\mathrm{~m}$ & $m$ & 0.40 & 0.40 & mo & mo & 9.0 & 14.0 & 28.4 & 34.4 \\
\hline $622-1$ & Sludge & 6 & no & $m$ & no & no & 20.0 & 27.0 & mo & mo & ma & 0.10 & 0.20 & $m$ & $\mathbf{m}$ & $m$ & 0.06 & 0.03 & 28.2 & 27.1 \\
\hline $620-18$ & Sediment & 6 & no & $M$ & 10 & No & 13.0 & 13.0 & 1.9 & 1.1 & No & $n$ & 0.7 & 0.6 & Wo & no & 5.0 & 4.5 & 20.6 & 19.2 \\
\hline & Sediment & IV & mo & $m$ & mo & no & mo & mo & $\mathbf{M}$ & No & 0.17 & 0.13 & m & mo & B.3 & mo & 0.110 & $m$ & 8.60 & 0.13 \\
\hline $619-1$ & Sludge & 6 & m & $M$ & D & 10 & 7.6 & 0.52 & mo & m & $\mathrm{MB}$ & $m$ & mo & No & mo & no & 0.20 & 0.05 & 0.10 & 0.57 \\
\hline 69 & mus & IV & No & no & no & mo & mo & 0.20 & $m$ & $M$ & 1.30 & 1.10 & mo & m & 5,1 & 1.5 & 1.3 & mo & 8.0 & 2.8 \\
\hline 627 & mad & 6 & 10 & 10 & no & 10 & no & mo & No & $M$ & mo & $m$ & no & m & 3.5 & No & 0.08 & No & 3.6 & HD \\
\hline 631 & Mud & n & no & no & mi & m & $m$ & $\mathbf{m}$ & $m$ & 0.10 & 0.05 & $m$ & no & ND & 3.0 & mo & 0.42 & 0.28 & 3.5 & 0.34 \\
\hline 632 & Mud & $n$ & no & no & $n$ & m & 0.23 & 0.17 & 0.20 & 0.10 & 0.30 & 0.20 & NO & $\mathrm{No}$ & 2.6 & $\mathrm{ma}$ & 0.14 & 0.05 & 3.5 & 0.82 \\
\hline G) & Brine & IV & - & mo & $\cdots$ & no & - & no & - & mo & - & 2.8 & - & mo & - & No & - & 0.03 & - & 2.8 \\
\hline 612 & Mixed sol & IV & no. & n & 10 & n & No & 0.34 & mo & 0.23 & 0.13 & 0.34 & HO & no & 2.4 & in & 0.25 & 1.4 & 2.8 & 2,0 \\
\hline & mid & iv & mo & mis & mo & mo & 10 & $\infty$ & no & $M$ & $m$ & mo & no & ND & 2.2 & $M$ & 0.15 & $n$ & 2.4 & no \\
\hline G24-1 & mod & 6 & $m$ & $n$ & no & mo & 0.87 & 15.0 & No & mo & $m$ & mo & 0.30 & 0.50 & 0.60 & AB & 0.30 & no & 2.1 & 15.5 \\
\hline 630 & Mud & $n$ & 10 & 0.07 & $\mathrm{~m}$ & $m$ & 0.30 & 0.57 & Mo & $m$ & 0.50 & 0.40 & $m$ & mo & 1.0 & mo & 0.12 & no & 1.9 & 1.4 \\
\hline 6) & Scale & IV & 0.18 & 0.18 & NO & $\mathbf{m}$ & $\mathbf{M O}$ & $m$ & 0.15 & no & 0.22 & 0.14 & MD & ND & $\mathbf{m o}$ & No & 0.70 & no & 0.62 & 0.32 \\
\hline $\begin{array}{c}\text { AEP } \\
\text { IV } \\
G \\
\text { MEP } \\
\text { MR } \\
\text { MD }\end{array}$ & $\begin{array}{l}\text { Acld extro } \\
\text { Imper lal } \\
\text { The Geyser } \\
\text { Hevada } \\
\text { Amb lent ph } \\
\text { Not applif } \\
\text { Not report } \\
\text { Hot detect }\end{array}$ & $\begin{array}{l}\text { itlon } \\
\text { alley } \\
\text { s } \\
\text { (neu } \\
\text { able } \\
\text { ed }\end{array}$ & proced & & & & & & & & & & & & & & & & & \\
\hline
\end{tabular}


Table 3-8. Alternate Methods Emp loyed in the Extraction Procedure

\begin{tabular}{|c|c|c|c|c|c|c|}
\hline \multirow[b]{2}{*}{ Sample Number } & \multirow[b]{2}{*}{$\begin{array}{l}\text { Grinding } \\
\text { Required }\end{array}$} & \multicolumn{3}{|c|}{ Acid Extraction } & \multicolumn{2}{|c|}{ Neutral Extraction } \\
\hline & & $\begin{array}{l}\text { Extended } \\
\text { Extraction }\end{array}$ & $\begin{array}{l}\text { Centri- } \\
\text { fugation }\end{array}$ & $\begin{array}{c}F \text { inal } \\
\mathrm{pH}\end{array}$ & $\begin{array}{l}\text { Centri- } \\
\text { fugation }\end{array}$ & $\underset{\mathrm{pH}}{\mathrm{Final}}$ \\
\hline G] $(1428)$ & $x$ & & & 6.0 & & 7.0 \\
\hline$G 3(1430)$ & & $x$ & & 5.0 & $x$ & 8.3 \\
\hline G6 (1433) & & & & 5.0 & $x$ & 11.3 \\
\hline G8 $(1435)$ & & & & 4.9 & & 5.1 \\
\hline $69(1436)$ & & & $x$ & 5.2 & $x$ & 6.1 \\
\hline$G 12(1437)$ & & & $x$ & 5.0 & $x$ & 9.4 \\
\hline $616(1441)$ & & & $x$ & 5.2 & $x$ & 8.0 \\
\hline G19-1 (1576) & & & & 4.5 & & 5.7 \\
\hline $620-1(1577 A)$ & & & & 4.9 & & 5.1 \\
\hline $620-1(1577 \mathrm{~B})$ & & & & 4.9 & & 5.1 \\
\hline$G 22-1(1579)$ & & & & 5.0 & & 5.5 \\
\hline $623-1(1580)$ & & & & 3.5 & & 3.9 \\
\hline $624-1(1581)$ & & & & 5.0 & & 9.4 \\
\hline $626-1(1585)$ & & & & 4.9 & & 5.0 \\
\hline $627-1(1587)$ & & & & 5.2 & $x$ & 6.8 \\
\hline$G 30(1668)$ & & $x$ & & 4.9 & $x$ & 9.8 \\
\hline G31 (1669) & & & $x$ & 5.1 & $x$ & $9: 9$ \\
\hline$G 32(1670)$ & & & & 5.2 & $x$ & 9.1 \\
\hline
\end{tabular}


- The acidification of the extracts with nitric acid created interferences in the bor on analysis. Also, the presence of high dissolved solids or organic compounds in some samples introduced additional interferences in boron measurement

- A analyses were performed us ing the graphite furnace for arsenic, cadium, chromium, lead, selenium, and antimony. Problems developed related to inhibition signals (low recoveries, especially lead) and false positive results caused by smoke and high salt content. The samples which were fil tered but not extracted $(1434,1439,1676)$ and the 1437 neutral extract (high organics) tended to produce erratic results in most furnace analyses. Flame analys is produced more reliable results and were relied upon as a check or for quantitation as appropriate

\subsubsection{Organics Analys is}

For three samples - G12, G22-1, G24-1 - known or suspected to have had organic additives introduced, organics analyses were performed. Sample Gl2 was collected at the Class $11-2$ landf $i 11$ in Brawley. This landfill contained a mixture of fresh solid wastes, predominately drilling muds, from the Imperial Valley. Sample G24-1 was a drilling mud sample containing significant amounts of oil. Additives known to be present in this mud were bentonite, sodium hydroxide, calcium hydroxide, sodium tetraphosphate, "Not Plug," and a polymeric material. Sample G22-1 was selected for organics analysis because cationic polyamines and anionic polyacrylamides are added to the iron sludge. These additives facilitate settling of the solids. 
Bioaccumulation potential was determined using the high performance liquid chromotography (HPLC) method specified in the proposed RCRA regulations. Priority pollutants listed in Appendix E were screened by gas chromotography/mass spectroscopy (GCMS). Results of these analyses are presented in Table $3-9$.

\subsubsection{Bulk Composition}

Bulk composition analyses were performed on the total sample and the acid and ambient pH extracts. Metals and silica were measured by AA. Chloride, flouride, sulfate, and sulfide were measured by standard wet chemical analyses. Results are presented in Tables $3-10$ and $3-11$ for the total sample and extract bulk compositions, respectively.

Because the zinc acetate sample preservation technique for sulfide was not employed, it was anticipated that sulfide would not be detected. This expectation was confirmed by the results in the tables.

\subsection{QUALITY CONTROL}

\subsubsection{General Quality Assurance/Quality Control}

Program specific quality control entalied several factors. The objective of the laboratory quality assurance/quality control (QA/QC) program was to meet EPA requirements for precise and accurate results. The principal features of the laboratory $Q A / Q C$ procedures are sumarized below.

Upon receipt at the Acurex Environmental Analytical Laboratory, samples were assigned laboratory identification numbers and logged in. An analysis request form was filled out by the sample control center with the aid of the project chemist. Samples were then placed in the laboratory cold storage room and analysis request forms turned in to the appropriate 
Table 3-9. Organics Analys is Results

Bioaccumulation Potential

\begin{tabular}{|c|c|c|c|}
\hline Sample No. & Extract & $\begin{array}{l}\text { Percent of } \\
\text { Peak Area } \\
\text { Log } P>3\end{array}$ & $\begin{array}{l}\text { Bioaccumulation } \\
\text { Potential }\end{array}$ \\
\hline \multirow[t]{2}{*}{ G12 } & Acid extract & 0 & Negative \\
\hline & Neutral extract & 72 & Positive \\
\hline \multirow[t]{2}{*}{ G22-1 } & Acid extract & 0 & Negative \\
\hline & Neutral extract & 0 & Negative \\
\hline \multirow[t]{2}{*}{ G24-1 } & Acid extract & 0.39 & Negative \\
\hline & Neutral extract & 1.8 & Negative \\
\hline
\end{tabular}

Priority Pollutants Screening

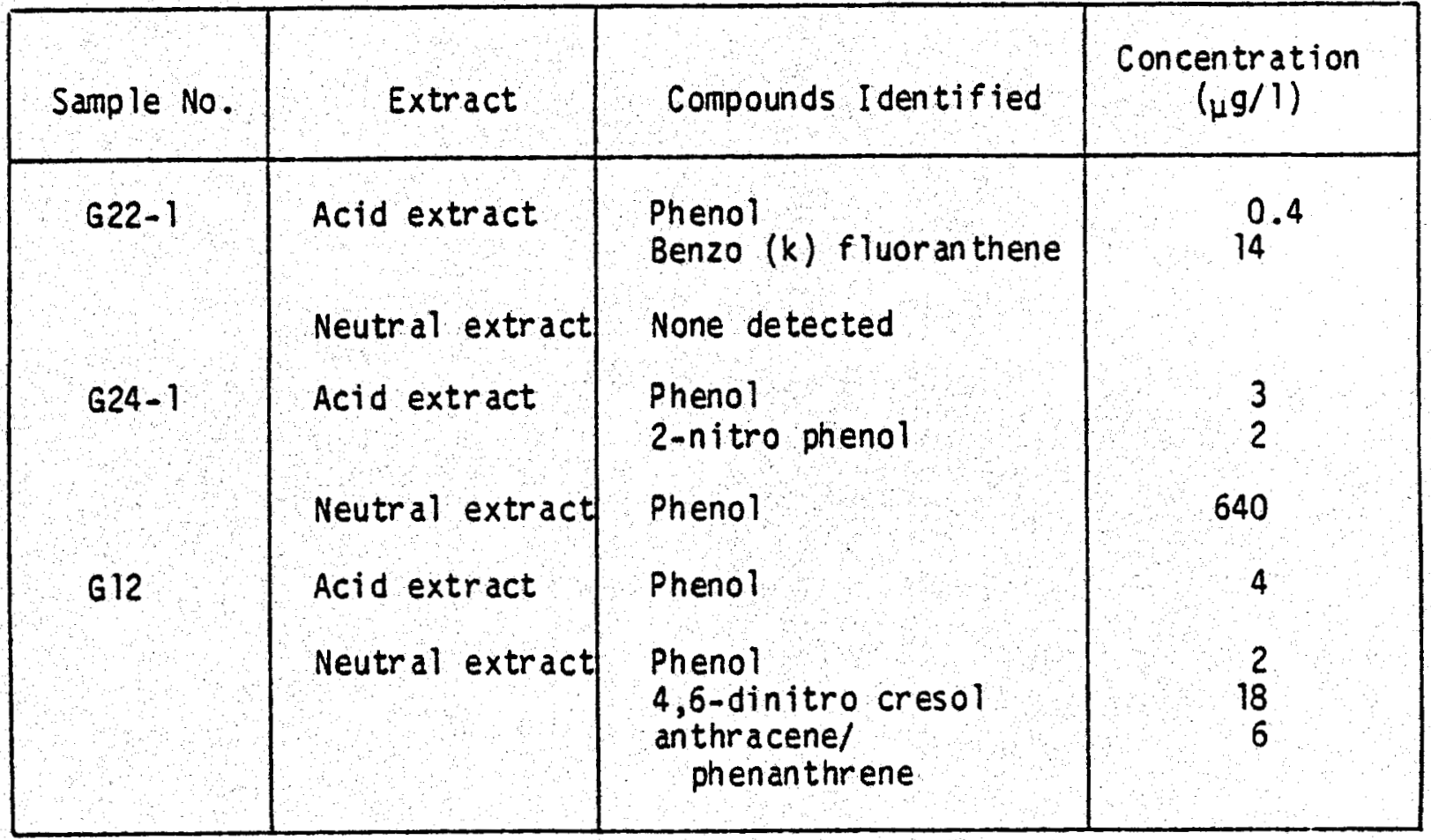


Table 3-10. Bulk Compos ition of Total Sample (Decreasing Weight $\%$ Silica) Silica) and Tentative Identification of Major Componentsa

\begin{tabular}{|c|c|c|c|c|}
\hline $\begin{array}{l}\text { Sample } \\
\text { Number }\end{array}$ & $\begin{array}{c}\text { Sample } \\
\text { Type }\end{array}$ & GRA & x sillica & Other Materials (Approximate $\mathbf{x}$ in porentheses) \\
\hline 69 & Mud & IV & 77 & $\begin{array}{l}\text { Sodium, potass ium, caicium salts (10\%), iron, magnes ium, } \\
\text { aluminum oxides }(10 x)\end{array}$ \\
\hline G16 & Mud & IV & 61 & $\begin{array}{l}\text { Sodium, calcium salts }(15 x) ; \text { fron, magnes ium, aluminum oxides } \\
(20 x)\end{array}$ \\
\hline 66 & Mud & IV & 61 & Calclum salts (10x); iron, magnes fum, aluminum oxtdes (10x) \\
\hline 627 & Mud & G & 59 & Iron, magnes lum, aluminum oxides (15x) \\
\hline 612 & Mixed Sollids & IV & 49 & Calclum salts $(10 x)$; iron, magnes lum, aluminum oxides (15x) \\
\hline 624-1 & Mud & G & 41 & Iron, magnes fum, altuninum oxides $(20 x)$ \\
\hline 630 & Mud & $N$ & 33 & Iron, magnes lum, aluminum oxides (10x) \\
\hline G31 & Mud & 4 & 31 & Calctum salts (10x); fron, magnes ium, aluminum oxides (10x) \\
\hline 632 & Mud & $N$ & 30 & 1 \\
\hline G8 & Sludge & IV & 23 & Sodium, potassium calclum salts $(35 x)$; iron oxides $(10 x)$ \\
\hline 63 & Sediment & IV & 15 & $?$ \\
\hline G23-1 & Sediment & 6 & 12 & Iron oxides $(50 x)$ \\
\hline G1 & Scale & IV & 2 & Calclim carbonate $(70 x)$ \\
\hline 626-1 & Sediment & 6 & $\mathrm{~T}$ & Iron oxides $(70 x)$ \\
\hline 622-1 & Sludge & 6 & 1 & Iron oxides (40x) \\
\hline G19-1 & Sludge & G & $\boldsymbol{I}$ & Iron oxides $(60 x)$ \\
\hline
\end{tabular}

IV Imper lal Valley

G The Geysers

N Nevada

apercentages are on dry weight basis. Oxides are proportioned at approximately 0.3 to 0.5 times element. Percentages in parentheses are on "as received" bas is. 
Table 3-11. Bulk Compos ition of Extracts in Order of Decreasing Chloride Content (mg/l)

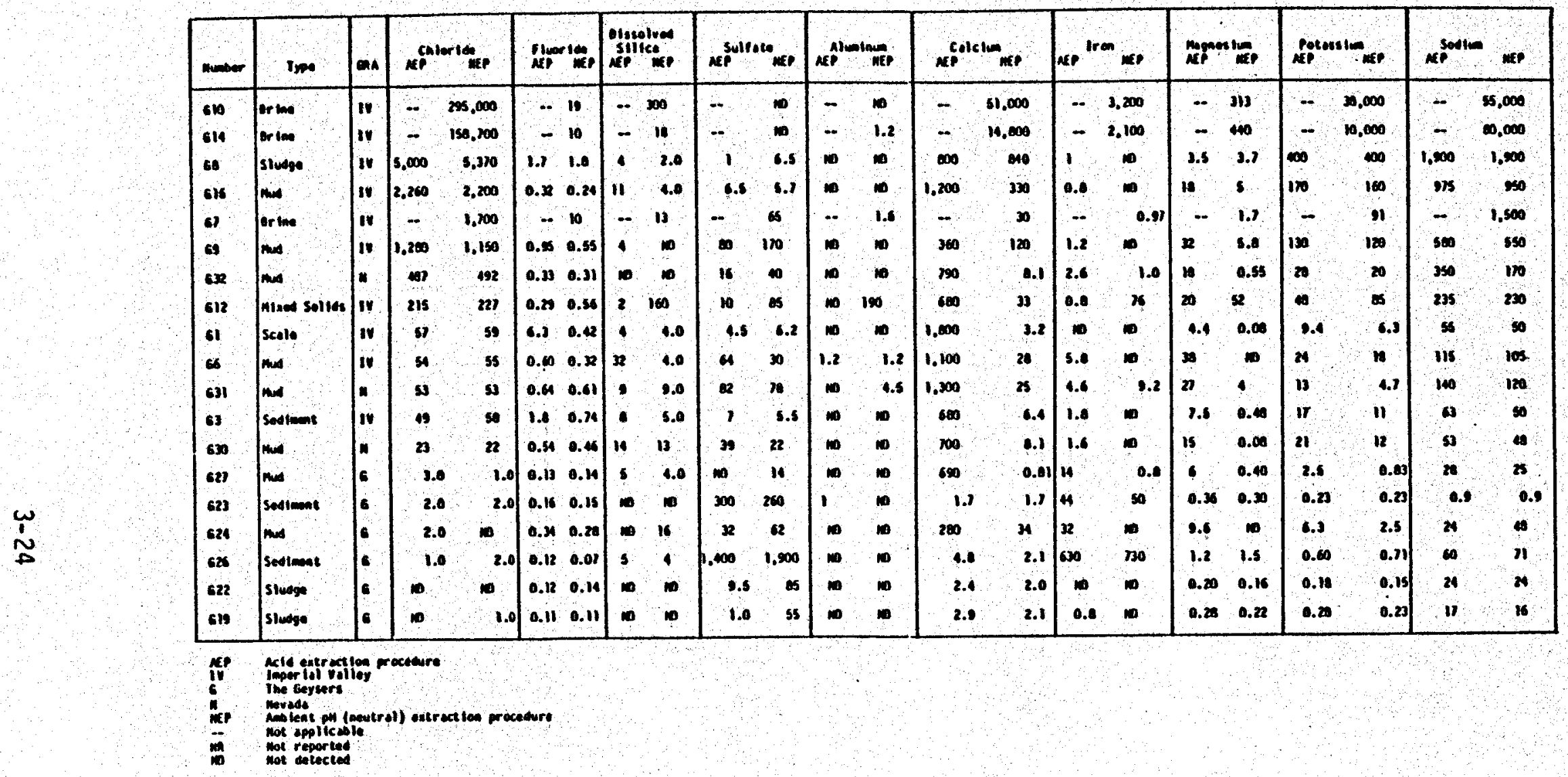


laboratory supervisors. Thus, the samples and required analyses were clearly specified.

The laboratory analysis portion of the QA/QC program involved several phases, from glassware preparation to reporting of results, each controlled by formalized procedures. Any al terations of these procedures was reviewed with the project chemist.

The analytical quality procedures included blank, duplicate, and spike analyses as well as method blanks. Reference samples and calibration standards were of primary standard grade, National Bureau of Standards (NBS) traceable, or of certified purity. Specific results for duplicates and spikes are detailed in the following section. Blank and reference sample analys is results are available, but not included in th is report.

To assure the integrity of the reported results, the project chemist reviewed data with the analysts and discussed the results. Reported values were transcribed directly from the laboratory books to the laboratory reporting form. The project chemist transcribed the analytical data to the report format. The typed draft for review was then checked against the original laboratory forms. By using these specific procedures and several other in tegral parts of the laboratory $Q A / Q C$ program, the quality of the analytical work was documented and assured.

\subsubsection{Program Specific Quality Control}

Quality control generally covered 10 percent of the samples analyzed. There were several areas of quality control beyond the normal QC built into each analytical method. 


\section{Extract Blank}

A OI water blank was carried through the entire extraction procedure including filtration of the sample. The blank was also carried through the priority pollutant analytical scheme. Results for these analyses are shown in Table 3-11. Trace levels of some elements were detected, but in most cases levels were below the accurate quantitation limit of the method. The amounts detected can be attributed to impurities in the 01 water, laboratory contamination, or problems with the method. Spike and Recovery Experiments

For each analysis approxinately four samples were spiked with the element of in terest. Average recovery results are tabulated in Table 3-12. Most of the values were very close to 100 percent and as such are a good indicator of quality results.

\section{Duplicates}

Duplicate determinations were run on about four samples for each analytical procedure. In all cases the duplicates were with in 90 to 110 percent of the original. This provided a good ongoing QC check for each analyst.

Acid and Neutral Extracts

Each of the 18 solid samples was actually extracted twice: once under acid conditions and once under "neutral" conditions; 1.e., without adjus tment to $\mathrm{pH} 5$. For many parameters the concentrations were nearly identical in both extracts. In a sense, every extract was run in duplicate and these correlations are a good QC check.

A cross check on the $Q C$ is obtained by comparing similar samples. Sample G20 was run twice and all results show good agreement. Samples 619 
Table 3-12. Analytical Results for Extract Blank

Sample: Extract Blank

Number: 60

\begin{tabular}{|c|c|c|c|}
\hline Bulk Composition & $\begin{array}{c}\text { Extract } \\
\mathrm{mg} / \mathrm{L}\end{array}$ & Trace Elements & $\begin{array}{c}\text { Extract } \\
\mu \mathrm{g} / \mathrm{L}\end{array}$ \\
\hline Aluminum (AI) & 1 & Arsenic (As) & $<20$ \\
\hline Calcium (Ca) & 0.4 & Barium (Ba) & $<300$ \\
\hline $\operatorname{Iron}(\mathrm{Fe})$ & $<0.2$ & Cadmium (Cd) & $<5$ \\
\hline Magnes ium (Mg) & 0.05 & Chromium (Cr) & $<20$ \\
\hline Potassium (K) & 0.34 & Lead $(P b)$ & 30 \\
\hline Sodium (Na) & 1.5 & Mercury $(\mathrm{Hg})$ & $<1$ \\
\hline Chloride (Cl) & 1.5 & Selenium (Se) & $<20$ \\
\hline Fluoride $(F)$ & 0.14 & Silver $(A g)$ & $<20$ \\
\hline Silica $\left(\mathrm{SiO}_{2}\right)$ & 5 & Antimony (Sb) & $<50$ \\
\hline Sulfate $\left(\mathrm{SO}_{4}\right)$ & $<1.0$ & Beryllium (Be) & $<20$ \\
\hline \multirow[t]{6}{*}{ Sulfide (S) } & $<0.1$ & Boron (B) & 340 \\
\hline & & Copper (Cu) & $<70$ \\
\hline & & Lithium (Li) & $<50$ \\
\hline & & Nickel (Ni) & $<200$ \\
\hline & & Strontium (Sr) & $<500$ \\
\hline & & $\operatorname{linc}(2 n)$ & 30 \\
\hline
\end{tabular}

ORGANICS

Priority Pollutants Acid Fraction 
Table 3-13. Percent Recovery of Spiked Samples

\begin{tabular}{|c|c|}
\hline & Average Percent Recovery \\
\hline \multicolumn{2}{|l|}{ Bulk Composition } \\
\hline Aluminum $(A 1)$ & 102 \\
\hline Calcium (Ca) & 96 \\
\hline Iron $(\mathrm{Fe})$ & 94 \\
\hline Magnes ium $(\mathrm{Mg})$ & 114 \\
\hline Potass ium $(K)$ & 108 \\
\hline Sodium $(\mathrm{Na})$ & 95 \\
\hline Chloride (Cl) & 95 \\
\hline Fluor ide (F) & 102 \\
\hline Silica $\left(\mathrm{SiO}_{2}\right)$ & 106 \\
\hline Sulfate $\left(\mathrm{SO}_{4}\right)$ & 93 \\
\hline Sulfide (S) & - \\
\hline \multicolumn{2}{|l|}{ Trace Elements } \\
\hline Arsenic (As) & 102 \\
\hline Barium (Ba) & 95 \\
\hline Cadmium (Cd) & 90 \\
\hline Chromium ( $\mathrm{Cr}$ ) & 95 \\
\hline Lead $(P B)$ & 55 \\
\hline Mercury $(\mathrm{Hg})$ & 90 \\
\hline Selenium (Se) & 86 \\
\hline Silver (Ag) & 98 \\
\hline Antimony (Sb) & 97 \\
\hline Beryllium (Be) & 91 \\
\hline Boron (B) & 75 \\
\hline Copper (Cu) & 100 \\
\hline Lithium (Li) & 100 \\
\hline Nickel (Ni) & 89 \\
\hline Strontium $(S r)$ & 71 \\
\hline $\operatorname{Zinc}(2 n)$ & 101 \\
\hline
\end{tabular}


and G22 are from identical but separate processes in the same GRA. They also show excellent agreement on EP trace element and bu lk analyses.

\subsection{METHOD DEVELOPMENT NEEDS}

In general, the analytical plan was followed and completed wi thout difficulty. However, there are several analytical areas that require further development.

\subsubsection{Analytical Procedure for Boron}

Analys is of the samples for boron resulted in high blanks and interferences for some samples. The high blank could be explained as contamination from glass containers used in the analys is. A higher detection limit of $2 \mathrm{mg} / \mathrm{L}$ was necessary for three samples (all extracts from the Imperial Valley) due to interferences.

\subsubsection{Analytical Procedure for Sulfide}

A different procedure needs to be developed for sulfide analys is. Sulfide was not detected in any samples because of instability and the lack of a suitable analytical method. To begin with, a separate sample, preserved with zinc acetate, could be split in the field. The bulk composition sample was difficult to analyze by a titration technique because of high turbidity. Analysis of the extracts was not practical since acidification of water containing sulfide releases the sulfide as hydrogen suifide gas.

\subsubsection{Extraction Procedure}

The extraction procedure worked well for most samples, but many samples containing fine clay particles required centrifugation. One sample (1437 neutral extract) could not be filtered after centrifugation. Since the acid extract filterable, it is likely that acidic conditions allow the particles to agglomerate. This sample was collected at a 
1 andf 111 and is representative of samples that may be collected in the future. Any changes in the RCRA procedure to require ambient $\mathrm{pH}$ extraction might result in such problems occurring.

\subsubsection{Brines vs Extracts}

The extraction procedure specifies filtration of liquids and designation of the filtrate as the extract for purposes of determining if the waste meets EP toxicity criteria. According to the EP, an extract of a solid sample is diluted to 20 times the weight of the solid sample. This makes comparison of extracts with filtrates difficult.

\subsubsection{Moisture Content}

Another problem in the RCRA procedure is that the mo is ture content of the sample is not considered. Phase separation is required, but many clays and sludges still contain over 50 percent water. The amount of water to add to an extract should be based on the dry weight of the sample which is subjected to the extraction procedure. 
SECTION 4

RESULTS DISCUSSION

The results presented in Section 3.3 are discussed in this section in terms of the RCRA hazardous waste identification characteristics. Additionally, the results are compared on the basis of geothermal resource area and by type of extraction procedure employed.

\subsection{RCRA HAZARDOUS WASTE REGULATIONS}

There are four RCRA hazardous waste characteristics for which analytical protocols and maximum limits have either been promulgated or proposed by EPA and which have been considered in this study:

- Corrosivity

- Radioactivity

- EP toxicity

- Bioaccumulation potential

Comparison of the 20 samples analyzed against the hazardous waste identification criteria for these characteristics yielded the results presented in Table 4-1. Five samples exceed one or more of these criteria. Sample 68, a clarifier reactor sludge from the Imperial Valley, exceeds the proposed (December 18,1978 ) radium 226 limit. Sample G10, a well brine sample from the Imperial Valley, has a pH below the lower limit for corrosivity and has a barium concentration above the maximum. Sample G12, Brawley Landfil1, showed a positive bioaccumulation potential and 
Table 4-1. Comparison of Analytical Results with RCRA Criteria for Hazardous Wastes

\begin{tabular}{|c|c|c|c|c|c|c|c|c|c|c|c|c|c|}
\hline \multirow{2}{*}{\multicolumn{2}{|c|}{$\begin{array}{l}\text { Sample } \\
\text { Number }\end{array}$}} & \multirow{2}{*}{$\begin{array}{l}\text { waste Chor acter istic: } \\
\text { Constituent Analyzed: } \\
\text { RCRA Linits: }\end{array}$} & \multirow{2}{*}{$\begin{array}{l}\text { Corrosivity } \\
\quad 2 \text { or }=12.5\end{array}$} & \multirow{2}{*}{$\begin{array}{c}\text { Aadioact ivity } \\
\text { Kadium-226 } \\
\geqslant 5 \mathrm{pCi} / 9 \text { or } 50 \mathrm{pCi} / \mathrm{L}\end{array}$} & \multicolumn{8}{|c|}{ EP Toxicity (mg/L) } & \multirow{2}{*}{$\begin{array}{l}\text { Ploaccumblation } \\
\text { potential } \\
\text { log p }>3 \\
\text { positive } \\
\text { Peaks }\end{array}$} \\
\hline & & & & & $\begin{array}{r}\text { As } \\
5.0\end{array}$ & 100.0 & $1.0^{c d}$ & $\begin{array}{r}6 r \\
5.0\end{array}$ & $\begin{array}{c}P D \\
5.0\end{array}$ & $\begin{array}{r}H g \\
0.2\end{array}$ & $\begin{array}{r}5 e \\
1.0\end{array}$ & $\begin{array}{r}\mathrm{Ag} \\
5.0\end{array}$ & \\
\hline $\begin{array}{l}68 \\
610 \\
612 \\
614 \\
616\end{array}$ & $\begin{array}{l}\text { Sludge } \\
\text { orine } \\
\text { Solids } \\
\text { Orine } \\
\text { mud }\end{array}$ & $\begin{array}{l}\text { Values presented for } \\
\text { exceedences of RCRA } \\
\text { limits }\end{array}$ & 1.6 & $\begin{array}{r}1,320 \mathrm{pCi} / \mathrm{h} \\
5.9 \mathrm{pCi} / \mathrm{L}\end{array}$ & 14 & 363 & 4 & & 83 & & 5.1 & & Positive \\
\hline \multicolumn{2}{|c|}{$\begin{array}{l}\text { Remaining is } \\
\text { samples }\end{array}$} & $\begin{array}{l}\text { Ranges presented for } \\
\text { lowest pand nighes } t \\
\text { values (all with in } \\
\text { RCRA Vinitis) }\end{array}$ & $3.7-12$ & $\begin{array}{c}0-3.8 p C i / 9 \\
0 \rho C i / L\end{array}$ & $\left|\begin{array}{c}0.020 \\
0.31\end{array}\right|$ & $<2$ & $\begin{array}{l}<0.005 \\
0.07\end{array}$ & $\begin{array}{c}<0.020 \\
0.98\end{array}$ & $\begin{array}{c}<0.020 \\
0.70\end{array}$ & $<0.00\}$ & $\begin{array}{r}<0.020 \\
0.18\end{array}$ & $<0.02 q$ & $\begin{array}{l}\text { Not anialyzed } \\
\text { or zero }\end{array}$ \\
\hline
\end{tabular}

acid extracts and liquid sample filtrate

$\stackrel{i}{\sim}$ 
further testing is recommended. Sample G14, a well brine collected while a flow test was in progress in the Imperial Valley, exceeds the radioactivity limit and the maximum concentrations for arsenic, cadmium, lead, and selenium. Sample G16, a mud sample from the same well as number G14, exceeds the radioactivity limit. The greater number of RCRA limit exceedences for sample G14 are likely due to the fact that, unlike the other brine samples collected, the salts in $G 14$ had no opportunity to settle out since the sample was collected during a well flow test. None of the remaining 15 samples exhibited pH, radium 226, DWS contaminant values, or $\log p>3$ outside of the nonhazardous ranges for the corrosivity, radioactivity, and EP toxicity, or bioaccumulation potential characteristics, as shown in Table 4-1.

The only two samples (G10 and G14) that exceeded the maximum values for criteria for which final regulations have been promulgated (corrosivity and EP toxicity) were geothermal brine samples from wells in the Imperial Valley. Current regulations adopted by the Regional Water Quality Control Board require that brines produced by geothermal drilling operations which exceed $6,000 \mathrm{ppm}$ total dissolved solids be disposed of at a state hazardous waste disposal site. Well operators in the Imperial Valley generally mainta in segregated drilling mud and brine pits. Muds are disposed of at Class II-2 disposal sites for nonhazardous wastes while brines are sent to Class I hazardous waste sites. Hence, the types of geothermal solid wastes represented by the two brine samples discussed above are already managed as hazardous wastes in the Imperial valley. Three samples (two drilling muds and an iron sulfide sludge) were screened for the 11 acid compounds and the 46 base/neutral compounds listed as priority pollutants by EPA (Appendix E). Each sample gave two 
fractions for analysis by GC/MS. Phenol and phenol derivatives were found in all three samples.

Orilling muds can either be water-based or oil-based. 0il-base muds contain diese 1 fuel and asphalt as we 11 as caustic soda and organic acids to control pH, Orilling muds also contain some of the following additives:

- pH control additives

- Bactericides

- Calcium removers

- Corrosion inhibitors

- Defoamers

- Enulsifiers

- Filtrate reducers

- Flocculants

- Foaming agents

- Plugging additives

- Lubricants

- Surface active agents

- Dispersants

- Viscosifiers

Under the conditions of high temperature common in geothermal drilling operations, these materials can degrade into compounds 1 isted as priority pollutants.

The occurrence of phenols in the drilling mud samples (G12 and Q24-1) may result from direct addition of these compounds, but more likely come from the reaction of caustic soda ( $\mathrm{NaOH})$ with additives containing phenol groups. The alkaline nature of the muds and the final pH of the 
ambient extracts (both 9.4) suggest that the phenol is present as a sodium salt. This is confirmed by the higher concentration of phenol in the ambient extract $(640 \mu \mathrm{g} / \mathrm{L})$ compared to the acid extract $(2 \mu \mathrm{g} / \mathrm{L})$ in G24-1. Polynuclear aromatic compounds (PNA's) were also detected in G-12 and G22-1. For sample G-12, these could easily have come from asphalt (known to contain PNA's) which may have been used in an oil-based drilling mud system.

The presence of a PNA's in the iron sludge (G22-1) cannot be readily explained since the on $1 y$ known additives were polyamines and polyacrylamides.

\subsection{GEOTHERMAL RESOURCE AREA}

Samples were collected from three geothermal resource areas:

- Imperial Valley

- The Geysers

- Northwestern Nevada

A comparison of the analytical results from each of these areas for the RCRA hazardous waste criteria is presented in Table 4-2.

Collectively, the Imperial Valley samples demonstrated the widest range of $\mathrm{pH}$ values and the highest radium 226 levels and DWS contaminant

concentrations. The four samples which met either proposed or promulgated RCRA criteria for hazardous wastes were all from the Imperial Valley. The Geysers and northwestern Nevada samples were overa 11 much lower in radioactivity levels and DWS contaminant concentrations. The Nevada samples, on the whole, were much lower in all respects than the samples from the other GRA's. This may be real or due to the limited number of Nevada samples analyzed. 
Table 4-2. Comparison of Geothermal Resource Areas for RCRA Hazardous Waste Criteria

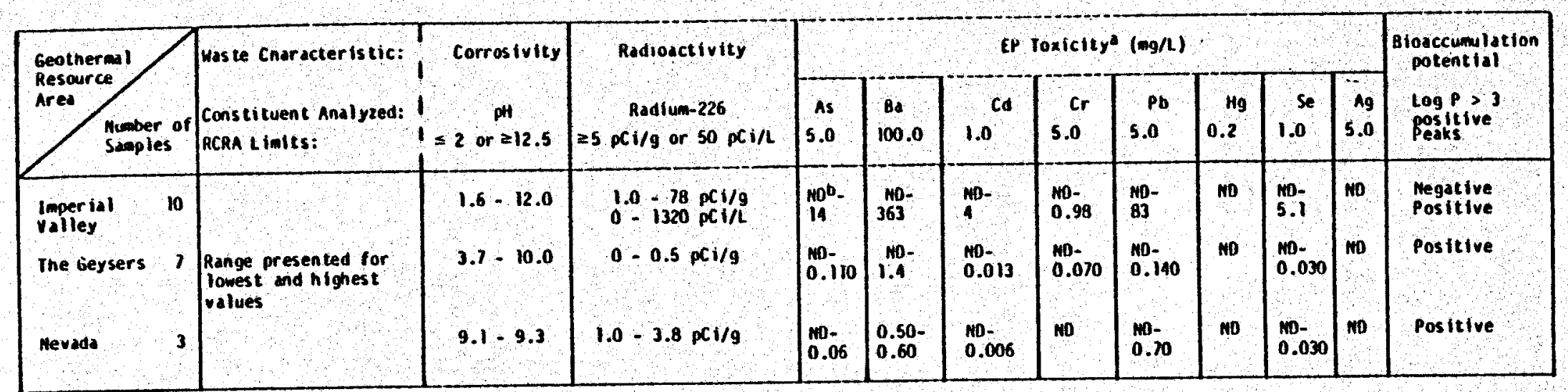

Acid extract (except for liquid samples)

bMot Detected 


\subsection{ACID VERSUS AMBIENT PH EXTRACTION}

The proposed and final RCRA regulations specify an acidic extraction procedure as part of the toxicity analysis. In addition to performing the specified acetic acid EP, a neutral or ambient PH EP using deionized water was conducted. A comparison of the results obtained by the two procedures yields the following:

Average Percentage by Which

DWS Element Neutral EP Results Varied from Acid EP

$\begin{array}{lr}\text { Arsenic } & +32 \\ \text { Barium } & -64 \\ \text { Cadmium } & -32 \\ \text { Chromium } & +28 \\ \text { Lead } & +10 \\ \text { Mercury } & - \\ \text { Selenium } & -12 \\ \text { Silver } & -\end{array}$

Correlations are difficult because in some cases the ambient pH was on the acidic side of neutral. In general, the concentrations were higher in the acid extract. This was most apparent for calcium, magnesium, strontium, and barium. All of these elements form relatively insoluble carbonate salts which are more soluble under acidic conditions. 
APPENDIX A

LETTER REQUESTING PERMISSION TO SAMPLE

A-1 
Gent lemen:

I am writing to you concerning a request to sample solid waste mater ials from your geothermal installations.

Acurex Corporation is currently performing a study for the U.S. Environmental Protection Agency examining the hazardous potential of sol id wastes from geothermal development and operational areas. Mr. Robert P. Hartley of EPA's Off ice of Research and Development, $C$ incinnati, $O H$ is our technical project monitor. The U.S. Department of Energy is jointly funding this effort. Mr. Gerald Katz of the San Francisco Operations Off ice is DOE's technical advisor to Mr. Hartley. This work is being undertaken in cooperation with EPA's Off ice of Sol id Waste. Mr. Will iam Kle in is the contact in that office.

The Resource Conservation and Recovery Act (RCRA) requires that EPA promulgate regulations for the handling and disposal of sol id wastes, including those containing hazardous substances. EPA expects, as part of its obligations under RCRA, to examine the hazardous potential of various solid wastes such as those ar is ing from geothermal act ivities in order to determine under what sections of RCRA these should be controlled. Congress is cons idering a temporary exemption from RCRA for geotherma 1 energy projects while studies to def ine the nature of the was tes are on-going. Eventually, EPA will have to promulgate regulations and/or was te management guidelines for geothermal-produced sol id wastes.

The Acurex study is a screening study, the results of which will be preliminary and will help focus the efforts of an anticipated comprehensive and detailed project to def ine the character of potentially hazardous wastes from geothermal energy development.

Over the next 3 months, we will sample and analyze solid wastes from as representative a group of geothermal sites as access permiss ion and time and budget permit. 
While our study is directed at ass isting EPA in formulating a regulatory direction, it is not intended for use in conjunction with any enforcement proceedings. EPA does not plan to publish the final report of th is prel iminary study al though copies may be released upon request. Duplicates of all samples which we collect will be provided to the facil ity operator for $h$ is independent analys is, if so desired. We will withhold transmitting our analytical results for a reasonable length of time to permit comparison with any independent anal ys is performed.

Signif icant differences in the results obtained which cannot be explained by procedural variations will be noted in our report.

Acurex hopes to conduct the field sampling program during the months of May and June 1980. Types of samples to be collected would include drilling muds, holding and evaporation pond tailings, convers ion process waste streams, and other solids, slurries, and sludges. We would identify the specif ic sampling points dur ing telephone conversations with your designated officials prior to going out in the field.

Acurex will employ sampling and analytical protocols in conformance with EPA's proposed regulations ( 40 CFR 250 in 43 FR 58946) as updated by discuss ions with EPA's Off ice of Sol id Waste and Las Vegas Environmental Mon itoring System Laboratory personnel. Due to the screening nature of our study, only grab samples will be collected.

As part of our sampling program we would like to obta in information relating to waste volumes produced over time, operational status of processes sampled, and current waste handling and disposal practices.

I hope we can reach an agreement regarding access permiss ion and timing that will be mutually acceptable and cons is tent with your needs.

Your earl lest response to th is request would be greatly appreciated. You may reach me with any questions at $415 / 964-3200$, extens ion 3383. Mr. Hart ley's telephone number is $513 / 684-4335$. Mr. Klein's telephone number is 202/755-9200.

Sincerely yours,

Dav id D. Min icucci

OOM: I Project Eng ineer

CC: R. Hartley, EPA-Ci

G. Katz, DOE-San 


\section{ATTACHMENT}

Determining the hazardous character of the samples will cons ist of analyzing for the following constituents:

- Inorganics listed in proposed 40 CFR 250 , Section 250.13 (d) regulations. This 1 ist includes arsen ic, barium, cadmium, chromium, lead, mercury, selen ium, and silver.

- Boron, 2 inc, lith fum, copper, ant imony, nickel, bery 11 ium, and strontium

- Potentially hazardous materials known or suspected to have been added in conversion processes, such as:

- Scale and corrosion inh ib itors

_- Additives for $\mathrm{H}_{2} \mathrm{~S}$ removal processes

- Radium 226 
The Imperial Valley sampling trip was conducted on May 20-23, 1980. A total of 16 samples was collected at the sites identified in Figure $B-1$.

A. Geothermal Test Facility (GTF) -- East Mesa, CA

1. Operated for the U. S. Department of Energy by WESTEC Services, Inc., of San Diego, California

Contact: Bob Sones (714) 356-2956

2. Location - 20 miles east of El Centro near Interstate 8

3. Facilities - Two geothermal fluid wells (Mesa 6-2 and Mesa 8-1) provide hot brine for research projects dealing with heat extraction and energy conversion equipment and materials. A third well (Mesa 6-1) became plugged in 1978. A fourth well (Mesa $5-1$ ) is used for reinjection. Fluids and solids are disposed of in a holding pond onsite. The solids settle and the resulting liquid is reinjected. Complete support services including analytical laboratory and machine shop are at the facility.

4. Operational Status - Facility not in operation since May 5, 1980

5. Sample Collection

Date: May 20, 1980

Sample Numbers: $G-1, G-2, G-3, G-4$, and $G-5$

Weather: Clear, $102^{\circ} \mathrm{F}$

6. Site Diagram (see Figures $B-2$ and $B-3$ ) 


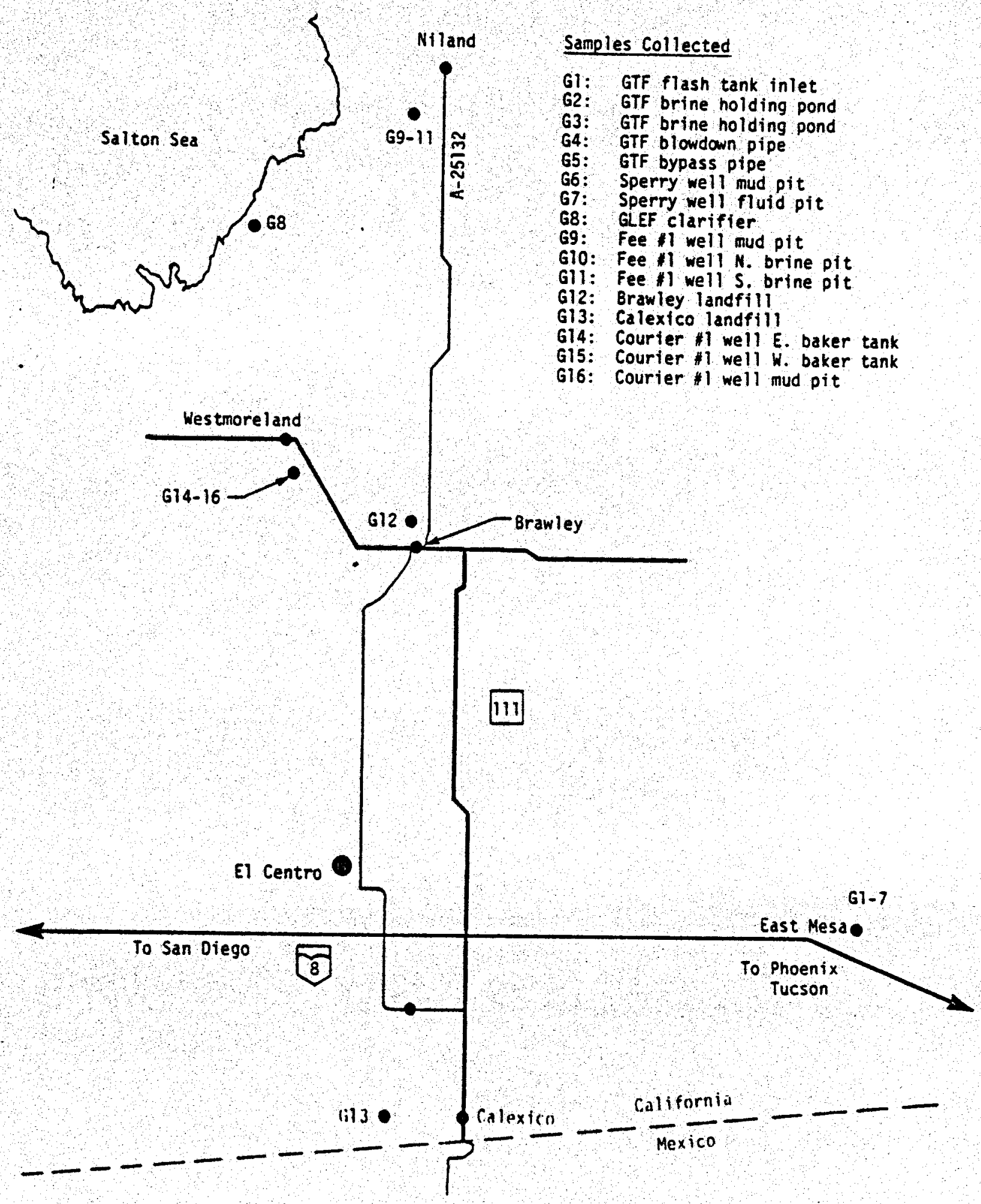

Figure B-1. Imperial Valley Sampling Sites 


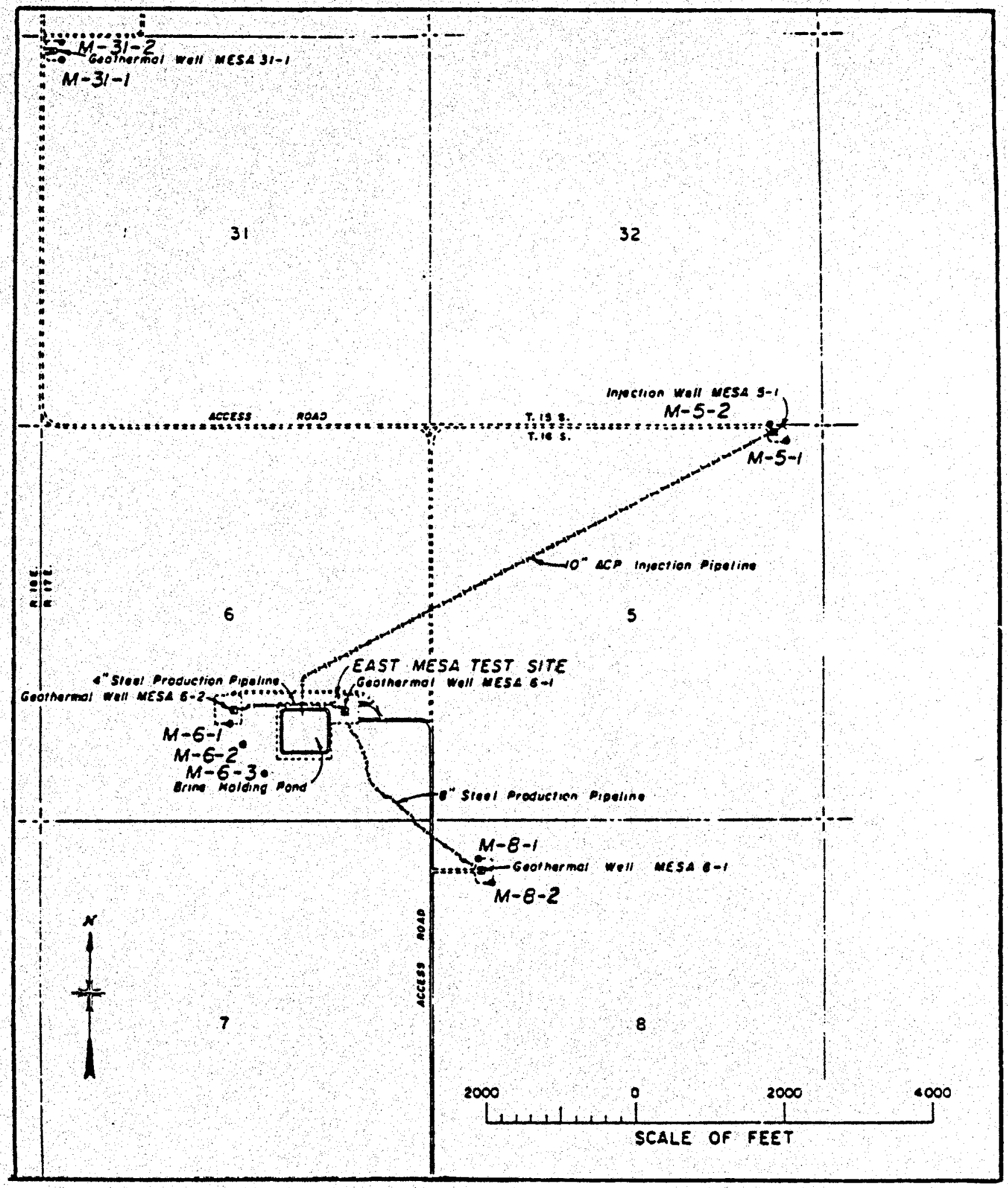

EXPLANATION

- M-5-1 - CHEMICAL MONITORING WELLS

Figure B-2. GTF Area Diagram 


\section{Sample Descriptions}

G-1: Dowell Flash Tank (Scale)

Collected small amount of scale by hand. Tank last cleaned on $1 / 17 / 80$.

G-2: Brine Holding Pond (Sediment)

The pond is $500 \times 500$ feet square with a capacity of 37 -acre feet and a surface area of $6-1 / 2$ acres. Flow curtains control the direction of flow to increase the residence time. Pond level is normally 4 feet (maximum is 7 feet). When sampled, pond level was 2 feet 7 inches. The pond has a 10 mil PVC liner covered with 6 inches of sand. Grab sample was collected near 8-inch diameter blowdown pipe, 10 feet from shoreline, about 6 inches below sediment surface. Used beaker to collect sample. Sample contains some pond weeds and windblown sand.

G-3: Brine Holding Pond (Sediment)

Collected composite sample using beaker at six locations along perimeter about 10 feet from shoreline and 6 inches below sediment surface. Sample contains pond weeds and windblown sand.

G-4: Blowdown Pipe (Scale)

Collected scale from end of 8-inch diameter pipe by mechanical chipping. Scale is mostly calcium carbonate (white in color). 


\section{G-5: Mesa 8-1 Bypass Pipe (Scale)}

A plugged underground 8-inch diameter line which bypassed manifold and directed brine to silencers. Plugged because of flashing in line. Collected grab sample using hand trowel. Scale formed mostly in early 1980.

8. Comments on Sampling and GTF Operation

- Bob Sones donated additional scale samples from flash tanks Mesa 6-2 and 8-1. Approximate 6-month accumulation.

- Brine Holding Pond Used past eight years - never cleaned, 41.9 million gallons input in to pond in 1979. Average total dissolved solids (TDS) is $6369 \mathrm{mg} / \mathrm{h}$.

In $1979,1 \times 10^{6} \mathrm{~kg}$ (1000 tons) of dissolved solids were introduced in to pond.

- Experiments

On site $4-10$

Receiving fluid $0-5$

- Mesa 6-1 plugged

- Temperature of brine at wellhead:

Mes a $6-2-350^{\circ} \mathrm{F}$

Mes a $8-1-300^{\circ} \mathrm{F}$

Downhole temperatures about $30-40$ degrees higher 
B. Sperry Well - East Mesa, CA

1. Test well drilled by Republic Geothermal, Inc. of Sante $\mathrm{Fe}$ Springs, CA

Contact: Dwight Carey (213) 945-3661

2. Location - 20 miles east of E] Centro

3. Facilities - Oual sumps (fluid and mud) and Baker tank remaining at site

4. Operational Status - Experimental well flow tested in March

5. Sample Collection

Date: May 20, 1980

Number: $G-6$ and $G-7$

Weather: Clear, $102^{\circ}$

6. Site Diagram -- See Figure B-4

7. Sample Description

G-6: Sperry Mud Pit (Mud)

Four-corner-compos ite sample collected (see Figure B-4). Used hand trowel to obtain sample 3-6 inches below surface.

G-7: Sperry Fluid Pit (Brine)

Dip sample taken of brown liquid, no salt precipitate in evidence. Used beaker on extension rod.

8. Comments on Sampling and Well Operation

- Most brine went to the GTF brine holding pond 


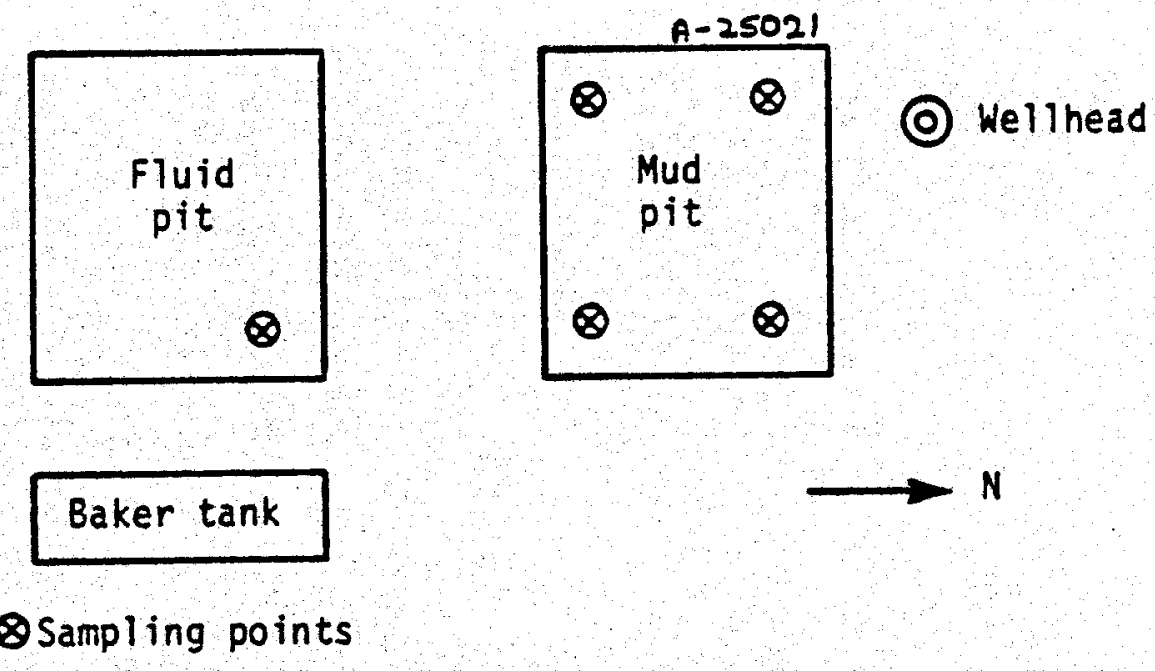

Figure 8-4. Sperry Well 


\section{Geothermal Loop Experimental Facility (GLEF) -- Salton Sea, CA}

1. Operated for the U.S. Department of Energy by Magma Power and San Diego Gas and Electric

Contact: John Feathers tone (714) 348-2424

2. Location - Near Salton Sea at intersection of Gruble and Gentry Roads.

\section{Facilities}

A dismantled power plant and experimental facility. Designed output of $10 \mathrm{MW}$; maximum obtained was $5 \mathrm{MW}$. Operated June to September 1979 for 1700 total hours.

4. Operational Status - Last operation in September 1979

5. Sample Collection

Date: May 21, 1980

Number: $6-8$

Weather: Clear, $90^{\circ} \mathrm{F}$

6. Site Diagram -- Sample collected previously

7. Sample Description

G-8: Clarifier Reactor Sludge Underf low Sludge from filter press which handled solids from 55-foot diameter clarifier reactor. Sample collected August 19, 1979. No additives. Color of sample was dark green in center and brown after exposure to air. Sample had been kept moist in plastic bucket with tight-fitting cover.

8. Comments on Sampling and GLEF Operation

- Facility supplied by Magmamex \#1 well. Well completed in 1972; depth 2100 feet.

- Downhole temperature of $520^{\circ} \mathrm{F}$. 
- A 28 MW power plant is planned for 1982

- Density of brine $9.8 \mathrm{lbs} / \mathrm{gal}$

- Average flow - $525 \mathrm{gpm}$

- Wastes taken to Class I disposal site in San Diego

- Brine contains 50-100 ppm TSS. Clarifier followed by sand/anthractie polish. Reinjected at 5-10 ppm TSS

- Brine 200,000 ppm TDS

- May be economical to recover metals from brine 
0. Fee \#1 Well - N Niland, CA

1. Test well drilled by Republic Geothermal

Contact: Dwight Carey (213) 945-3661

2. Location - Near Pound and English Roads southeast of Niland

3. Facilities - Three sumps and Baker tanks remaining at site

4. Operational Status -- Experimental well, flow tested in April 1980

5. Sample Collection

Date: May 21, 1980

Numbers: G-9, G-10, and G-11

Weather: Clear, $90^{\circ}$

6. Site Diagram -- See Figure $B-5$

7. Sample Descriptions

G-9: Fee \#1 Mud Pit (Mud)

Four-corner-composite sample collected (see Figure B-5).

Some drill cuttings observed in muds.

Used hand trowel to obtain sample 3-6 inches below surface.

6-10: North Brine Pit (Brine)

Dip sample; yellow-green color. Used beaker on extension rod.

G-11: South Brine Pit (Brine)

Dip sample; yellow-green color. Used beaker on extension rod.

8. Comments on Sampling and Well Operation

- Both brine pits lined with large salt crystals

- Left br ine samples at wellhead per arrangements made with

Republic

- Received sample July 8,1980 
(D) Wellhead

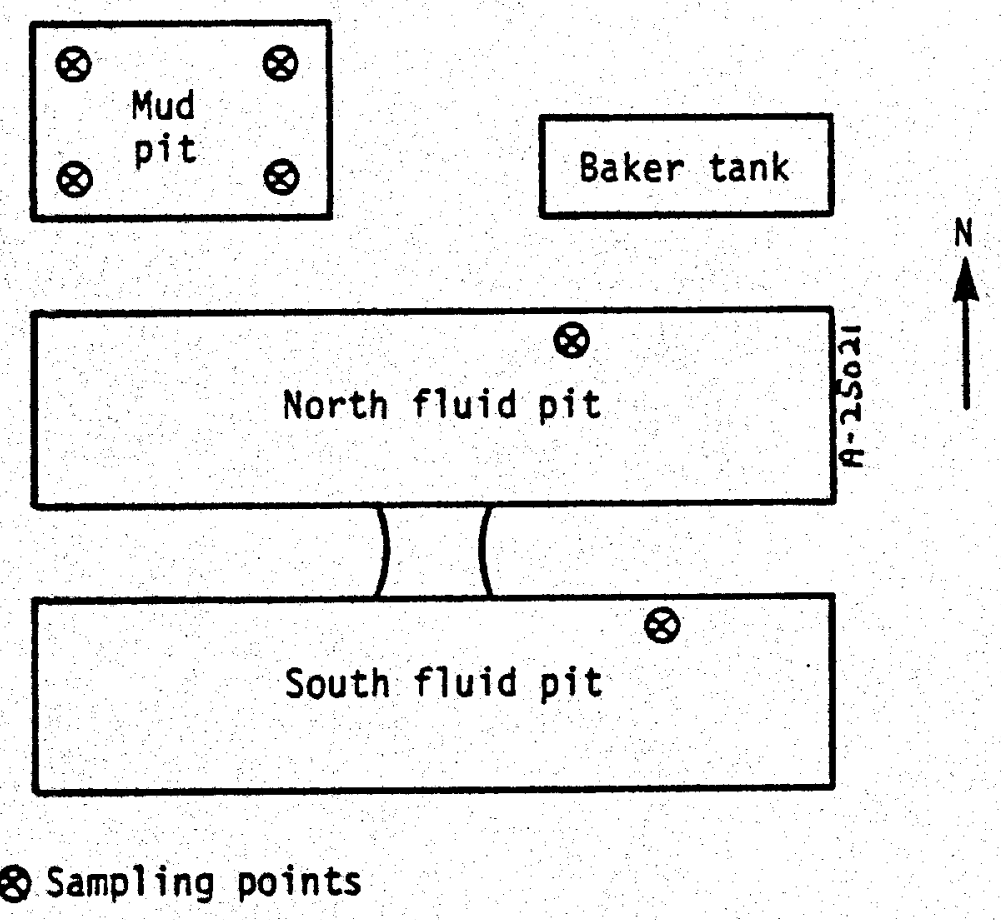

Figure B-5. Fee \#1 Well 
E. Imperial County Landfills - Imperial County, CA

1. Class II-2 solid waste disposal sites operated by the Imperial County Department of Public Works. Contact: Dutch Scholz (714)352-2851

2. Location - Western Avenue in Brawley; Route 98 in Calexico

3. Facilities - Cells for geothermal wastes, principally drilling muds

4. Operational Status - Brawley landf $i 11$ in use; Calexico landfill not used since 1978

5. Sample Collection

Date: May 22, 1980

Numbers: $G-12$ and $G-13$

Weather: Clear, $80-90^{\circ} \mathrm{F}$

6. Site Diagram -- See Figure B-6

7. Sample Descriptions

G-12: Brawley Landf ill (Mixed Solids)

Four-corner-compos ite sample collected (see Figure B-6, A). Fresh wet drilling muds. Used hand trowel to obtain sample $3-6$ inches below surface.

G-13. Calexico Landfill (Mixed Solids) Four-corner-composite sample collected (see Figure B-6, B). Old dry drilling muds. Shallow deposit. Used hand trowel to obtain sample $3-6$ inches below surface.

8. Comments on Sampling and Landfill Operations

- Brine not deposited in these landfills

- Only 8 geothermal wells out of 98 in Imperial County are producing brine at present. 


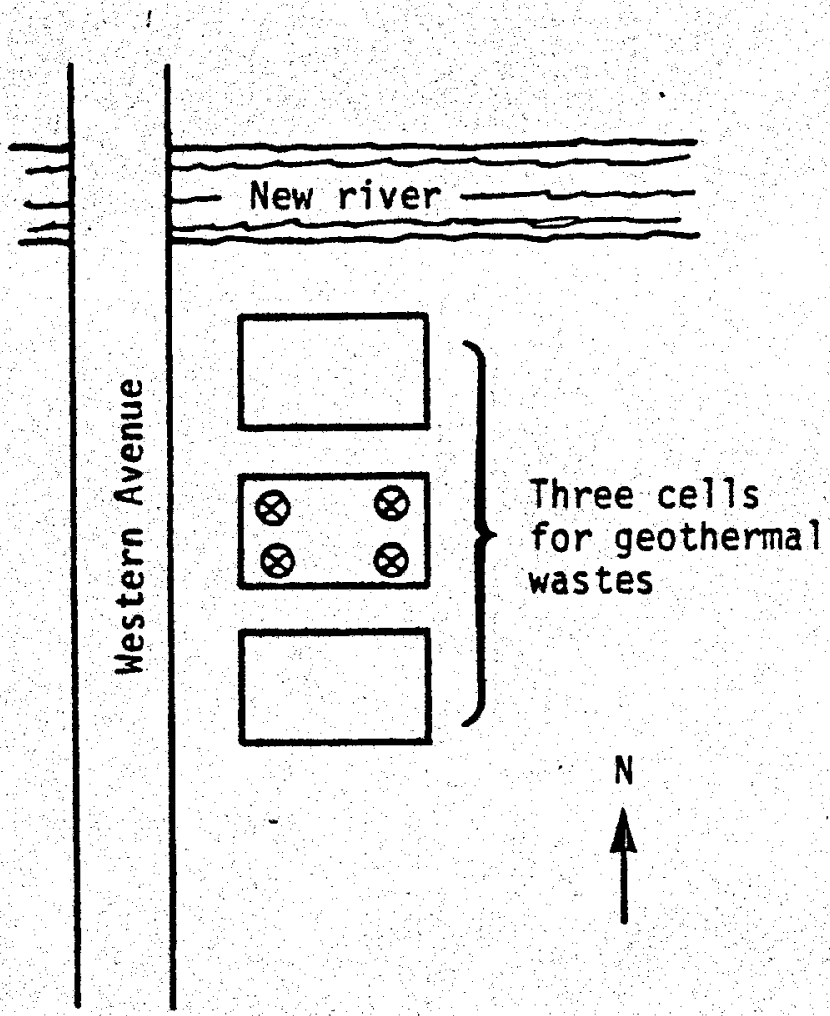

A. Brawley Landfill

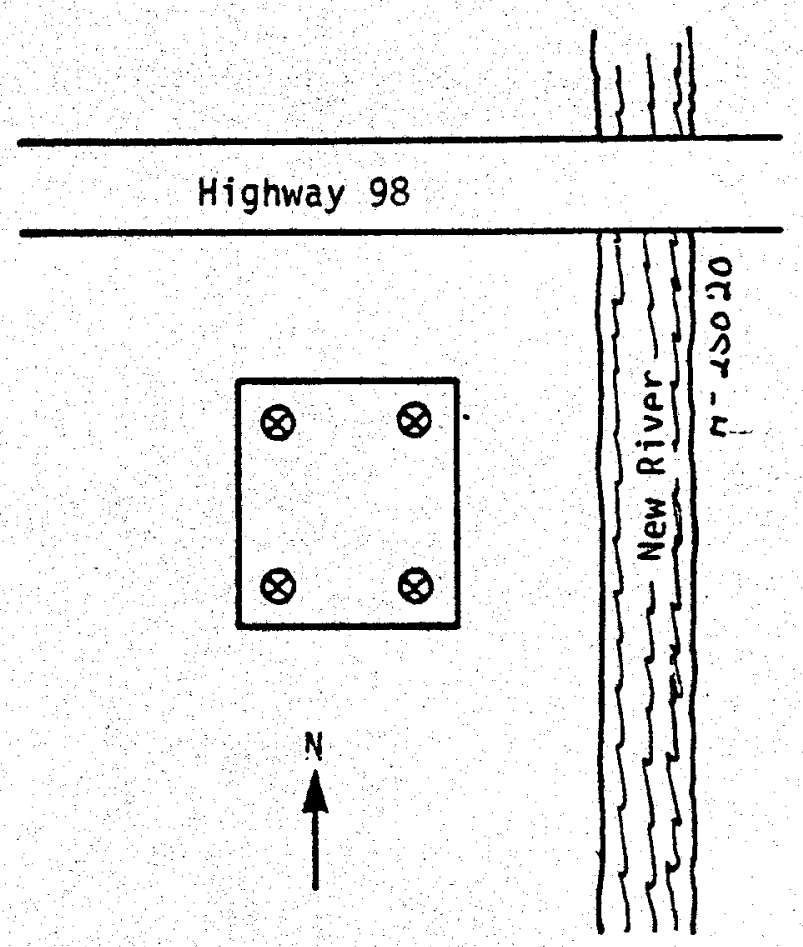

B. Calexico Landfilil

QSampling points

Figure B-6. Imperial County Class II - 2 Disposal Sites. 
- Over 250 applications have been filed with the County for well drilling.

- Brawley middle cell contained 6-feet thick depos it

- Brawley landf 111 about 2 years old 
F. Courier \#1 We11 - Westmorland, CA

1. Test well drilled by MAPCO, Inc. of Tulsa, OK

Contact: Curley Grimlie (714) $353-2620$

2. Location - Near Forrester and Andre Roads, south of Westmor land

3. Facilities -- Much equipment, personnel and Baker tanks onsite

4. Operational Status - Just beginning flow test. Started May 22, 1980

5. Sample Collection

Date: May 23, 1980

Numbers: $G-14, G-15$ and $G-16$

Weather: Clear, $70-80^{\circ} \mathrm{F}$

6. Site Diagram - See Figure 8-7

7. Sample Descriptions

G-14: East Baker Tank (Brine)

Dip sample; yellow color. Used beaker on extension rod.

G-15: West Baker Tank (Brine)

Dip sample; yellow color. Used beaker on extension rod.

G-16: Mud Pit (Mud)

Four-corner-composite. Used hand trowel to obtain sample 3-6 inches below surface.

8. Coments on Sampling and Well Operation

- Samples G-14 and G-15 should be identical

- Producing we $11-10,462$ feet deep

- Injection we $11-8,700$ feet deep

- Started flow test on May 22. Shut down early May 23 bec ause of pump malfunction.

- Only two Baker tanks were full from the test. Approximate ly 10 others were at the site 


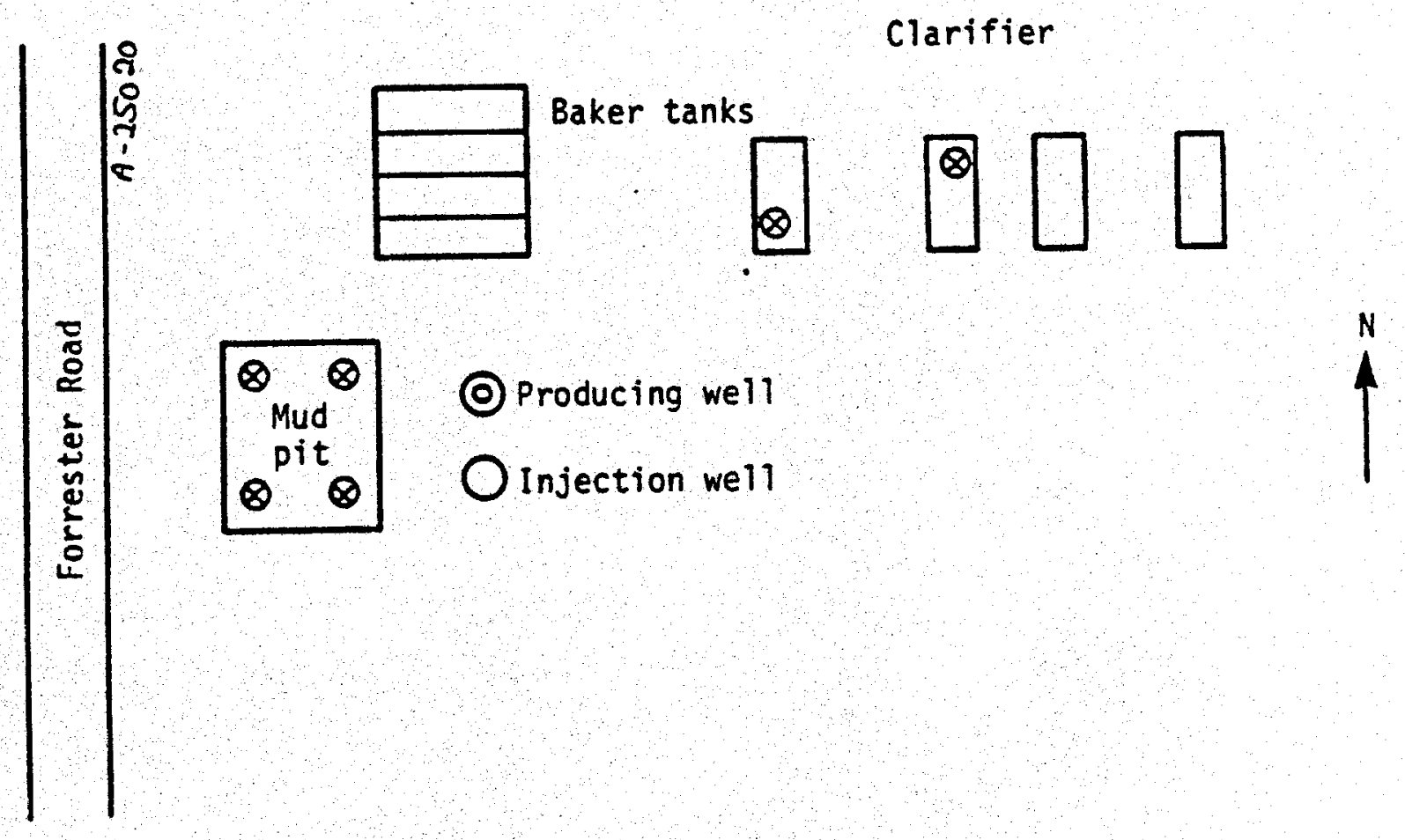

$\otimes$ Sampling points

Figure B-7. Courier \#1 Well

$$
\text { B-19 }
$$


The Geysers sampling trip was conducted on June $3-5,1980$. A total of 13 samples was collected at the sites identified in Figure B-8.

A. Pacific Gas and Electric

1. The Geysers Power $P 1$ ant is operated by PG\&E

Contact: Gordon W. Allen (415) $820-2000$.

2. Location -- Sonoma and Lake counties about 90 miles north of San Francisco

3. Facilities - PG\&E now has 14 units in operation and 2 more are under construction. The first $11 \mathrm{MW}$ un it went in to operation in 1960 and today total capacity is about 800 MW. Approximately 200 wells supply steam.

4. Operational Status - - In operation since 1960

5. Sample Collection

Date: June 3 and 4,1980

Sample Numbers: $G-17$ to $G-23$

Weather: Cool; light rain

6. Site Diagran - - (See Figure B-8)

7. Sample Descriptions

G-17: Unit 15 Stretford Sulfur (Product)

Collected grab sample of molten sulfur during transfer from storage tank to tank truck. Temperature about $120^{\circ} \mathrm{C}\left(280^{\circ} \mathrm{F}\right)$. Yellow-brown color. Sample homogeneous. 


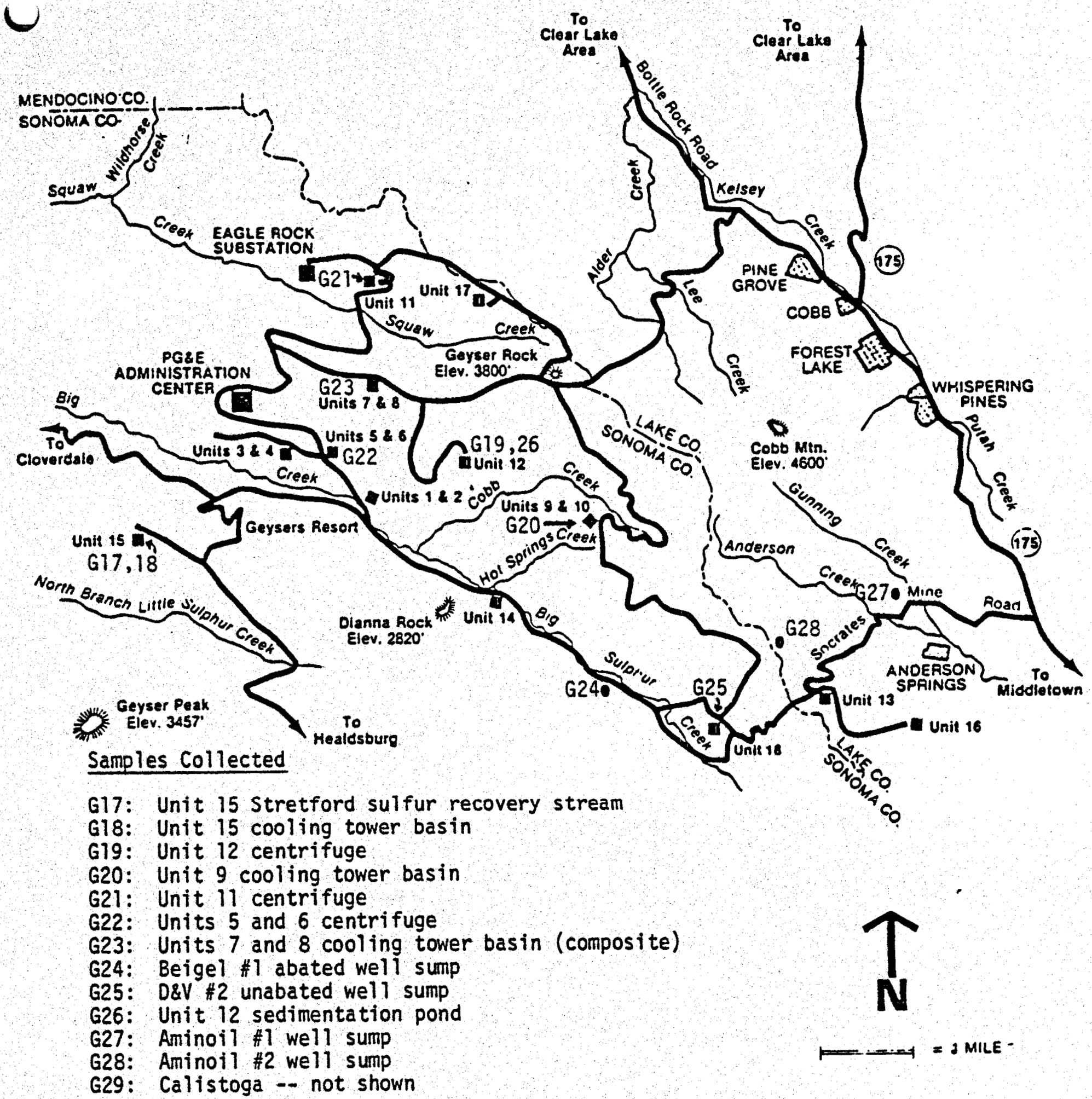

PG\&E

Figure B-8. The Geysers Sampling Sites December Iyrs

Pacific Gas and Electric Company 
G-18: Unit 15 Cooling Tower (Sediment)

Collected grab sample using beaker on extension rod. Very little sediment in basin since unit in operation for only six months. Estimate about 1/4" of sediment on bottom.

G-19: Unit 12 Iron Sludge From Centrifuge (Sludge)

Grab sample collected as sludge drops into hopper. Appeared to be homogeneous.

G-20: Unit 9 Cooling Tower (Sediment)

Unit 10 cooling tower had been cleaned recently and contained very little sediment. Estimate sediment in Unit 9 cooling tower to be in about $8^{\prime \prime}$ thick. Sediment is nonhomogeneous; mixture of red, yellow, and black colored conglomerated material. Collected sample using beaker on extension rod. Difficult to obtain a homogeneous sample even after mixing in the field.

6-21: Unit 11 Iron Sludge From Centrifuge (Sludge) Grab sample collected as sludge drops in to hopper. Appeared to be homogeneous.

G-22: Unit $5+6$ Iron Sludge from Centrifuge (Sludge)

Grab sample collected as sludge drops in to hopper. Should be homogeneous. Normally Units $3+4$ also contribute iron sludge at this location. However, Units $3+4$ were shut down for main tenance.

G-23 Unit $7+8$ Cooling Tower (Sediment)

Collected composite sample using beaker on extension rod. Composite of Unit 7 and Unit 8 . Sediment was about 
4 inches thick and was not as compact as Unit 9. Sample mixed well and was homogeneous.

8. Comments on Sampling and Operation

- Unit 13 not yet producing sulfur - - in operation only a few weeks.

- Units 3,4 and 11 utilize steam containing higher concentrations of sulfur.

- Iron sludge abatement process - cationic polyamine and anionic polyacrylamide added to blowdown water from cooling towers.

- All samples were split. Second splits went to PG\&E for their analysis and third split was held by PG\&E as an archive sample.

- Samples G-20 and G-23 were mixed in a two gallon container and then split. Sample G-20 was difficult to mix adequately in the field. 


\section{B. Union Oil of California}

1. Wells Operated by Union Geothermal Division of Santa Rosa, CA

Contact: Warren Smith (707) 542-9543

2. Location - Sonoma and Lake counties about 90 miles north of San

Francisco

3. Facilities - Various wells throughout the area

4. Operational Status - - Wells being drilled

5. Sample Collection

Date: June 4, 1980

Sample Numbers: $\mathrm{G}-24, \mathrm{G}-25$, and G-26

Weather: Light rain

6. Site Diagrams -- (See Figures B-9, B-10, and B-11)

7. Sample Descriptions

\section{G-24: Abated Sump (Mud)}

Beigel \#1 well will supply steam to Unit 14. Abated for about four hours on June 4. Collected composite sample from four corners of sump using beaker on extension rod (see Figure B-9). Sump contained liquid. Sample composited in two gallon bottle and then split. Sump muds were classified.

\section{G-25 Unabated Sump (Mud)}

D\&V \#2 well will supply steam to Unit 18. Collected composite sample from four corners of sump using beaker on extension rod (see Figure B-10). Sump contained liquid. Sample composited in two gallon bottle and then split. Sump muds were classified. 


\section{(C) Wellihead}

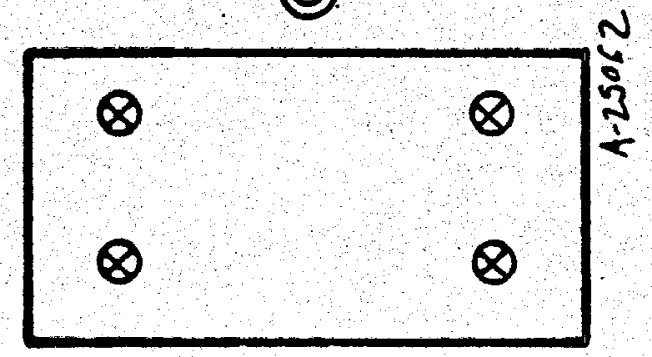

Figure B-9. Beigel \#1 Well

Figure 8-10. D\&V \#2 Well

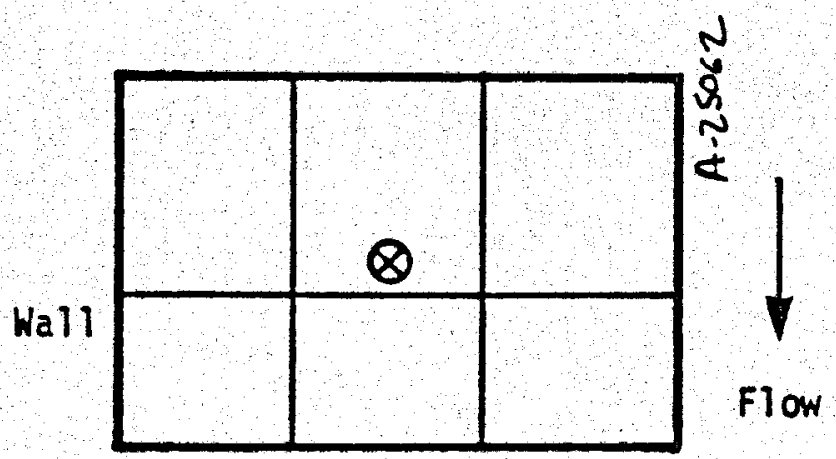

Figure B-11. Unit 12 Sedimentation Pond 


\section{G-26 Unit 12 Sedimentation Pond (Sediment)}

Collected grab sample from middle cell. Water was about

8 feet deep. This made it difficult to sample.

8. Comments on Sampling and Operation

- Sumps are usually covered after use

- Abatement used if concentration of $\mathrm{H}_{2} \mathrm{~S}$ exceeds $5.5 \mathrm{lbs} / \mathrm{hr}$

- Additives used in Beigel \#1:

-- Bentonite

-- Sodium hydroxide

- Calcium hydroxide

-- Sodium tetra-phosphate

- "Not Plug"

-. "Pol ymer"

- All samples were mixed and then split. Second split went to Union and the third to Acurex for archive 


\section{Amino il USA}

1. Well Operated by Amino il U.S.A. of Santa Rosa, CA

Contact: Bill Woods (707) 527-5332

2. Location -- Sonoma and Lake counties about 90 miles north of San Francisco

3. Facilities - Various wells troughout the area

4. Operational Status - Wells being drilled or in operation

5. Sample Collection

Date: June 5,1980

Sample Numbers: $G-27$ and $6-28$

Weather: Clear and $\mathrm{cool}$

6. Site Diagrams - (See Figures $B-12$ and B-13)

7. Sample Descriptions

Q-27 Sump in Mud Drilling Phase (Mud)

The Aminoil \#1 well will supply steam to Un it 19 Evaluation Wel1. Collected compos ite sample from sump at six locations (Figure B-12) us ing beaker-on extens ion rod. Sump contained liquid with brown oil at surface. Sample composited in two gallon bottle and then split. Diff icult to obta in a sample because most solids were in suspension. Depth of well was 5249 feet.

G-28 Sump, Dr 111 ing Completed (Mud)

The Aminoil \#2 well will supply steam to SMUD \#1 power plant scheduled for 1983 completion. Collected compos ite sample using hand trowel -- depth three to six inches. Very little liquid in sump. Sample composited in two gallon bottle and then split. 


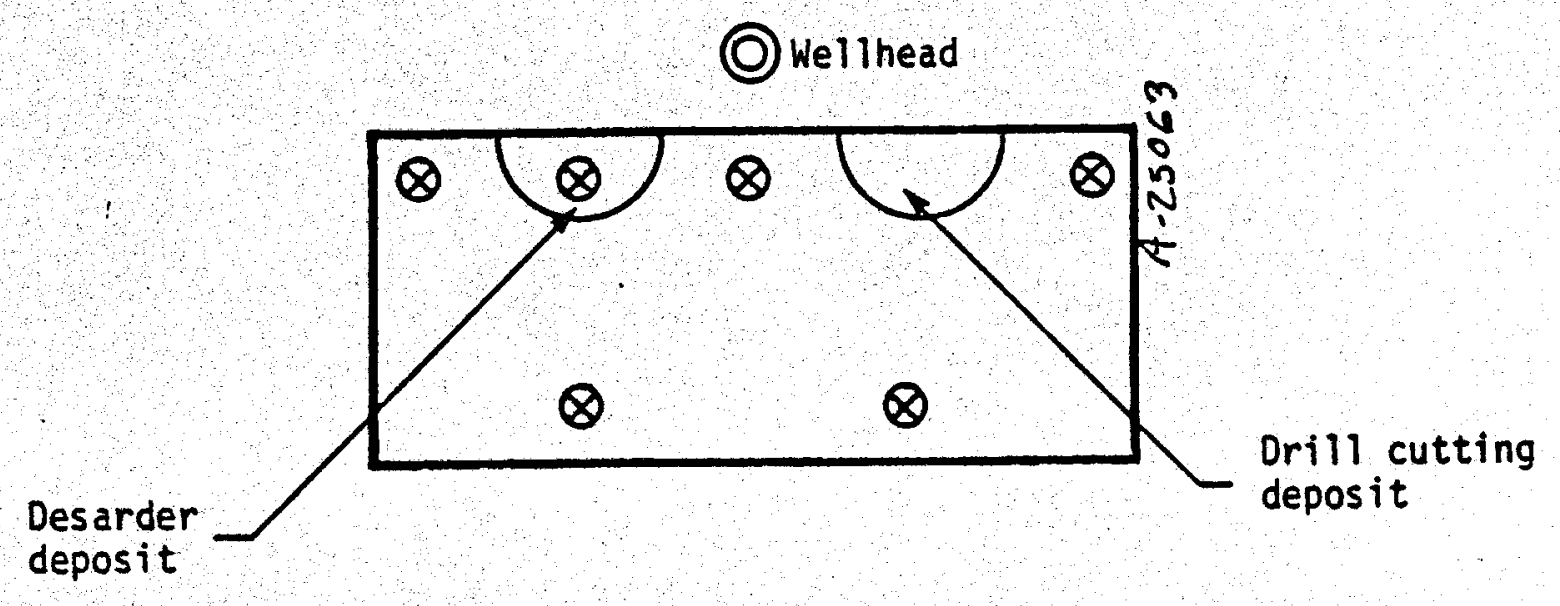

Figure B-12. Aminoil \#1 Well

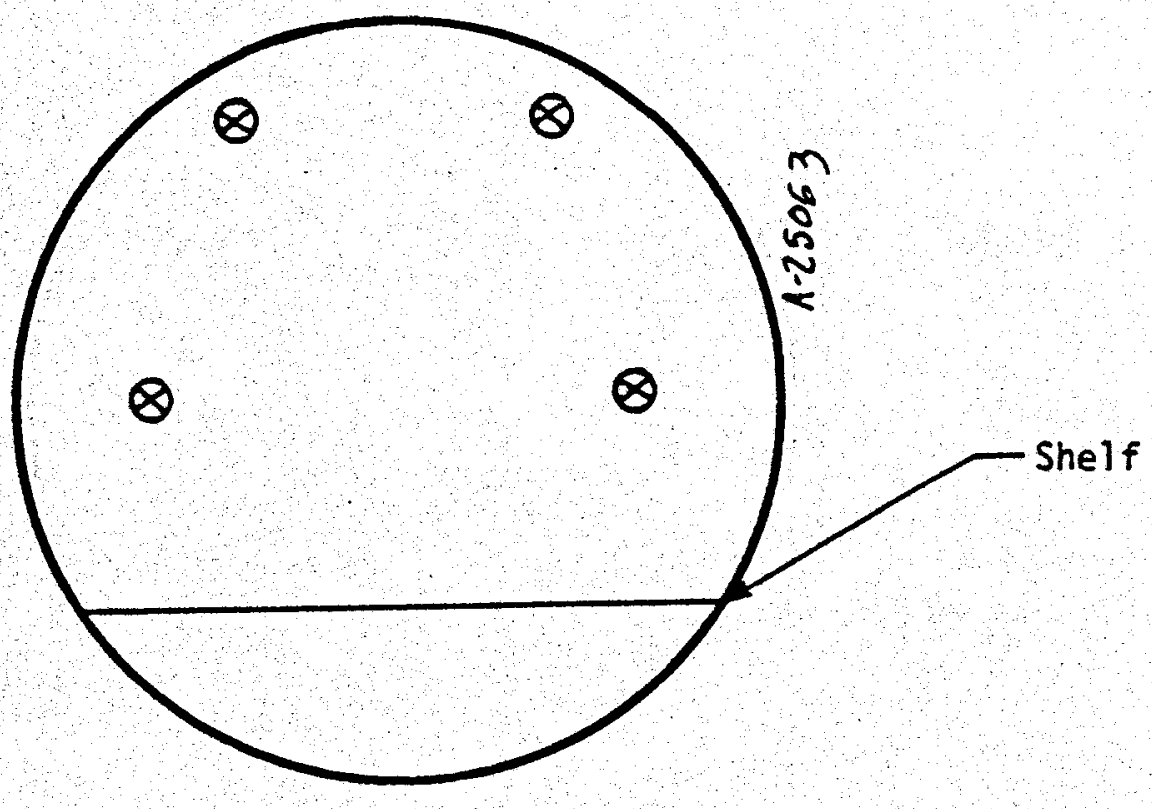

(O) Wellhead

Figure 8-13. Aminoil \#2 Well 
8. Comments on Sampling and Operation

- Aminoil is drilling in an area that has a low $\mathrm{H}_{2} \mathrm{~S}$ concentration (>50 ppm)

- At the site, Aminoil requested a split sample. They provided the ir own bottles 
D. Calistoga Geothermal Deposit

1. Geologic surface expression thought possibly to be a deposit of geothermal brines by the California Division of Mines and Geology headquartered in Sacramento, $C A$

- Contact: Les Youngs (916) 322-8078

2. Location - On west side of Tubbs Lane between Route. 128 and Grant Street in Calistoga, $\mathrm{CA}$

3. Sample Collection

Date: June 5,1980

4. Sample Description

At first, Les Young thought the rock outcropping was a geothermal deposit. However, upon closer examination its origin is uncertain and it may be volcanic. A sample was collected using a rock hammer. 
The Nevada sampling trip was conducted on July 1-2, 1980. A total of four samples was collected at the sites identified in Figure B-14.

1. Orilling operations in western Nevada conducted by Phillips Petroleum Company of Reno, NV

Contact -- Bob Forest (702) $786-2273$

2. Location - Three locations south and east of Reno, Nevada

3. Facilities -- Various wells throughout the Reno area

4. Operational Status - Evaluation wells

5. Sample Collection

Date: July $1-2,1980$

Sample Numbers: G-30, G-31, G-32, and G-33

Weather: Clear and hot

6. Site Diagrams - (See Figures B-15, B-16, and B-17)

7. Sample Descriptions

G-30: Phillips Steamboat \#1 Well (Mud)

Well was being flow tested. Sump contained liquid. Collected composite sample using beaker on extension rod and hand trowel

G-31: Phillips Humbolt House (Mud)

Ory sump. Collected composite sample 3 to 6 inches below surface using hand trowel

G-32: Phillips Desert Peak, Primary Sump (Mud)

Collected composite sample 3 to 6 inches below surface using hand trowel. 


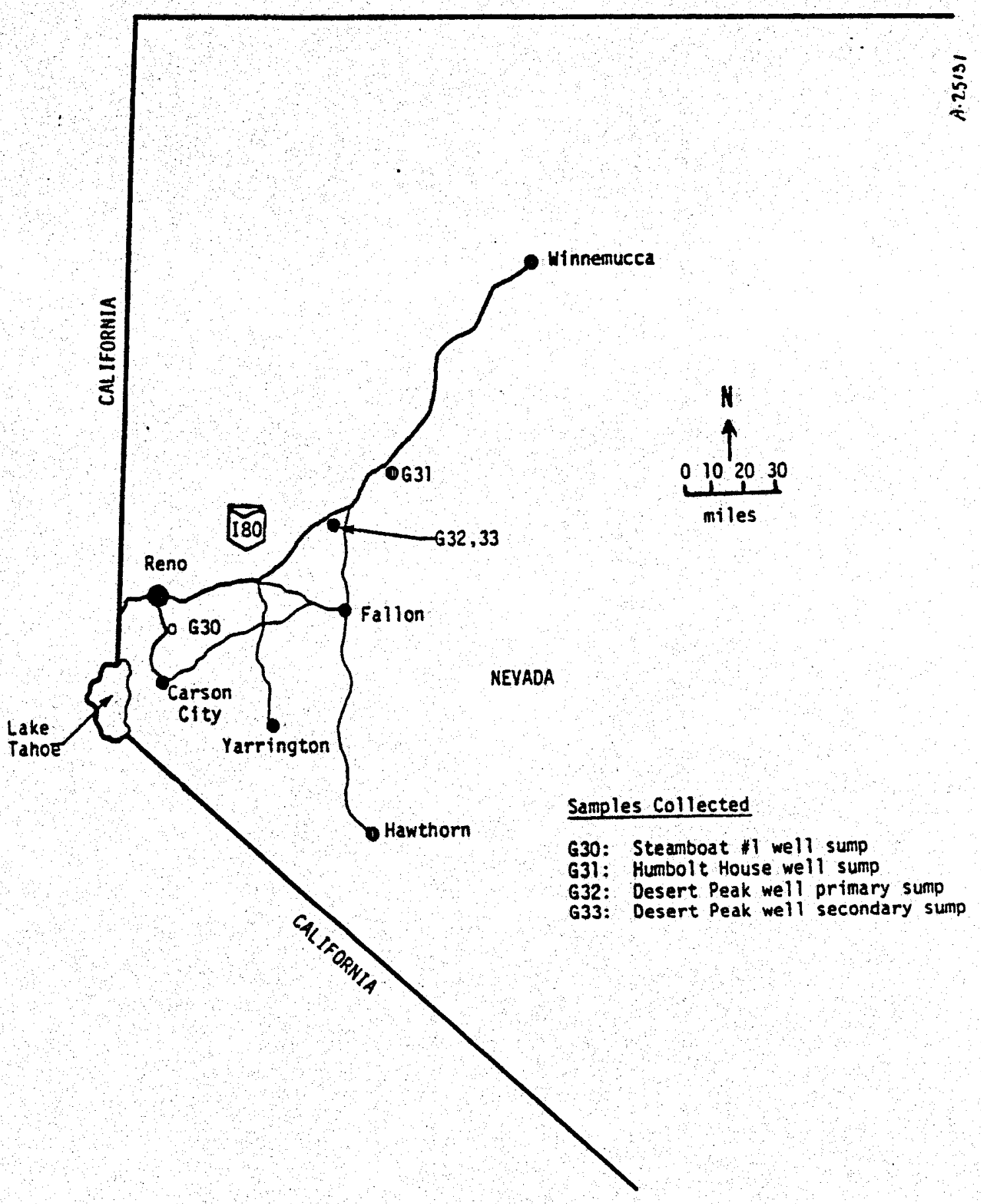

Figure B-14. Nevada Sampling Sites 


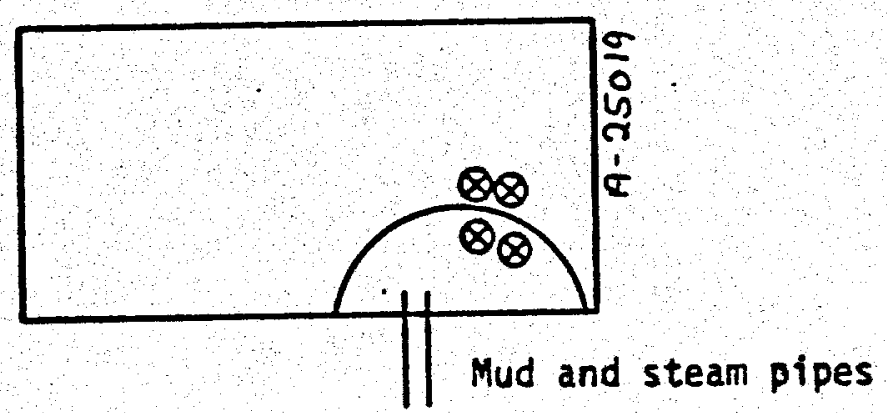

()

Figure B-15. Steamboat \#1 Well

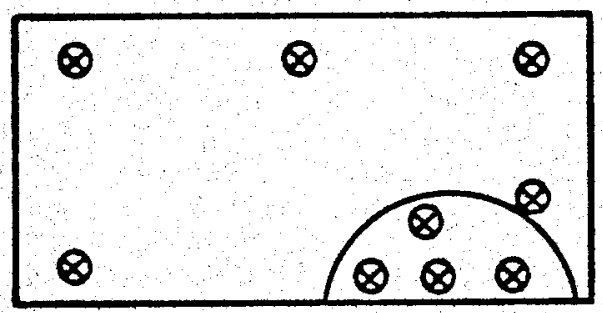

()

Figure B-16. Humbolt House We11

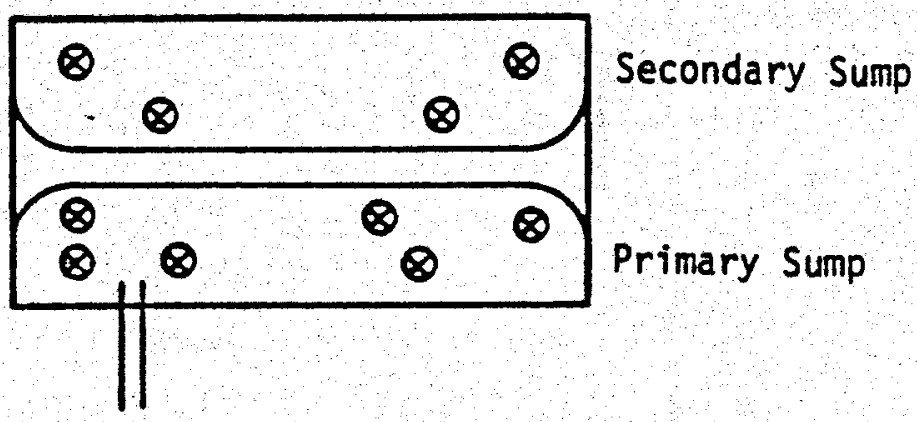

(C)

Figure B-17. Desert Peak Well 
G-33 Phillips Desert Peak, Secondary Sump (Mud)

Collected composite sample 3 to 6 inches below surface using hand trowel. 
APPENDIX C

SPECIFIC ANALYTICAL METHODS

Acurex used EPA approved analytical methods for this program as sumarized in Table C-1. Complete descriptions of the various analyses performed are presented below.

1. Metals

Metals were determined by atomic absorption (AA) spectroscopy using a Perk in-Elmer Model 460 equipped with heated graphite analyzer, hydride system and 30 lamps. Samples were digested with nitric acid or mixed acids if required. To obtain part per billion ( $p p b)$ detection limits for some trace elements, furnace techniques were used. Mercury was determined by the cold vapor technique.

\section{Chloride}

For the total sample, chloride was determined by potentiometric titration with silver nitrate solution. The digested sample was titrated to an end point which gave the greatest change in potential per unit volume of silver nitrate added.

Extracts were titrated with silver nitrate using potassium chromate as an indicator. 
Table C-1. Sumary of Analytical Methods

\begin{tabular}{|c|c|c|}
\hline \multicolumn{3}{|c|}{ Bulk Composition - Total Sample } \\
\hline $\begin{array}{l}\text { Alumi num }(A)) \\
\text { Calcium ( } \mathrm{Ca}) \\
\text { Iron ( } \mathrm{Fe} \text { ) } \\
\text { Magnesium }(\mathrm{Mg}) \\
\text { Potassium }(K) \\
\text { Sodium }(\mathrm{Na})\end{array}$ & $\begin{array}{l}\text { AA, Direct Aspiration } \\
\text { AA, Direct Aspiration } \\
\text { AA, Direct Aspiration } \\
\text { AA, Direct Aspiration } \\
\text { AA, Direct Aspiration } \\
\text { AA, Direct Aspiration }\end{array}$ & $\begin{array}{l}\text { Method } 202.1 \text { (1) } \\
\text { Method 215.1 (1) } \\
\text { Method 236.1 (1) } \\
\text { Method 242.1 (1) } \\
\text { Method 258.1 (1) } \\
\text { Method 273.1 (1) }\end{array}$ \\
\hline $\begin{array}{l}\text { Chloride (C1) } \\
\text { Fluoride }(F) \\
\text { Silica }\left(\mathrm{SiO}_{2}\right) \\
\text { Sulfate }\left(\mathrm{SO}_{4}\right) \\
\text { Sulfide }(S)\end{array}$ & $\begin{array}{l}\text { Potentiometric } \\
\text { Electrode } \\
\text { AA, Direct Aspiration } \\
\text { Gravimetric } \\
\text { Titrimetric (Iodine) }\end{array}$ & $\begin{array}{l}\text { Method 408.C (2) } \\
\text { Method 414.8 (2) } \\
\text { Perkin-Elmer (3) } \\
\text { Method 427.A (2) } \\
\text { Method 428.0 (2) }\end{array}$ \\
\hline \multicolumn{3}{|c|}{ Bulk Composition - Extracts } \\
\hline $\begin{array}{l}\text { Aluminum (A]) } \\
\text { Calcium (Ca) } \\
\text { Iron ( } F e \text { ) } \\
\text { Magnesium (Mg) } \\
\text { Potassium (K) } \\
\text { Sodium ( } \mathrm{Na} \text { ) }\end{array}$ & $\begin{array}{l}\text { AA, Direct Aspiration } \\
\text { AA, Direct Aspiration } \\
\text { AA, Direct Aspiration } \\
A A \text {, Direct Aspiration } \\
\text { AA, Direct Aspiration } \\
\text { AA, Direct Aspiration }\end{array}$ & $\begin{array}{l}\text { Method 202.1 (1) } \\
\text { Method 215.1 (1) } \\
\text { Method 236.1 (1) } \\
\text { Method 242.1 (1) } \\
\text { Method 258.1 (1) } \\
\text { Method 273.1 (1) }\end{array}$ \\
\hline $\begin{array}{l}\text { Chloride }(\mathrm{Cl}) \\
\text { Fluoride }(\mathrm{F}) \\
\text { Silica }\left(\mathrm{SiO}_{2}\right) \\
\text { Sulfate }\left(\mathrm{SO}_{4}\right) \\
\text { Sulfide }(\mathrm{S})\end{array}$ & $\begin{array}{l}\text { Argentometric } \\
\text { Electrode } \\
\text { AA, Direct Aspiration } \\
\text { Turbidimetric } \\
\text { Methylene Blue }\end{array}$ & $\begin{array}{l}\text { Method 408.A (2) } \\
\text { Method 414.B (2) } \\
\text { Perkin-E } 1 \text { mer (3) } \\
\text { Method } 427 . C \text { (2) } \\
\text { Method } 428 . C \text { (2) }\end{array}$ \\
\hline
\end{tabular}


Table $\mathrm{C}-1$. Continued

Trace Elements - Extracts

Arsenic (As)

Barium ( $\mathrm{Ba}$ )

Cadmium (Cd)

Chromium (Cr)

Lead $(\mathrm{Pb})$

Mercury $(\mathrm{Hg})$

Selenium ( $\mathrm{Se}$ )

Silver (Ag)

Antimony ( $S b$ )

Beryllium (Be)

Boron (B)

Copper (Cu)

Lithium ( $L i$ )

Nickel (Ni)

Strontium (Sr)

Zinc $(Z n)$
AA, Furnace

AA, Direct Aspiration

AA, Direct Aspiration and Furnace

AA, Direct Aspiration and furnace

AA, Direct Aspiration and Furnace

AA, Cold Vapor

AA, Furnace

AA, Direct Aspiration

AA, Furnace

AA, Direct Aspiration

Colorimetric, Curcumin

AA, Direct Aspiration

AA, Direct Aspiration

AA, Direct Aspiration

AA, Direct Aspiration

$A A$, Direct Aspiration
Method 206.2 (1)

Method 208.1 (1)

Methods 213.1 and 213.2 (1)

Methods 218.1 and 218.2 (1)

Methods 239.1 and 239.2 (1)

Method 245.1 (1)

Method 270.2 (1)

Method 272.1 (1)

Method 204.2 (1)

Method 210.1 (1)

Method 405.A (2)

Method 220.1 (1)

Perkin-Elmer (3)

Method 249.1 (1)

Perkin-Elmer (3)

Method 289.1 (1)

Other Parameters

Corrosivity

Moisture

TSS

Radium 226
Electrode

Gravimetric

Gravimetric

Scintillation or

Deemanation
Method 150.1 (1)

Method 208.A (2)

Method 208.0 (2)

Method 706 (2)

Priority Pollutants - - Acid and Base/Neutral Compounds

Solvent Extraction, GC/MS

Federal Register (4)

Bioaccumulation Potential

HPLC, octanol/water partition coefficient

Federal Register (5)

EP Toxicity

Extraction Procedure

Federal Register (6) 


\section{References}

(1) "Methods for Chemical Analys is of Water and Wastes," EPA-600/4-79-020, March 1979.

(2) "Standard Methods for the Examination of Water and Wastewater," 14 th -Edition, 1975. APHA, AWWA, WPCF, Washington, D.C.

(3) "Standard Operating Conditions Manual," Perkin-Elmer Corporation, Norwalk, Connecticut, Sep tember 1976.

(4) Federal Register, 40CFR Part 136, Volume 44, Number 233, December 3, 1979.

(5) Federal Register, 40CFR, Part 250, Volume 43, Number 243, December 18, 1978.

(6) Federal Register, 40CFR, Part 261, Appendix II, Volume 45, Number 98, May 19, 1980. 


\section{Fluoride}

The total sample was first distilled to separate fluoride from interferences. The resulting fluoride in the distillate was measured using a specific ion electrode. Extracts were analyzed directly using the electrode.

4. Silica

Solid samples were first digested. All digests and extracts were analyzed by flame AA. Results are reported as $\mathrm{SiO}_{2}$.

5. Sulfate

Solid samples were digested and the sulfate precipitated with barium chloride. The resulting barium sulfate was determined gravimetrically in the extracts. Low levels of sulfate were measured turbidimetrically as barium sulf ate using a nephelometer.

6. Sulfide

Samples were not preserved with zinc acetate and therefore levels were expected to be low. Aliquots of the solid samples in water were taken and treated with excess fodine. These were then back titrated with sodium thiosulfate. Extracts were determined colorimetrically as methylene blue at a wavelength of $625 \mathrm{~mm}$ on a Hitachi spectrophotometer. 7. Boron

Boron in the extracts was determined using the Curcumin method. Boron reacts with curcumin to form a red-colored product called rosocyanine. The color was measured photometrically.

8. Priority Pollutants

A 1-liter sample was extracted with methylene chloride using separatory funnel techniques. Because of problems with emulsions, one sample was extracted using a liquid-liquid continuous extractor. In each 
case, the extract was dried over sodium sulfate and concentrated to a volume of $1 \mathrm{nl}$ in a Kuderna-Danish evaporator. Each sample gave two fractions (base/neutral and acid) which were analyzed by GC/MS following Method 625 (Federal Register, Vo1. 44, \#233, p. 69540, December 3, 1979). 9. Bioaccumulation Potential

Specific correlations exist between octanol/water partition coefficients and bioconcentration in fish. High performance liquid chromatography is used to determine this bioaccumulation potential. First, the instrument is calibrated with a series of compounds with known partition coefficients. If the organic compounds in an extract have partition coefficients above a designated level, the sample has a positive bioaccumultion potential.

10. Corrosivity

The $\mathrm{pH}$ was measured using an Orion Model $701 \mathrm{pH}$ Meter. Liquids were measured directly. Ten grams of solids (as received) were slurried with $200 \mathrm{ml}$ of DI water for 12 hours and then the $\mathrm{pH}$ was measured. 11. Moisture

A portion of the sample was dried at $105^{\circ} \mathrm{C}$ for 12 hours and the residue determined gravimetrically.

12. Total Suspended Solids (TSS)

A known volume of sample was filtered and the residue dried at $105^{\circ} \mathrm{C}$ for 12 hours. A gravimetric determination gave the TSS.

13. Radium 226

Radium 226 in solids was determined by gama spectroscopy using a Ge(Li) scintillation counter and the radium 226 in liquid samples was determined by deemanation techniques. 
14. Toxicity Extraction Procedure Approximately $150 \mathrm{~g}$ of a representative sample were used in this procedure. The solid phase was extracted in an Acurex Rotary Extractor for 24 hours at PH 5 to give the acid extract. Each sample was also extracted with DI water with no adjustment of the pH. This extract became the neutral extract. In some cases the samples were difficult to filter and centrifugation was necessary. 
A Geothermal Analytical Data form was prepared for each sample analyzed. These are presented on the following pages. Abbreviations used on the forms include:

NA - Not applicable

Int - Interference (reporting of results not possible)

The following notes also apply:

- Total sample bulk composition analyses reported on an "as received basis"

- $\mathrm{mg} / \mathrm{L}=\mathrm{ppm}$

- $g / L=\mathrm{ppb}$ 
Sample: Dowell flash Iank

Number: G) $(1428)$

Type: Scale

Location: Geothermal Test Facility, East Mesa (Imperial Valley)

Site Owner/Operator: DoE/Westec Services

\begin{tabular}{|c|c|c|c|}
\hline BULK COMPOSITION & $\begin{array}{l}\text { Tota } 1 \\
x \\
\end{array}$ & $\begin{array}{c}\text { Acld Extract } \\
\mathrm{mg} / \mathrm{L}\end{array}$ & $\begin{array}{l}\text { Neutral Extract } \\
\mathrm{mg} / \mathrm{L}\end{array}$ \\
\hline Aluminum (AI) & 0.29 & $<1$ & $<1$ \\
\hline Calctum (Ca) & 11.4 & 1,800 & 3.2 \\
\hline Iron (Fe) & 5.1 & $<0.2$ & $<0.2$ \\
\hline Magnesium $(\mathrm{Mg})$ & 0.13 & 4.4 & 0.08 \\
\hline Potassium (K) & 0.035 & 9.4 & 6.3 \\
\hline Sodium (Na) & 0.11 & 55 & 50 \\
\hline
\end{tabular}

$\begin{array}{llll}\text { Chloride (Cl) } & 0.080 & 57.0 & 59.0\end{array}$

D

Fluoride $(F)$

0.040

6.3

0.42

Silica $\left(\mathrm{SiO}_{2}\right)$

0.9

4.0

4.0

Sulf ate $\left(\mathrm{SO}_{4}\right)$

0.01

4.5

6.2

Sulfide (S)

$<0.01$

$<0.1$

$<0.1$

\begin{tabular}{l}
\hline ORGANICS \\
Priority Pollutants Detected \\
\hline NA \\
\hline Bioaccumulation Potential \\
\hline H g/L \\
\hline
\end{tabular}

Corrosivity

Moisture

TSS

Radium 226
IRACE ELEMENTS

Arsenic (As)

Barium (Ba)

Cadmium (Cd)

Chromium (Cr)

Lead (Pb)

Mercury ( $\mathrm{Hg})$

Selenium (Se)

silver (Ag)

\begin{tabular}{cc} 
Acid Extract & Neutral Extract \\
\cline { 1 - 2 } & $\frac{\mu g / L}{2} / L$ \\
36 & 33 \\
10,500 & 300 \\
$<5$ & $<5$ \\
$<20$ & $<20$ \\
$<20$ & $<20$ \\
$<1$ & $<1$ \\
$<20$ & $<20$ \\
$<20$ & $<20$ \\
&
\end{tabular}

$\begin{array}{lrr}\text { Ant imony (SB) } & 180 & 180 \\ \text { Beryllium (Be) } & <20 & <20 \\ \text { Boron (B) } & <200 & <200 \\ \text { Copper (Cu) } & 150 & 70 \\ \text { Lithium (Li) } & 220 & 140 \\ \text { Micke) (Ni) } & <200 & <200 \\ \text { Strontium (Sr) } & <500 & <500 \\ \text { Zinc (Zn) } & 70 & <20\end{array}$

180

20

70

140

$<20$ OTHER PARAMETERS

$8.8 \mathrm{pH}$

$\underline{61 x}$

NA

$3.0 \mathrm{pCt} / \mathrm{g}$ 
ample:

Brine Holding Pond

Number: $63(1430)$

Type: Sediment

Location: Geothermal Test Facility, East Mesa (Imperfal Valley)

Site Owner/Operator: DOE/Hestect Services

\begin{tabular}{|c|c|c|c|}
\hline BULK COMPOSITION & $\begin{array}{c}\text { Total } \\
x \\
\end{array}$ & $\begin{array}{c}\text { Acid Extract } \\
\mathrm{mg} / \mathrm{L} \\
\end{array}$ & $\begin{array}{c}\text { Neutral Extract } \\
\mathrm{mg} / \mathrm{l}\end{array}$ \\
\hline Aluminum (AI) & 0.22 & $<1$ & $<1$ \\
\hline Calctum (Ca) & 0.73 & 680 & 6.4 \\
\hline Iron (Fe) & 0.32 & 1.8 & $<0.2$ \\
\hline Magnesium $(\mathrm{Mg})$ & 0.15 & 7.5 & 0.48 \\
\hline Potasstum (K) & 0.094 & 17 & 11 \\
\hline Sodfum (Na) & 0.087 & 63 & 50 \\
\hline
\end{tabular}

TRACE ELEMENTS
Arsenic (As)
Barium (Ba)

Acid Extract

Barium (Ba)

Cadmi um (Cd)

Chromiun (Cr)

Lead (Pb)

Mercury ( $\mathrm{Hg})$

Selentum ( $\mathrm{Se}$ )

cid Extract

Neutral Extract

silver (Ag)

45

65

3,800

$<5$

$<20$

$<20$

$<1$

$<20$

$<20$

600

$g / L$

(ant

\begin{tabular}{|c|c|c|c|}
\hline Chlortde (Cl) & 0.090 & 49.0 & 58.0 \\
\hline Fluoride (F) & 0.010 & 1.8 & 0.74 \\
\hline Stlica $\left(\mathrm{SiO}_{2}\right)$ & 9.8 & 8 & 5 \\
\hline Sulf ate $\left(\mathrm{SO}_{4}\right)$ & 0.01 & 7.0 & 5.5 \\
\hline Sulfide (S) & $<0.0002$ & $<0.1$ & $<0.1$ \\
\hline
\end{tabular}

$\begin{array}{lrr}\text { Ant imony (Sb) } & <50 & <50 \\ \text { Berylllum (Be) } & <20 & <20 \\ \text { Boron (B) } & <2,000 & <200 \\ \text { Copper (Cu) } & <70 & <70 \\ \text { Lithium (Li) } & 170 & 130 \\ \text { Nickel (Ni) } & <200 & <200 \\ \text { Strontium (Sr) } & 8,300 & <500 \\ \text { Zinc (Zn) } & 110 & <20\end{array}$

ORGANICS

Priority Pollutants Detected

H g/L

NA

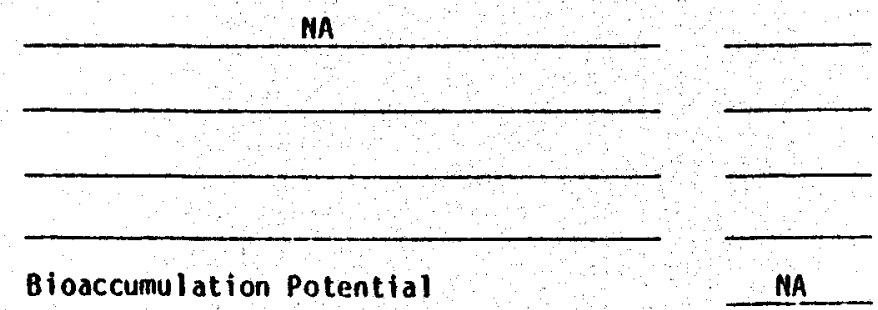

OTHER PARAMETERS

$\begin{array}{ll}\text { Corrosivity } & \frac{8.8 \mathrm{pH}}{} \\ \text { Moisture } & \frac{34 \times}{} \\ \text { TSS } & \frac{\mathrm{MA}}{} \\ \text { Radium 226 } & 3.8 \mathrm{pCl} / \mathrm{g}\end{array}$

Bioaccumulation Potential 
Sample: Mud Pit, Sperry Well

\section{Number: $\quad 66$ (1433) \\ Iype: Mud}

Location: East Mesa (Imperial Valley)

\begin{tabular}{|c|c|c|c|}
\hline BULK COMPOSITION & $\begin{array}{r}\text { Total } \\
x \\
\end{array}$ & $\begin{array}{c}\text { Acid Extract } \\
\mathrm{mg} / \mathrm{L}\end{array}$ & $\begin{array}{c}\text { Neutral Extract } \\
\mathrm{mg} / \mathrm{L}\end{array}$ \\
\hline Aluminum (AI) & 1.2 & 1.2 & 1.2 \\
\hline Calcium (Ca) & 1.65 & 1.100 & 28 \\
\hline Iron (Fe) & 0.66 & 5.8 & 0.2 \\
\hline Magnesium $(\mathrm{Mg})$ & 0.43 & 38 & 0.04 \\
\hline Potassium (K) & 0.36 & 24 & 18 \\
\hline Sodium (Na) & 0.24 & 115 & 105 \\
\hline
\end{tabular}

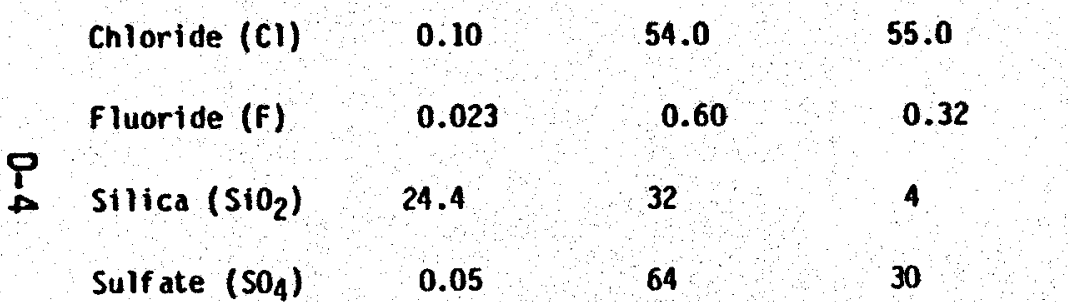

Sulfide (S)

$<0.1$

0.1

0.1

\begin{tabular}{l} 
ORGANICS \\
Priority Pollutants Detected \\
\hline Bioaccumulation Potential \\
\hline
\end{tabular}

Site Owner/Operator: Republic Geothermal

$\begin{array}{lcc}\text { IRACE ELEMENTS } & \begin{array}{c}\text { Acid Extract } \\ \mu g / L\end{array} & \begin{array}{c}\text { Neutral Extract } \\ \text { Ag/L }\end{array} \\ \text { Arsenic (As) } & <20 & <20 \\ \text { Barium (Ba) } & 1,400 & <300 \\ \text { Cadmium (Cd) } & <5 & <5 \\ \text { Chromium (Cr) } & <20 & <20 \\ \text { Lead (Pb) } & 30 & <20 \\ \text { Mercury (Hg) } & <1 & <1 \\ \text { Selentum (Se) } & <20 & <20 \\ \text { Silver (Ag) } & <20 & <20\end{array}$

$\begin{array}{lrr}\text { Ant imony (Sb) } & <50 & <50 \\ \text { Beryllium (Be) } & <20 & <20 \\ \text { Boron (B) } & <2,000 & <200 \\ \text { Copper (Cu) } & <70 & <70 \\ \text { Lithlum (Li) } & <50 & <50 \\ \text { Nickel (Ni) } & <200 & <200 \\ \text { Stront lua (Sr) } & 2,200 & <500 \\ \text { Zinc (Zn) } & 150 & <20\end{array}$

OTHER PARAMETERS

$\begin{array}{ll}\text { Corrosivity } & \frac{12.0 \mathrm{pH}}{} \\ \text { Molsture } & 60 \times \\ \text { TSS } & \mathrm{NA} \\ \text { Radium 226 } & 1.0 \mathrm{pCl} / \mathrm{g}\end{array}$




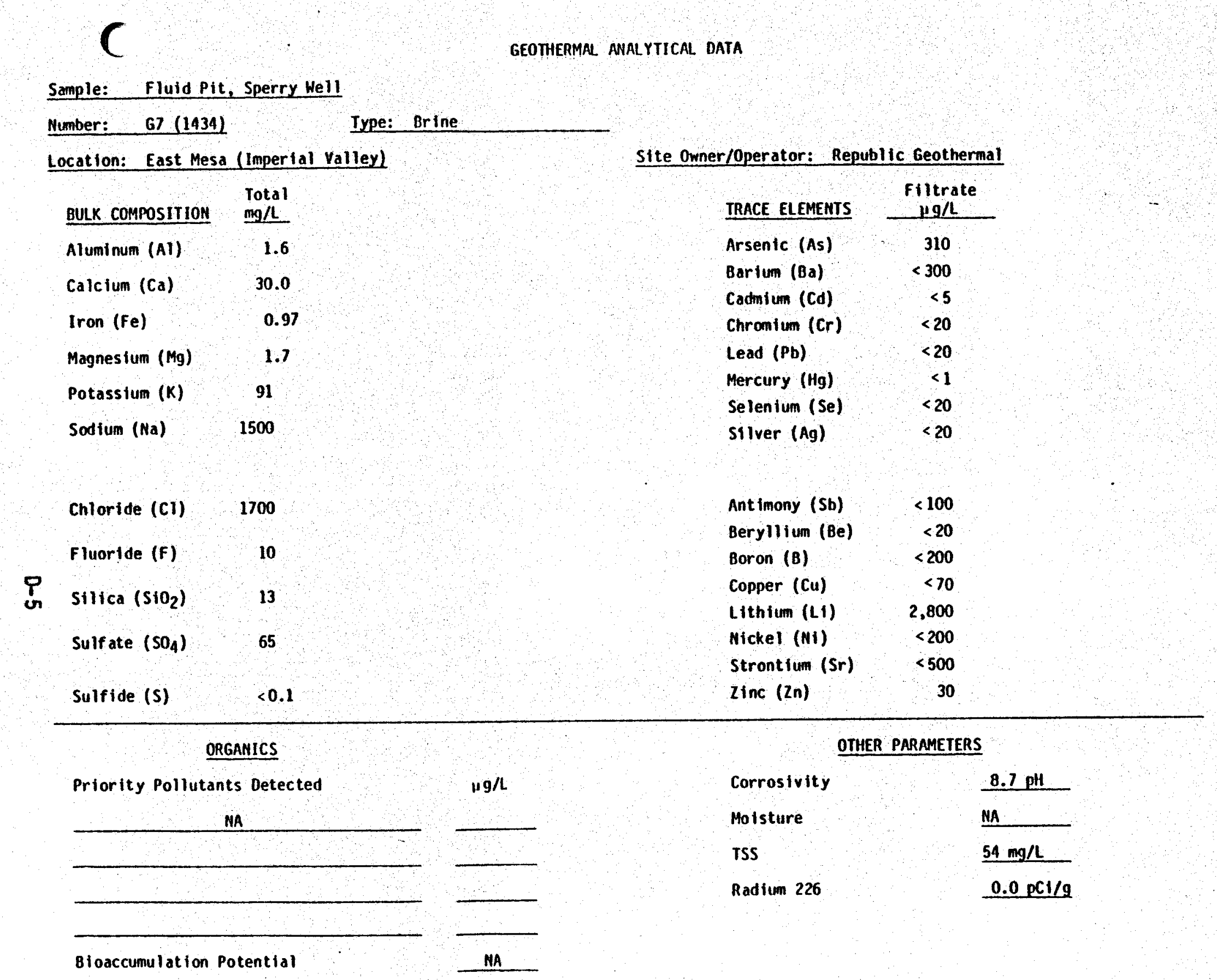


Sample:

Clarif ier Reactor Sludge Underflow

Number: 68 (1435) Iype: Sludge

Location: Geothermal Loop Experimental facility, Near Niland (Imperial Valley) S Site Owner/0perator: DoE/Magma Power

\begin{tabular}{lccc} 
BuLK Composition & Total & $\frac{\text { Acid Extract }}{\mathrm{mg} / \mathrm{L}}$ & $\begin{array}{c}\text { Neutral Extract } \\
\mathrm{mg} / \mathrm{L}\end{array}$ \\
\hline Aluminum (AI) & $<0.01$ & $<1$ & $<1$ \\
Calcium (Ca) & 1.5 & 800 & 840 \\
Iron (fe) & 2.45 & 1.0 & $<0.2$ \\
Magnesium (Mg) & 0.020 & 3.5 & 3.7 \\
Potassium (K) & 1.1 & 400 & 400 \\
Sodium (Na) & 4.3 & 1,900 & 1,900
\end{tabular}

\begin{tabular}{|c|c|c|c|}
\hline Chloride (Cl) & 9.3 & 5,000 & 5,370 \\
\hline Fluoride $(F)$ & 0.34 & 1.7 & 1.8 \\
\hline silica $\left(\mathrm{SiO}_{2}\right)$ & 12.4 & 4 & 2 \\
\hline Sulf ate $\left(\mathrm{SO}_{4}\right)$ & 0.007 & 1.0 & 6.5 \\
\hline Sulfide (S) & $<0.01$ & $<0.1$ & $<0.1$ \\
\hline
\end{tabular}

\begin{tabular}{|c|c|c|}
\hline TRACE ELEMENTS & $\begin{array}{c}\text { Acid Extract } \\
\mathrm{Ug} / \mathrm{L}\end{array}$ & $\begin{array}{l}\text { Meutral Extract } \\
\quad 19 / 2\end{array}$ \\
\hline Arsenic (As) & 230 & 230 \\
\hline Barium (Ba) & 5,000 & 5,400 \\
\hline Cadmium (Cd) & 60 & 60 \\
\hline Chromium (Cr) & $<20$ & $<20$ \\
\hline Lead $(P b)$ & 200 & $<20$ \\
\hline Mercury (Hg) & $<1$ & $<1$ \\
\hline Selenium (Se) & 180 & 220 \\
\hline Silver (Ag) & $<20$ & $<20$ \\
\hline Ant imony (Sb) & $<50$ & $<50$ \\
\hline Beryllium (Be) & $<20$ & $<20$ \\
\hline Boron (B) & 12,000 & 13,000 \\
\hline Copper (Cu) & 150 & $<70$ \\
\hline Lithfum (LI) & 5,800 & 7,900 \\
\hline Nickel (Ni) & 500 & $<200$ \\
\hline Strontium (Sr) & 12,000 & 15,000 \\
\hline $\operatorname{Zinc}(Z n)$ & 6,400 & 4,000 \\
\hline
\end{tabular}

\begin{tabular}{c} 
ORGANICS \\
Priority Pollutants Detected \\
\hline MA \\
\hline Bioaccumulation Potential \\
\hline$N 9 / L$ \\
\hline
\end{tabular}

OTHER PARAMETERS

$\begin{array}{ll}\text { Corrosivity } & 6.1 \mathrm{pH} \\ \text { Moisture } & 46 \times \\ \text { TSS } & \frac{\mathrm{NA}}{7 \mathrm{pCl} / 9} \\ \text { Radium 226 } & \end{array}$




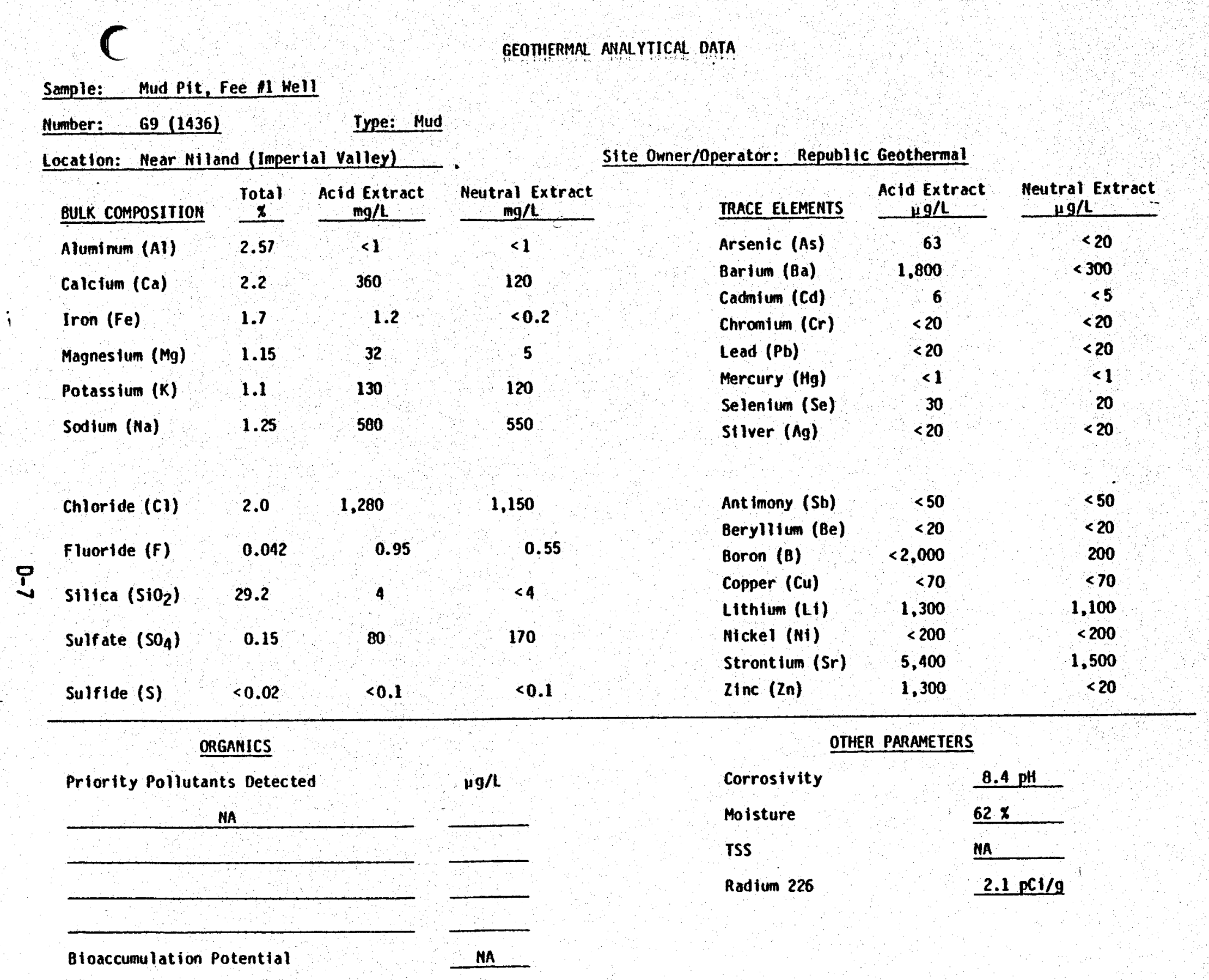




\section{Sample:} North Brine Pit, fee 11 Well

Number: $610(1676) \quad$ Iype: Orine

Location: Near Niland (Imperial Valley)

\begin{tabular}{lr}
\hline BuLK COMPOSITION & $\begin{array}{r}\text { Total } \\
\mathrm{mg} / \mathrm{L}\end{array}$ \\
\hline Aluminum (Al) & $<1$ \\
\hline Calcium (Ca) & 51,000 \\
\hline Iron (Fe) & 3,200 \\
Magnesium (Mg) & 313 \\
Potassium (K) & 38,000 \\
\hline Sodium (Na) & 55,000
\end{tabular}

\begin{tabular}{ccc} 
Chloride (Cl) & 295,000 \\
\hline Fluoride (F) & 19 \\
\hline o Sillica $\left(\mathrm{SiO}_{2}\right)$ & 300 \\
Sulfate $\left(\mathrm{SO}_{4}\right)$ & $<0.01$ \\
Sulfide (S) & $<0.1$
\end{tabular}

ORGANICS

Priority Pollutants Detected

MA

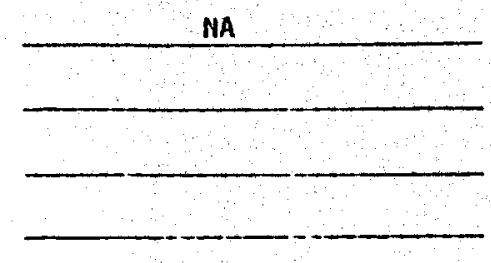

Bioaccumulation Potential

Site Owner/0perator: Republic Geothermal

\begin{tabular}{lc} 
TRACE ELEMENTS & $\begin{array}{c}\text { Filtrate } \\
\mu g / \mathrm{L}\end{array}$ \\
\hline Arsenic (As) & $<250$ \\
Barlum (Ba) & 363,000 \\
Cadnilum (Cd) & 70 \\
Chromium (Cr) & 980 \\
Lead (Pb) & 6,300 \\
Mercury (Hg) & Int \\
Selenium (Se) & $<500$ \\
Silver (Ag) & $<20$
\end{tabular}

$\begin{array}{lr}\text { Ant imony (SB) } & <200 \\ \text { Beryllium (Be) } & <20 \\ \text { Boron (B) } & 660,000 \\ \text { Copper (Cu) } & 7,400 \\ \text { Lithium (Li) } & 509,000 \\ \text { Nickel (Ni) } & 300 \\ \text { Strontium (Sr) } & 1,290,000 \\ \text { Zinc (Zn) } & 1,130,000\end{array}$

OTHER PARAMETERS

\begin{tabular}{|c|c|}
\hline Corrosivity & $1.6 \mathrm{pH}$ \\
\hline Moisture & MA \\
\hline ISS & $5600 \mathrm{mg} / \mathrm{L}$ \\
\hline Radium 226 & $0.4 \mathrm{pCl} / \mathrm{g}$ \\
\hline
\end{tabular}


Sample:

Class II-2 Landf iII

Number: 612 (1437)

Iype: Mixed Solids

Location: Brawley (Imperial Valley)

\begin{tabular}{|c|c|c|c|}
\hline BULK COMPOSITION & $\begin{array}{l}\text { Total } \\
x \\
\end{array}$ & $\begin{array}{c}\text { Acld Extract } \\
\mathrm{mg} / \mathrm{L}\end{array}$ & $\begin{array}{c}\text { Neutral Extract } \\
\mathrm{mg} / \mathrm{L}\end{array}$ \\
\hline Alumi num (AI) & 2.3 & $<1$ & 190 \\
\hline Calctum (Ca) & 1.60 & 680 & 33 \\
\hline Iron (Fe) & 1.2 & 0.8 & 76 \\
\hline Magnes lum (Mg) & 1.72 & 20 & 52 \\
\hline Potassium (K) & 0.69 & 48 & 85 \\
\hline Sodium (Na) & 0.50 & 235 & 230 \\
\hline Chloride (Cl) & 0.40 & 215 & 227 \\
\hline fluoride $(F)$ & 0.033 & 0.29 & 0.56 \\
\hline Sillica $\left(\mathrm{SiO}_{2}\right)$ & 24.2 & 2 & 160 \\
\hline Sulfate $\left(\mathrm{SO}_{4}\right)$ & 0.06 & 10 & 85 \\
\hline Sulfide $(s)$ & $<0.01$ & $<0.1$ & $<0.1$ \\
\hline
\end{tabular}

Site Owner/Operator: Imperial County Dept. of Public Works

ORGAMICS

Priority Pollutants Detected

Acid Extract

phenol.

$\mu \mathrm{g} / \mathrm{t}$

Neutral Extract 4,6-dinitro-o-creosol

4

phenol
anthracene/phenanthrene $\frac{2}{6}$

Bioaccumulation Potential

Acid extract

$\begin{array}{ll}\text { Neutral extract } & \text { negative } \\ \text { positive }\end{array}$

\begin{tabular}{|c|c|}
\hline $\begin{array}{c}\text { Acid Extract } \\
\mu \mathrm{g} / \mathrm{L}\end{array}$ & $\begin{array}{l}\text { Neutral Extract } \\
\text { y } g / L\end{array}$ \\
\hline 100 & $<250$ \\
\hline 1,000 & 1,400 \\
\hline$<5$ & $<5$ \\
\hline 23 & 420 \\
\hline$<20$ & 200 \\
\hline$<1$ & Int \\
\hline$<20$ & $<50$ \\
\hline$<20$ & $<20$ \\
\hline
\end{tabular}

Ant imony (Sb) $<50 \quad<100$

Beryllium (Be) $\quad<20 \quad<20$

Boron (B) $\quad<200 \quad 340$

Copper (Cu) $\quad<70 \quad 230$

Lithium (L1) $\quad 130 \quad 340$

Nickel (NI) $\quad<200 \quad<200$

Stront Ium (Sr) $\quad 2,400 \quad<100$

Zinc $(2 n) \quad 250 \quad 1,400$
OTHER PARAMETERS

\begin{tabular}{|c|c|}
\hline Corrosivity & $10 \mathrm{pH}$ \\
\hline Moisture & $51 x$ \\
\hline TSS & NA \\
\hline Radium 226 & $1.15 \mathrm{pCl} / \mathrm{g}$ \\
\hline
\end{tabular}


Sample: East Baker Tank, Courier 11 Well

Number: $614(1439) \quad$ Iype: Brine
Location: Westmorland (Imperial Valley)

Location: Hestmorland (Imperial Valley)

\begin{tabular}{lr} 
BuLK COMPOSITION & \multicolumn{1}{c}{$\begin{array}{c}\text { Total } \\
\mathrm{mg} / \mathrm{L}\end{array}$} \\
\hline Aluminum (Al) & 1.2 \\
Calcium (Ca) & 14,800 \\
Iron (Fe) & 2,100 \\
Magnesium (Mg) & 440 \\
Potassium (K) & 10,000 \\
Sodium (Na) & 60,000
\end{tabular}

\begin{tabular}{ll} 
Chloride (CI) & 158,700 \\
Fluoride (F) & 10 \\
\hline $0 \quad$ Silica $\left(\mathrm{SiO}_{2}\right)$ & 18 \\
Sulfate $\left(\mathrm{SO}_{4}\right)$ & $<1$
\end{tabular}

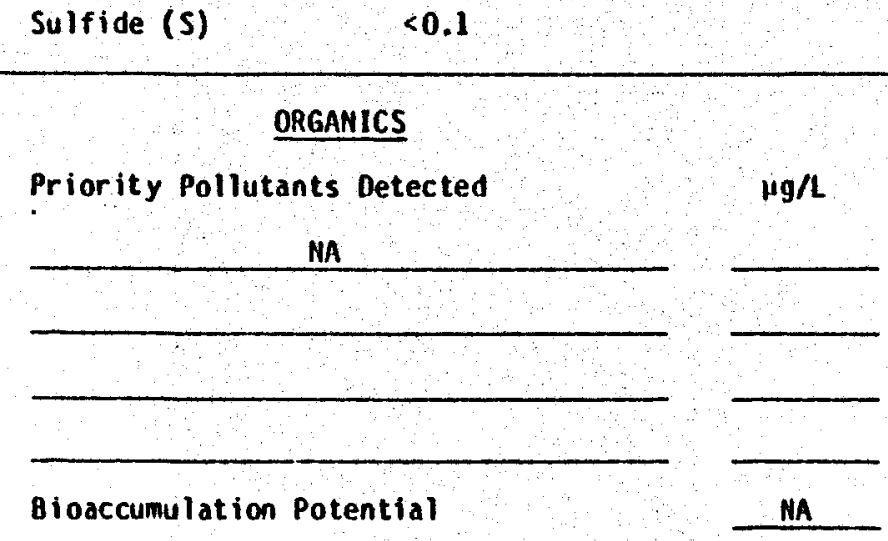

Site Owner/0perator: MAPCO

TRACE ELEMENTS

Arsenic (As)

Bariun (Ba)

Cadmium (Cd)

Chromium (Cr)

Lead (Pb)

Mercury ( $\mathrm{Hg})$

Selenium (Se)

Silver (Ag)

Ant imony (Sb)

Berylllum (Be)

Boron (B)

Copper (Cu)

Lithlum (Li)

Nickel (Ni)

Strontium (Sr)

Zinc (Zn)
Filtrate $19 / 2$

14,000

22,000

4,000

$<60$

83,000

$<1$

5,100

$<20$

$<1,000$

$<20$

230,000

$<100$

240

$<200$

$1,400,000$

$6,000,000$ 


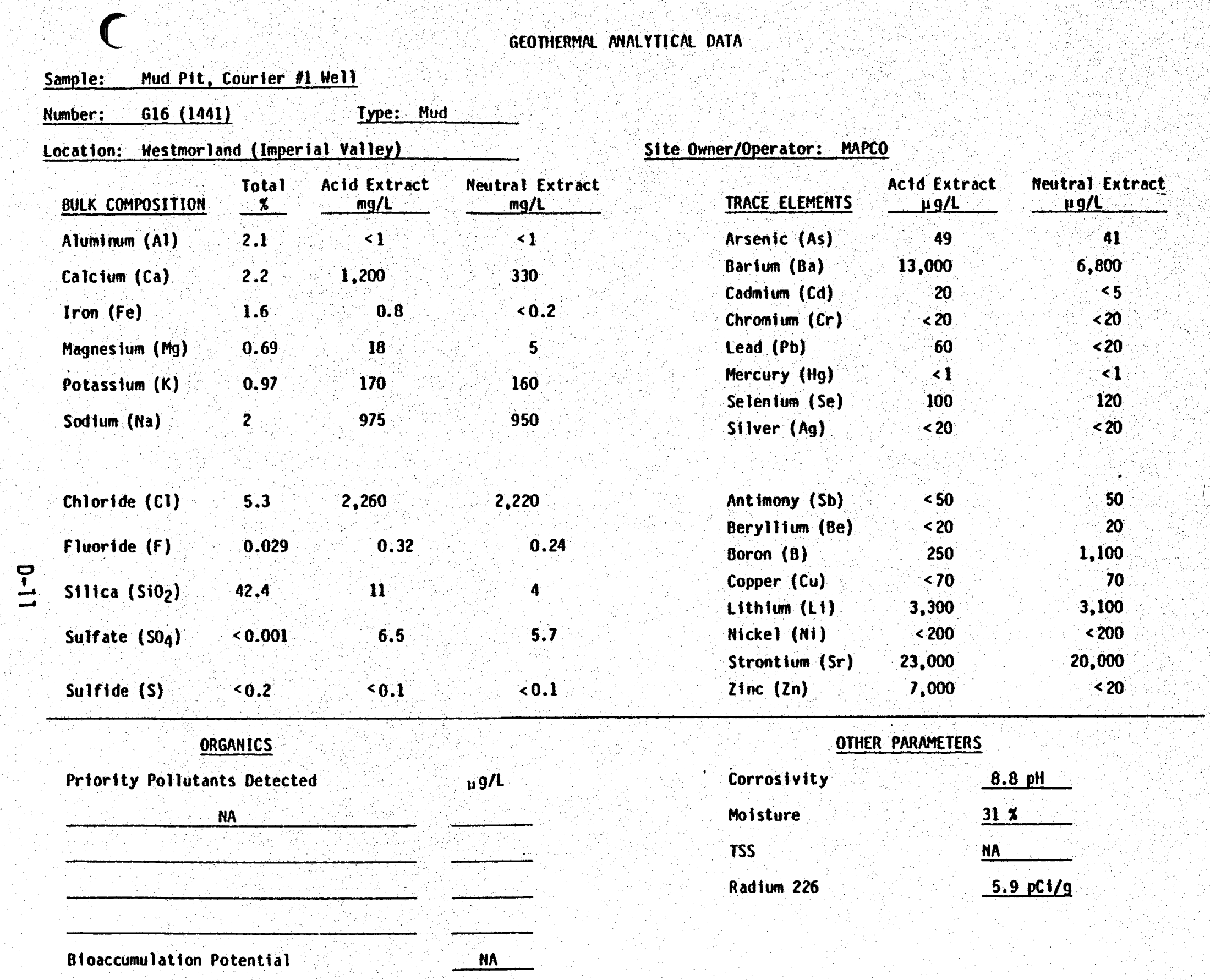


Sample: Iron Sludge from Centrifuge

Number: G19-1 (1576) Iype: Sludge

Location: Unit 12 (The Geysers)

\begin{tabular}{|c|c|c|c|}
\hline BULK COMPOSITION & $\begin{array}{r}\text { Total } \\
x\end{array}$ & $\begin{array}{c}\text { Acld Extract } \\
\mathrm{mg} / \mathrm{L}\end{array}$ & $\begin{array}{c}\text { Meutral Extract } \\
\mathrm{mg} / \mathrm{L}\end{array}$ \\
\hline Alumimum (Al) & 0.01 & $<1$ & $<1$ \\
\hline Calcium (Ca) & $<0.005$ & 2.9 & 2.1 \\
\hline Iron (fe) & 9.45 & 0.8 & $<0.2$ \\
\hline Magnesium (Mg) & $<0.005$ & 0.28 & 0.22 \\
\hline Potassium (K) & 0.002 & 0.28 & 0.23 \\
\hline Sodium (Na) & 0.041 & 17 & 16 \\
\hline Chloride (C1) & 0.005 & $<1$ & 1 \\
\hline Fluoride (F) & 0.003 & 0.11 & 0.11 \\
\hline sillica $\left(\mathrm{SiO}_{2}\right)$ & 0.004 & $<4$ & $<4$ \\
\hline Sulf ate $\left(\mathrm{SO}_{4}\right)$ & 0.22 & $<1$ & 55 \\
\hline Sulfide (S) & $<0.2$ & $<0.1$ & $<0.1$ \\
\hline
\end{tabular}

ORGAMICS

Priority Pollutants Detected

NA

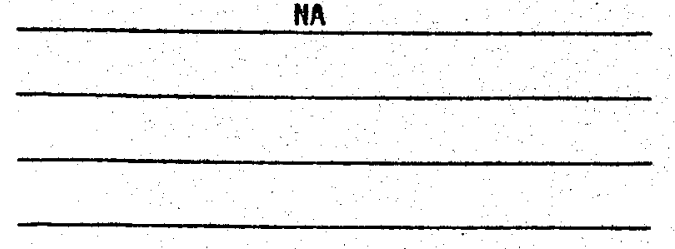

Bloaccumulation Potential

\begin{abstract}
$\mu g / L$
\end{abstract}

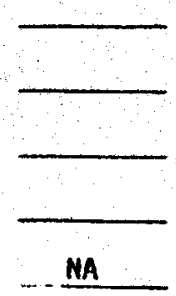

Site Owner/0perator: PGBE

IRACE ELEMENTS

$\underset{\mu g / L}{A}$

Meutral Extract

Arsenic (As)

$<20$

Hg/L

Barium (Ba)

Cadmium (Cd)

Chromium (Cr)

Lead (Pb)

Mercury (Hg)

Selentum (Se)

Silver (Ag)

$<300$

$<20$

$<300$

$<5$

$<20$

$<20$

$<1$

$<20$

$<20$

$<5$

$<20$

$<20$

$<1$

$<20$

$<20$

Ant imony (Sb) $<50 \quad<50$

Beryllium (Be) $<20 \quad<20$

$\begin{array}{lll}\text { Boron (B) } \quad 7,600 & 520\end{array}$

Copper (Cu) $\quad<70 \quad<50$

Lithium (LI) $\quad<50 \quad<50$

Nickel (Ni) $\quad 300 \quad<200$

Strontium (Sr) $<500 \quad<500$

Zinc $(Z n)$

200

50

OTHER PARAMETERS

Corrosivity

Moisture

TSS

Radium 226
$6.2 \mathrm{pH}$

$\underline{80 x}$

MA

$0 \mathrm{pCl} / \mathrm{g}$ 
Sample: Cooling Tower Sediment

Number: G20-1 (1577A) Type: Sediment

Location: Unit 9 (The Geysers)

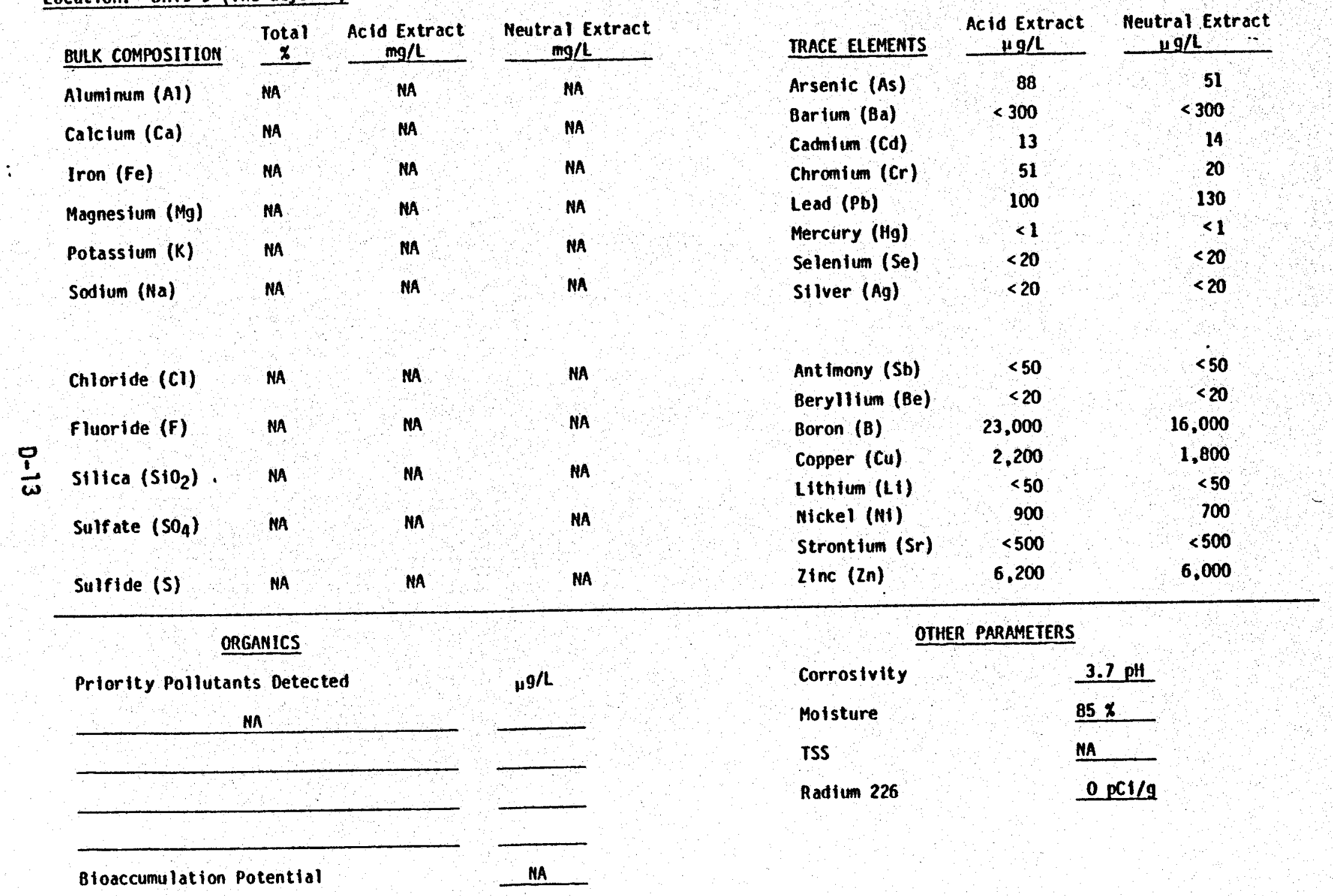


Sample: Cooling Tower Sediment

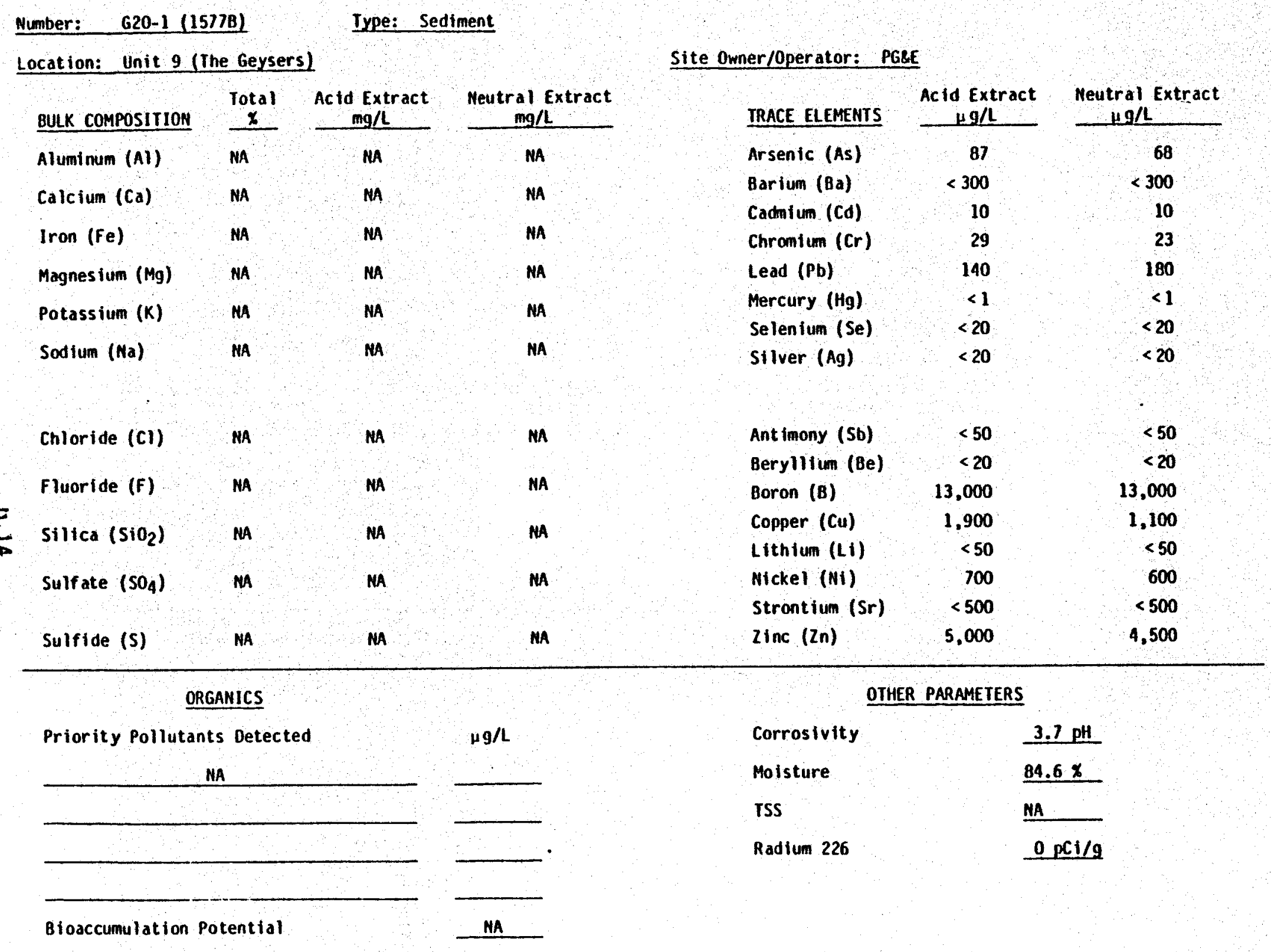


ample:

Iron Sludge from Centrifuge

Number: 622-1 (1579) Type: Sludge

Location: Unit 5 \& 6 (The Geysers)

\begin{tabular}{|c|c|c|c|}
\hline BULK COMPOSITION & $\begin{array}{l}\text { Total } \\
\% \\
\end{array}$ & $\begin{array}{c}\text { Acid Extract } \\
\mathrm{mg} / \mathrm{L}\end{array}$ & $\begin{array}{c}\text { Neutral Extract } \\
\mathrm{mg} / \mathrm{L}\end{array}$ \\
\hline Aluminum (AI) & 0.01 & $<1$ & $<1$ \\
\hline Calcfum (Ca) & 0.005 & 2.4 & 2 \\
\hline Iron (Fe) & 7.7 & $<0.2$ & $<0.2$ \\
\hline Magneslum (Mg) & $<0.005$ & 0.20 & 0.16 \\
\hline Potassium $(K)$ & 0.004 & 0.18 & 0.15 \\
\hline Sodium (Na) & 0.055 & 24 & 24 \\
\hline Chloride (Cl) & $<0.005$ & $<1$ & $<1$ \\
\hline Fluoride $(F)$ & 0.001 & 0.12 & 0.14 \\
\hline Silica $\left(\mathrm{SiO}_{2}\right)$ & 0.04 & $<4$ & $<4$ \\
\hline Sulfate $\left(\mathrm{SO}_{4}\right)$ & 0.29 & 9.5 & 85 \\
\hline Sulfide (S) & $<0.2$ & $<0.1$ & $<0.1$ \\
\hline
\end{tabular}

ORGANICS

Priority Pollutants Detected

Acld Extract phenol

benzo (k) fluoranthene

Neutral Extract

Bioaccumulation Potential
Acid Extract

Neutral Extract

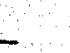

\section{GEOTHERMAL ANALYTICAL DATA}


Sample:

Cooling Tower Sediment

Number:

$623-1$ (1580)

Iype: Sediment

Location: Unit $7 \& 8$ (The Geysers)

\begin{tabular}{|c|c|c|c|}
\hline BULK COMPOSITION & $\begin{array}{r}\text { Total } \\
\times \\
\end{array}$ & $\begin{array}{c}\text { Acid Extract } \\
\mathrm{mg} / \mathrm{L} \\
\end{array}$ & $\begin{array}{c}\text { Neutral Extract } \\
\mathrm{mg} / \mathrm{L}\end{array}$ \\
\hline Aluminum (AI) & 0.52 & 1 & $<1$ \\
\hline Calcium (Ca) & 0.02 & 1.7 & 1.7 \\
\hline Iron (Fe) & 11.3 & 44 & 50 \\
\hline Magnesium $(\mathrm{Mg})$ & 0.22 & 0.36 & 0.30 \\
\hline Potassium (K) & 0.12 & 0.23 & 0.23 \\
\hline Sodium (Na) & 0.016 & 0.9 & 0.9 \\
\hline Chloride (Cl) & $<0.005$ & 2 & 2 \\
\hline Fluoride $(F)$ & 0.005 & 0.16 & 0.15 \\
\hline Sillca $\left(\mathrm{SiO}_{2}\right)$ & 3.6 & $<4$ & $<4$ \\
\hline Sulf ate $\left(\mathrm{SO}_{4}\right)$ & 0.65 & 300 & 260 \\
\hline Sulfide (s) & $<0.08$ & $<0.1$ & $<0.1$ \\
\hline
\end{tabular}

Site Owner/Operator: PG\&E

\begin{tabular}{|c|c|c|}
\hline IRACE ELEMENTS & $\begin{array}{c}\text { Acid Extract } \\
\mu \mathrm{g} / \mathrm{L}\end{array}$ & $\begin{array}{l}\text { Neutral Extract } \\
\quad 19 / \mathrm{L}\end{array}$ \\
\hline Arsenic (As) & 110 & 150 \\
\hline Barium (Ba) & $<300$ & $<300$ \\
\hline Cadmium (Cd) & $<60$ & $<60$ \\
\hline Chromium (Cr) & $<20$ & $<20$ \\
\hline Lead $(P b)$ & 70 & 50 \\
\hline Mercury $(\mathrm{Hg})$ & $<1$ & $<1$ \\
\hline Selenlum (Se) & $<20$ & $<20$ \\
\hline Silver (Ag) & $<20$ & $<20$ \\
\hline Ant imony (Sb) & $<50$ & $<50$ \\
\hline Beryllium (Be) & $<20$ & $<20$ \\
\hline Boron (B) & 7,700 & 880 \\
\hline Copper (Cu) & 60,000 & 33,000 \\
\hline Lithium (LI) & $<50$ & $<50$ \\
\hline Nickel (Ni) & $<500$ & $<500$ \\
\hline Strontium (Sr) & $<500$ & $<500$ \\
\hline $2 \operatorname{lnc}(2 n)$ & 7,500 & 6,000 \\
\hline
\end{tabular}

\section{ORGANICS}

Priority Pollutants Detected

MA

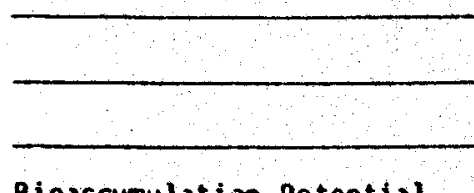

$\mu \mathrm{g} / \mathrm{L}$
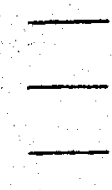

\section{OTHER PARAMETERS}

$\begin{array}{ll}\text { Corrosivity } & \frac{5.1 \mathrm{pH}}{\text { Moisture }} \\ \text { rSS } & 71 \mathrm{NA} \\ \text { Radium 226 } & \frac{\mathrm{HA}}{\mathrm{pCl} / \mathrm{g}}\end{array}$

Bioaccumulatiom Potential 
Sample: Abated Hell Sump, Beigel fl Hell

Mumber: 624-1 (1581R) Iype: Mud

Location: Near Unit 18 (The Geysers)

\section{BULK COMPOSITION \\ Aluminum (AI)}

Calcium (Ca)

Iron (Fe)

Magnes lum (Mg)

Potassium (K)

Sodium (Na)

$\frac{\text { Total AcId Extract }}{1.58} \frac{\mathrm{mg} / \mathrm{L}}{<1}$

Neutral Extract

$\frac{m g / L}{<1}$

34

$<0.2$

3.03

32

9.6

6.3

$<0.04$

2.5

24

48

\begin{tabular}{lllll} 
Chloride $(\mathrm{Cl})$ & 0.014 & 2 & $<1$ \\
\hline I fluoride (F) & 0.024 & 0.34 & 0.28 \\
\hline Stlica $\left(\mathrm{SiO}_{2}\right)$ & 19.4 & $<4$ & 16 \\
\hline Sulfate $\left(\mathrm{SO}_{4}\right)$ & 0.02 & 32 & 62 \\
\hline Sulfide $(\mathrm{S})$ & $<0.02$ & $<0.1$ & $<0.1$ \\
\hline
\end{tabular}

\section{ORGANICS}

Priority Pollutants Detected

Acid Extract 2-nitrophenol

phenol

Neutral Extract phenol

Bloaccumulation Potential

Acld Extract

Neutral Extract

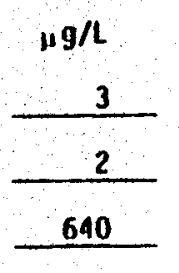

negat ive

negative
Site Owner/Operator: Union oil of California

\begin{tabular}{|c|c|c|}
\hline TRACE ELEMENTS & $\begin{array}{c}\text { Acid Extract } \\
\mu g / L\end{array}$ & $\begin{array}{l}\text { Neutral Extract } \\
\quad \mu g / L\end{array}$ \\
\hline Arsenic (As) & $<20$ & 32 \\
\hline Barium (Ba) & $<300$ & $<300$ \\
\hline Cadmium (Cd) & $<5$ & $<5$ \\
\hline Chromiun (Cr) & $<20$ & $<20$ \\
\hline Lead $(\mathrm{Pb})$ & $<20$ & $<20$ \\
\hline Mercury $(\mathrm{Hg})$ & $<1$ & $<1$ \\
\hline Selenium (Se) & $<20$ & $<20$ \\
\hline Silver (Ag) & $<20$ & $<20$ \\
\hline
\end{tabular}

$\begin{array}{lrr}\text { Ant imony (Sb) } & <50 & <50 \\ \text { Beryllium (Be) } & <20 & <20 \\ \text { Boron (B) } & 870 & 15,000 \\ \text { Copper (Cu) } & <70 & <70 \\ \text { Lithium (Li) } & <50 & <50 \\ \text { Nickel (Ni) } & 300 & 500 \\ \text { Strontium (Sr) } & 600 & <500 \\ \text { Zinc (Zn) } & 300 & <20\end{array}$

$\operatorname{linc}(2 n)$

OTHER PARAMETERS

$\begin{array}{ll}\text { Corrosivity } & \frac{10 \mathrm{pH}}{\text { Moisture }} \\ \text { TSS } & \frac{53 \times}{N A} \\ \text { Radium } 226 & 0.5 \mathrm{pCi} / \mathrm{g}\end{array}$


Sample:

Sedimentation Pond

Number: G26-1 (1585R)

\section{Type: Sediment}

Location: Unit 12 (The Geysers)

\begin{tabular}{|c|c|c|c|}
\hline BULK COMPOSITION & $\begin{array}{c}\text { Total } \\
\times \\
\end{array}$ & $\begin{array}{c}\text { Acid Extract } \\
\mathrm{mg} / \mathrm{L}\end{array}$ & $\begin{array}{c}\text { Neutral Extract } \\
\mathrm{mg} / \mathrm{L}\end{array}$ \\
\hline Alumi num (AI) & 0.01 & $<1$ & $<1$ \\
\hline Calcium (Ca) & $<0.005$ & 4.8 & 2.1 \\
\hline Iron (Fe) & 6.4 & 630 & 730 \\
\hline Magnesium (Mg) & $<0.005$ & 1.2 & 1.5 \\
\hline Potassiun (K) & 0.002 & 0.60 & 0.71 \\
\hline Sodtum (Na) & 0.051 & 60 & 71 \\
\hline
\end{tabular}

\begin{tabular}{|c|c|c|c|}
\hline Chloride (Cl) & 0.010 & 1 & 2 \\
\hline Fluoride (F) & 0.001 & 0.12 & 0.07 \\
\hline Sillica $\left(\mathrm{SiO}_{2}\right)$ & 0.04 & 5 & 4 \\
\hline Sulf ate $\left(\mathrm{SO}_{4}\right)$ & 1.1 & 1,400 & 1,900 \\
\hline Sulfide (S) & $<0.02$ & $<0.1$ & $<0.1$ \\
\hline
\end{tabular}

Ant imony (Sb)

Beryllium (Be)

Boron (B)

Copper (Cu)

Lithium (LI)

Nickel (Ni)

Stront lum (Sr)

Zinc (Zn)

\section{: Unton oil of California}

TRACE ELEMENTS

Acld Extract Neutral Extract

$\mu \mathrm{g} / \mathrm{L}-\mu \mathrm{g} / \mathrm{L}$

Barium (Ba)

Cadmium (Cd)

Chromium (Cr)

Mercury $(\mathrm{Hg})$

Selentum (Se)

$20 \quad 34$

$<300 \quad<300$

$\begin{array}{rr}8 & 7 \\ 53 & <20\end{array}$

$<20 \quad<20$

$<1 \quad<1$

$30 \quad 40$

$<20 \quad<20$

\begin{tabular}{c} 
Priority Pollutants Detected \\
\hline ORGANICS \\
\hline Bloaccumulation Potential \\
\hline Mg/L \\
\hline
\end{tabular}

\section{OTHER PARAMETERS}

$\begin{array}{ll}\text { Corrosivity } & \frac{4.2 \mathrm{pH}}{88 \times} \\ \text { Moisture } & \frac{88 \times}{\mathrm{NA}} \\ \text { TSS } & 0 \mathrm{pCl} / \mathrm{g} \\ \text { Radium } 226 & \end{array}$

Bloaccumulation Potential 
Sample: Sump in Mud Drilling Phase, Aminoll of Hell

Number: G27-1 (1587) Iype: Mud

Location: Near Unit 13 (The Geysers)

\begin{tabular}{|c|c|c|c|}
\hline BULK COMPOSITION & $\begin{array}{c}\text { Total } \\
x \\
\end{array}$ & $\begin{array}{c}\text { Acid Extract } \\
\mathrm{mg} / \mathrm{L}\end{array}$ & $\begin{array}{l}\text { Neutral Extract } \\
\text { mg } / \mathrm{L}\end{array}$ \\
\hline Alumi num (AI) & 2.45 & $<1$ & $<1$ \\
\hline Calclum (Ca) & 0.93 & 690 & 0.81 \\
\hline Iron (Fe) & 3.9 & 14 & 0.8 \\
\hline Magnesium (Mg) & 1.78 & 6 & 0.40 \\
\hline Potassium (K) & 0.51 & 2.5 & 0.83 \\
\hline Sodium (Na) & 0.090 & 28 & 25 \\
\hline Chloride (Cl) & 0.005 & 3 & 1 \\
\hline Fluoride (F) & 0.018 & 0.13 & 0,14 \\
\hline Silica $\left(\mathrm{StO}_{2}\right)$ & 45.6 & 5 & 4 \\
\hline Sulf ate $\left(\mathrm{SO}_{4}\right)$ & 0.001 & $<1$ & 14 \\
\hline Sulfide (S) & $<0.0002$ & $<0.1$ & $<0.1$ \\
\hline
\end{tabular}

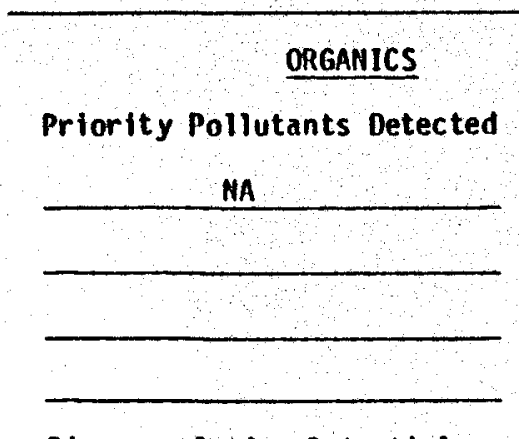

Bloaccumulation Potential
Site owner/operator: AnInoil USA

\begin{tabular}{|c|c|c|}
\hline TRACE ELEMENTS & $\begin{array}{c}\text { Acid Extract } \\
\mu \mathrm{g} / \mathrm{L}\end{array}$ & $\begin{array}{l}\text { Neutral Extract } \\
\quad \mu g / L\end{array}$ \\
\hline Arsenic (As) & $<20$ & 20 \\
\hline Barium (Ba) & 1,400 & $<300$ \\
\hline Cadmitum (Cd) & $<5$ & $<5$ \\
\hline Chromiun (Cr) & 70 & $<20$ \\
\hline Lead $(\mathrm{Pb})$ & 20 & $<20$ \\
\hline Mercury $(\mathrm{Hg})$ & $<1$ & $<1$ \\
\hline Selentum (Se) & $<20$ & $<20$ \\
\hline Silver (Ag) & $<20$ & $<20$ \\
\hline Ant imony (Sb) & $<50$ & $<50$ \\
\hline Beryllium (Be) & $<20$ & $<20$ \\
\hline Boron (B) & $<200$ & $<200$ \\
\hline Copper (Cu) & $<70$ & $<70$ \\
\hline Lithium (LI) & $<50$ & $<50$ \\
\hline Nickel (Ni) & $<500$ & $<500$ \\
\hline Strontium $(S r)$ & 3,500 & $<500$ \\
\hline$Z$ Inc $(2 n)$ & 80 & $<20$ \\
\hline
\end{tabular}

\section{OTHER PARAMETERS}

$\begin{array}{ll}\text { Corrosivity } & \frac{9.6 \mathrm{pH}}{23 \times} \\ \text { Molsture } & 23 \times \\ \text { TSS } & \mathrm{NA} \\ \text { Radium } 226 & 0.4 \mathrm{pCI} / \mathrm{g}\end{array}$




\section{Sample:}

Sump, Steamboat $\| 1$ Well

Number: G30 (1668) Iype: Mud

Location: Steamboat (Nevada)

\begin{tabular}{|c|c|c|c|}
\hline BULK COMPOSIIION & $\begin{array}{l}\text { Total } \\
x \\
\end{array}$ & $\begin{array}{c}\text { Acld Extract } \\
\mathrm{mg} / \mathrm{L}\end{array}$ & $\begin{array}{l}\text { Neutral Extract } \\
\mathrm{mg} / \mathrm{L}\end{array}$ \\
\hline Aluminum (AI) & 1.63 & $<1$ & $<1$ \\
\hline Calcium (Ca) & 1.8 & 700 & 8.1 \\
\hline Iron (Fe) & 1.85 & 1.6 & $<0.2$ \\
\hline Magneslum (Mg) & 0.67 & 15 & 0.08 \\
\hline Potassium $(K)$ & 0.46 & 21 & 12 \\
\hline Sodium (Na) & 0.19 & 53 & 48 \\
\hline
\end{tabular}

\begin{tabular}{|c|c|c|c|}
\hline Chloride (CI) & 0.039 & 23 & 22 \\
\hline Fluoride (F) & 0.015 & 0.54 & 0.46 \\
\hline Silica $\left(\mathrm{SiO}_{2}\right)$ & 21.6 & 14 & 13 \\
\hline Sulfate $\left(\mathrm{SO}_{4}\right)$ & 0.05 & 39 & 22 \\
\hline Sulfide (s) & $<0.0002$ & $<0.1$ & $<0.1$ \\
\hline
\end{tabular}

ORGANICS

Priority Pollutants Detected

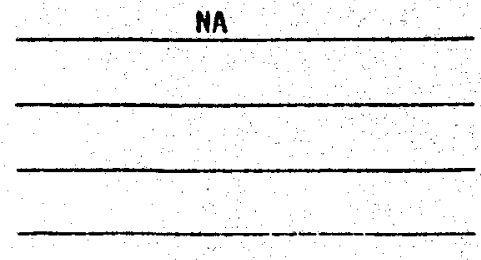

Bioaccumulation Potential

\begin{tabular}{cc} 
ORGANICS \\
Priority Pollutants Detected \\
\hline MA \\
\hline Bioaccumulation Potential \\
\hline
\end{tabular}

Site Owner/Operator: Phillips Petroleum

TRACE ELEMENTS

\begin{tabular}{cc} 
Acid Extract & Neutral Extract \\
\hline$\mu / L$ & $\frac{\mu g / L}{260}$ \\
60 & $<300$ \\
600 & $<5$ \\
$<5$ & $<20$ \\
$<20$ & $<20$ \\
$<20$ & $<1$ \\
$<1$ & $<20$ \\
$<20$ & $<20$ \\
$<20$ &
\end{tabular}

Ant imony (Sb)

Berylllum (Be)

Boron (B)

Copper (Cu)

Lithiun (Li)

Mickel (Ni)

Strontium (Sr)

Zinc (Zn)

$\therefore$

70

$<20$

570

$<70$

400

$<300$

$<500$

$<20$

OTHER PARAMETERS

$\begin{array}{ll}\text { Corrosivity } & \frac{9.3 \mathrm{pH}}{34} \\ \text { Moisture } & \frac{34}{} \\ \text { TSS } & \frac{\mathrm{NA}}{1 . \mathrm{pCl} / \mathrm{g}} \\ \text { Radiun } 226 & \end{array}$


Sample: Sump, Humbolt House Hell

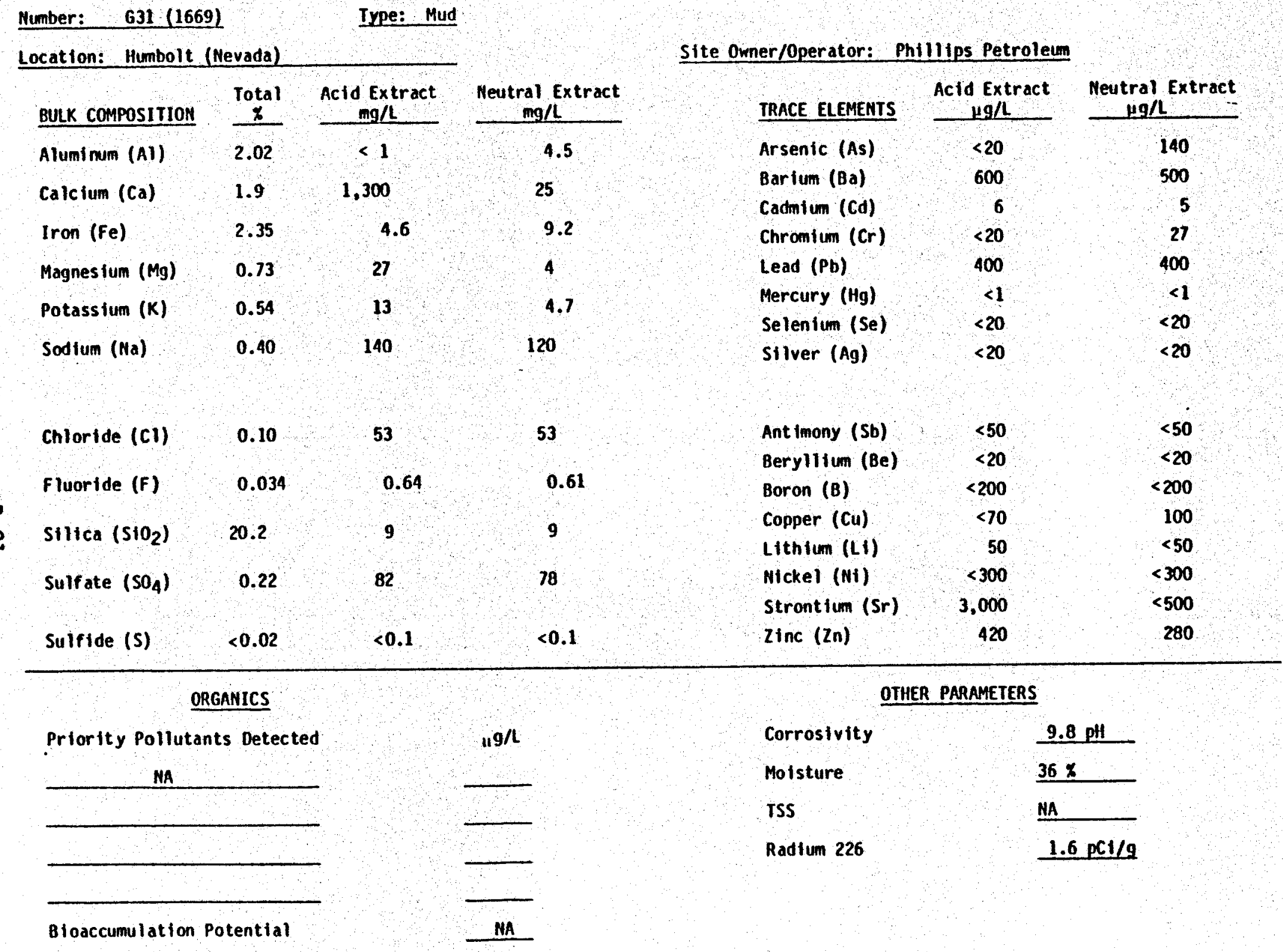




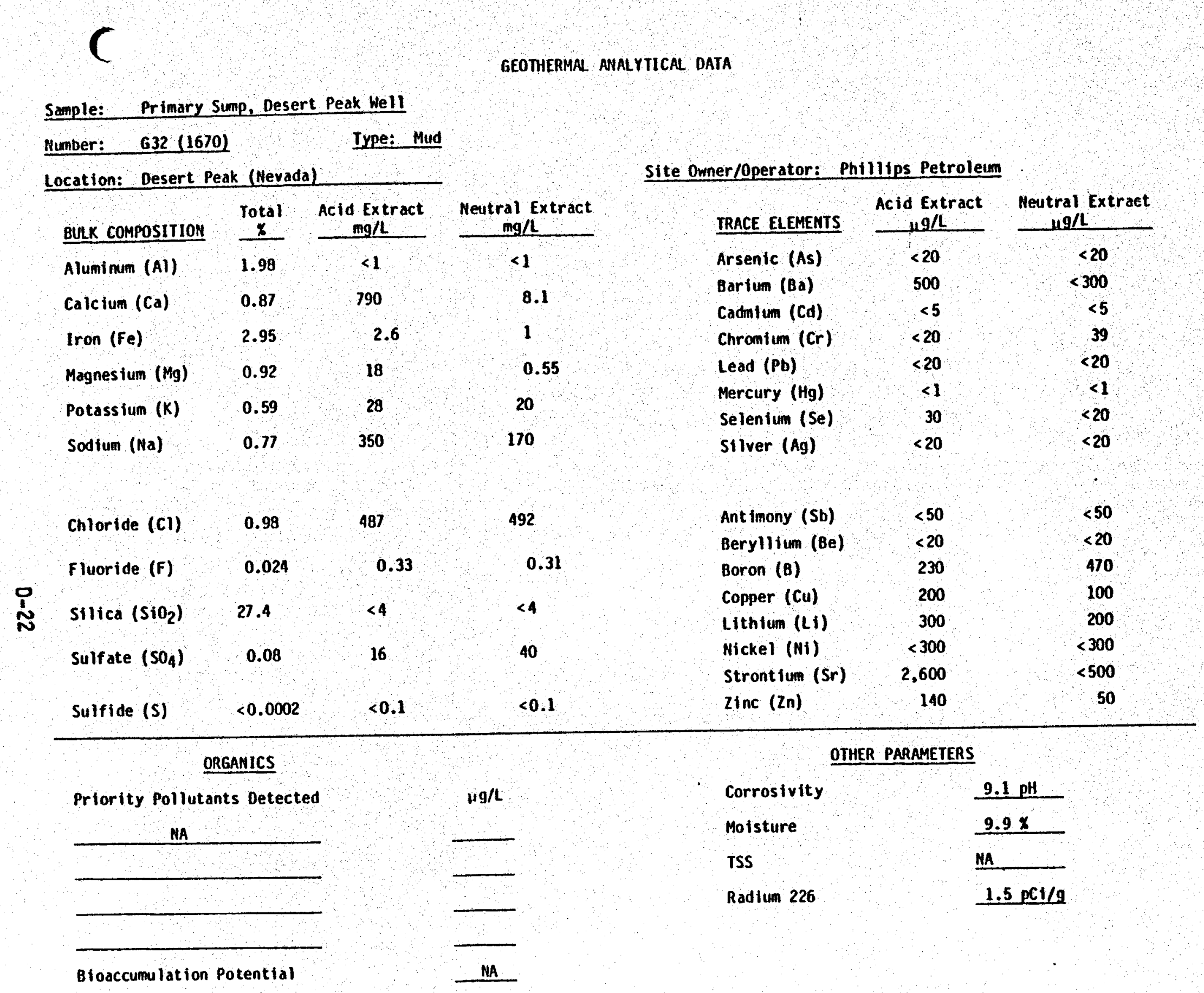


- APPENDIX E

ACID AND BASE/NEUTRAL PRIORITY POLLUTANTS 


\begin{tabular}{|c|c|}
\hline $\begin{array}{l}\text { POLLUTANT ANO } \\
\text { CAS MUMEERS }\end{array}$ & $\begin{array}{c}\text { CONCENTRATION } \\
\Psi Q / 6\end{array}$ \\
\hline \multicolumn{2}{|c|}{ CIMS FRACTION - ACIO COMPOUNOS } \\
\hline \multicolumn{2}{|l|}{$\begin{array}{l}\text { IA. 2-Cnlorophenol } \\
(95-57-8)\end{array}$} \\
\hline \multicolumn{2}{|l|}{$\begin{array}{l}2 A, 2,4-0 \text { ichloro- } \\
\text { pnenol }(120-83-2)\end{array}$} \\
\hline \multicolumn{2}{|l|}{$\begin{array}{l}3 \text { A, } 2,4-0 \text { imethyl- } \\
\text { pheno i (105-67-9) }\end{array}$} \\
\hline \multicolumn{2}{|c|}{$\begin{array}{l}\text { 4A, } 4,6-0 \text { initro-0- (2) } \\
\text { Cresol }(534-52-1)\end{array}$} \\
\hline $\begin{array}{l}\text { 5A, } 2,4-0 \text { initro- } \\
\text { phenol }(51-28-5)\end{array}$ & (2) \\
\hline \multicolumn{2}{|l|}{$\begin{array}{l}6 A, 2-N i t r o p h e n o l \\
(38-75-5)\end{array}$} \\
\hline \multicolumn{2}{|l|}{$\begin{array}{l}7 A_{1} \text { 4-nitrophenol } \\
(100-02-7)\end{array}$} \\
\hline \multicolumn{2}{|l|}{$\begin{array}{l}\text { 8A, D-Chloro-m- } \\
\text { Cresol }(59-50-7)\end{array}$} \\
\hline \multicolumn{2}{|l|}{$\begin{array}{l}\text { sa, Pentaenloro- } \\
\text { pnenol }(97-86-5)\end{array}$} \\
\hline \multicolumn{2}{|l|}{$\begin{array}{l}\text { 10A, Phenol } \\
(108-95-2)\end{array}$} \\
\hline \multicolumn{2}{|l|}{$\begin{array}{l}11 A, 2,4,6-T r i \\
\text { enloro-pnenol } \\
\text { (88-06-2) }\end{array}$} \\
\hline \multicolumn{2}{|c|}{$\begin{array}{l}\text { GCIIS FRACTION - SASE/NEUTRAL } \\
\text { CUMPOUNDS }\end{array}$} \\
\hline \multicolumn{2}{|l|}{$\begin{array}{l}\text { 13. Acenapnenene } \\
(83-32-9)\end{array}$} \\
\hline \multicolumn{2}{|l|}{$\begin{array}{l}\text { 28, Acenaphthy lene } \\
(208-96-8)\end{array}$} \\
\hline \multicolumn{2}{|l|}{$\begin{array}{l}\text { 38, Anthracene } \\
(120-12-7)\end{array}$} \\
\hline $\begin{array}{l}\text { (B, Benzidine } \\
(92-87-5)\end{array}$ & \\
\hline \multicolumn{2}{|l|}{$\begin{array}{l}\text { SB, genzo (a) } \\
\text { Anthracene } \\
\text { (56-55-3) }\end{array}$} \\
\hline \multicolumn{2}{|l|}{$\begin{array}{l}\text { 68. Benzo (a) } \\
\text { Pyrene }(50-32-8)\end{array}$} \\
\hline \multicolumn{2}{|l|}{$\begin{array}{l}78,3,4-8 \text { enzo- } \\
\text { fluor anthene } \\
(205-99-2)\end{array}$} \\
\hline $\begin{array}{l}88, \text { genzo (gni) } \\
\text { Perylene } \\
(191-24-2)\end{array}$ & \\
\hline
\end{tabular}

\begin{tabular}{|cc|}
\hline POLLUTANT AND & CONCENTRATION \\
CAS NUMBERS & $u g / 6$ \\
\hline
\end{tabular}

98, Benzo (k)

Fluor an thene

(207-08-9)

108, o1s (2-Chloro-

ethoxy) Methane

$(111-91.1)$

118, 8 is (2-chloro-

ethyl) E ther

(11)-44-4)

128, B1s (2-Chloro-

isopropyl) Ether

$(39638-32-9)$

138, sis (2-Ethy)-

hexy I) Phthalate

$(117-81-7)$

148,4-8romo-

phenyl Phenyl

Ether (101-55-3)

158, Butyl Benzy?

Phthalate (85-68-71)

168, 2-Chloro-

naphthalene

(91-58-7)

178, 4-chloro-

phenyl Phenyl

Ether (7005-72-3)

188, Chrysene

(218-01-9)

198 , Otbento $(a, h)$

Anthracene

$(53-70-3)$

208, 1,2-0lentoro-

benzene $(95-50-1)$

218, 1,3-0ichloro-

benzene $(541.73-1)$

228, 1,4-0ienloro-

benzene $(106-46-7)$

\section{B, Dimethy \\ Pnthalate}

(131-11-3)

\section{8, Oi-N-8 Buty1}

Phthalate.

(84.74-2)

238, 3,3:-0ten loro-

benzidine

(91-94-1)

\section{8 , Oiethyl}

Phthalate

$(84-66-2)$

$278,2,4$ - oinitro-

zoluene $(121-14-2)$

\begin{tabular}{|c|c|}
\hline $\begin{array}{l}\text { POLLUTANT ANO } \\
\text { CAS NUMBERS }\end{array}$ & $\begin{array}{c}\text { CONCENTRATION } \\
49 / 6\end{array}$ \\
\hline $\begin{array}{l}\text { 288, } 2,6-0 \text { in itro- } \\
\text { toluene }(606-20-2)\end{array}$ & \\
\hline $\begin{array}{l}\text { 298, Di-N-octy) } \\
\text { Phthdiate } \\
\text { (117-84-0) }\end{array}$ & \\
\hline $\begin{array}{l}308,1,2-0 \text { iphenyl- } \\
\text { hydraz ine (as A20- } \\
\text { benzene) (122-66-7) }\end{array}$ & \\
\hline $\begin{array}{l}318, \text { Fluor anthene } \\
(206-44-0)\end{array}$ & \\
\hline $\begin{array}{l}328, \text { luorene } \\
(86-73-7)\end{array}$ & \\
\hline $\begin{array}{l}\text { 338, mexa- } \\
\text { chlorobenzene } \\
(118-71-1)\end{array}$ & \\
\hline $\begin{array}{l}\text { 348, Hexa- } \\
\text { ch lorobutadiene } \\
(87-68-3)\end{array}$ & \\
\hline $\begin{array}{l}\text { 358, Hexach loro- } \\
\text { cyclopentadiene } \\
(77-47-4)\end{array}$ & \\
\hline $\begin{array}{l}368 \text {, Hexachloro- } \\
\text { thane }(67-72-1)\end{array}$ & \\
\hline
\end{tabular}

$$
\begin{aligned}
& 378, \text { indeno } \\
& (1,2,3-c d) \text { Pyrene } \\
& (193-39-5)
\end{aligned}
$$

388, I sophorone
$(78-59-1)$

398, Naphthalene

$(91-20-3)$

408. Mi trobenzene

$(98-95-3)$

\section{8, N-Nitroso \\ dimethylamine \\ $(62-75-9)$}

UTO

428, M-Nitroso-

di-N-Propylanine

$(621-60.7)$

438, M-Nieroso-

di-ohenylamine

$(86-30-6)$

448, Phenanthrene

$(85-01-8)$

458, Pyrene

$(129-00-0)$

$46 \mathrm{~B}, 1,2,4-\operatorname{Tr} 1-$

chlorobenzene

$(120-82+1)$

\section{$E-3$}

